NBER WORKING PAPER SERIES

\title{
COLLATERAL HETEROGENEITY AND MONETARY POLICY TRANSMISSION: EVIDENCE FROM LOANS TO SMES AND LARGE FIRMS
}

\author{
Cecilia R. Caglio \\ R. Matthew Darst \\ Șebnem Kalemli-Özcan \\ Working Paper 28685 \\ http://www.nber.org/papers/w28685 \\ NATIONAL BUREAU OF ECONOMIC RESEARCH \\ 1050 Massachusetts Avenue \\ Cambridge, MA 02138 \\ April 2021, Revised December 2022
}

This paper was circulated before under the title: \Risk-Taking and Monetary Policy Transmission: Evidence from Loans to SMEs and Large Firms." We would like to thank our discussants Olivier Darmouni, Mariassunta Giannetti, Luc Laeven, Yueran Ma, and David Thesmar. We thank Boragan Aruoba, Thomas Dreschel, Mark Gertler, Sasha Indarte, Chen Lian, Peter Karadi, Amir Kermani, Nobu Kiyotaki, Guillermo Ordonez, Pablo Ottonello, Pascal Paul, Jose-Luis Peydro, Adriano Rampini, John Shea, Joseph Stiglitz, Ludwig Straub, Thomas Winberry, participants at seminars at Berkeley, Brown, Columbia, Duke, MIT, NYU, AEA, ECB/CEPR-WEAREIN, NBER EFG, ME and other conference attendees for useful suggestions. We thank Jacob Faber, Jacob Fahringer, Alvaro Silva, and Adam Tucker for their invaluable research assistance. Kalemli-Özcan thanks NSF Grant 2018623 for support. The views in this paper are solely those of the authors and do not reflect the views of the Federal Reserve Board of Governors, or anyone in the Federal Reserve System.

NBER working papers are circulated for discussion and comment purposes. They have not been peer-reviewed or been subject to the review by the NBER Board of Directors that accompanies official NBER publications.

(C) 2021 by Cecilia R. Caglio, R. Matthew Darst, and Șebnem Kalemli-Özcan. All rights reserved. Short sections of text, not to exceed two paragraphs, may be quoted without explicit permission provided that full credit, including $\odot$ notice, is given to the source. 
Collateral Heterogeneity and Monetary Policy Transmission: Evidence from Loans to SMEs and Large Firms

Cecilia R. Caglio, R. Matthew Darst, and Șebnem Kalemli-Özcan

NBER Working Paper No. 28685

April 2021, Revised December 2022

JEL No. E32,E44,E52,G20,O16

\begin{abstract}
Using matched firm-bank level administrative data for the U.S., we document new facts on heterogeneity in firms' financing conditions and quantify its effects on monetary policy transmission. Most private firms in the U.S. are small-medium-size-enterprises (SMEs), whose entire balance sheet debt comes from banks and is collateralized mostly with earnings and intangibles, i.e., their enterprise value. Highly leveraged SMEs' respond to monetary expansions more by increasing their credit demand. They borrow more at lower spreads by pledging earnings-based collateral, whose value increases with monetary expansions. Our results link the bank lending and firm investment channels of monetary policy and show that the impact of policy on investment is stronger in an environment with a large number of small firms, whose borrowing depends on earnings-based constraints.
\end{abstract}

Cecilia R. Caglio

Federal Reserve Board

cecilia.r.caglio@frb.gov

R. Matthew Darst

Federal Reserve Board

1801 K St. NW Suite 6522

Washington, DC 20006

matt.darst@frb.gov
Șebnem Kalemli-Özcan

Department of Economics

University of Maryland

Tydings Hall 4118D

College Park, MD 20742-7211

and CEPR

and also NBER

kalemli@econ.umd.edu 


\section{Introduction}

There is an extensive theoretical literature studying monetary policy transmission in heterogeneous agents macro models focusing on household heterogeneity for consumption channel (e.g Kaplan, Moll, and Violante, 2018; Auclert, 2019; Wong, 2019) and firm heterogeneity for investment channel (e.g Ottonello and Winberry, 2020). This literature models heterogeneity as different financial frictions/credit constraints faced by different types of households/firms, and shows that monetary policy's efficacy in the aggregate economy depends on the distribution of agent types and the constraints they face. Using matched data on firms and banks combined with detailed granular information on loan contracts, we provide systematic evidence on the form of financial constraints firms face and quantify the role that heterogeneity in firm financing plays on monetary policy transmission.

Our paper makes three contributions. First, we jointly analyze the heterogeneous responses of a representative set of private and public firms to monetary policy shocks. Second, we show that highly leveraged private sector firms are more responsive than low leveraged private sector firms to monetary policy shocks. This result reverses for publicly listed firms. Third, we show that the type of pledged collateral matters for the heterogenous responses to monetary policy shocks. Specifically, we show a new mechanism for monetary policy transmission operating through heterogenous collateral rather than common shocks to the financial sector.

We use an administrative data set at the firm-bank-loan-quarter level, containing a more representative set of U.S. firms compared to the existing U.S. firm-level data sets that report firm financing sources. ${ }^{1}$ As shown below in Panel (a) of Figure 1, most of the private firms (red bars) in our data are SMEs with assets less than $\$ 10$ million but almost no SMEs among public firms (blue bars). ${ }^{2}$ Panel (b) shows the firm-size distribution for firms who borrow in syndicated loan markets. ${ }^{3}$ Importantly, the green bars in Panel (b) mimic the blue bars in Panel (a) indicating that the firm-size distribution in the syndicated loan market is almost identical to the distribution of public companies. Hence, the popular data sources for syndicated loan research, LCD Dealscan and the Shared National Credit Registry (SNC) with covenant information, do not contain a representative set of U.S. corporate borrowers. Our data also does not capture the universe of borrowers, but it captures a significant number of SMEs. To be included in our data, a firm must borrow at least 1 million USD from the bank

\footnotetext{
${ }^{1}$ Dinlersoz, Kalemli-Ozcan, Hyatt, and Penciakova (2018) document the selection issues in existing firmlevel data sets such as Compustat, Census-QFR, Kaufman, SBFS and others based on matching these data to Longitudinal Business Dataset (LBD) of the U.S. Census that represents the universe of U.S. firms.

${ }^{2}$ The typical thresholds for being a "small" firm in the U.S. studies are based on firms with assets less than $\$ 50$ or $\$ 100$ million in Compustat or QFR, corresponding to bottom 10-15th percentile. This problem is due to low coverage of truly small firms in those non-representative datasets.

${ }^{3}$ Only 0.8 percent of the firms in our sample borrow in syndicated loan markets.
} 
holding companies supervised by the Federal Reserve. By comparison, to be included in SNC, firms need to borrow a minimum of 20 million USD from at least 3 of the same banks.

Figure 1: Firm Size Distribution: Private vs. Public Firms and Syndicated Loan Borrowers
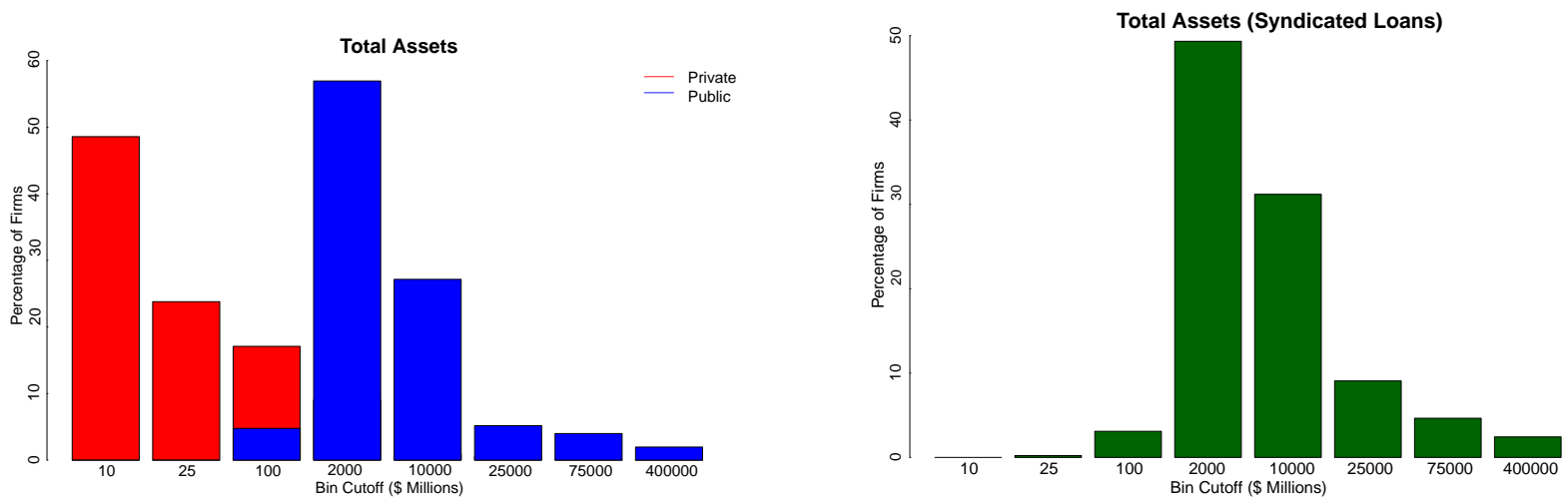

Note: The figure shows firm size distribution based on assets, for all private firms (red bars) and public firms (blue bars), in Panel (a), and for firms who borrow in syndicated loan markets, Panel (b).

Our data come from quarterly bank stress tests (FR Y-14Q report) carried out by the Federal Reserve as part of the Comprehensive Capital Analysis and Review (CCAR) process for bank holding companies, and U.S. Intermediate Holding Companies of foreign banking organizations. ${ }^{4}$ The data covers 70 percent of total Corporate and Industrial (C\&I) loans made to U.S. firms between Q3:2012 to Q4:2019. The firms in the FR Y-14Q account for a large part of total U.S. corporate sector debt and U.S. gross output. Figure 2 shows that the aggregate dollar value of liabilities in the FR Y-14Q (from firms' balance sheets including bonds and loans) is 64 percent of the aggregate dollar value of non-financial business debt liabilities from the Financial Accounts of the United States during the sample period (first green bar). The second bar shows the that FR Y-14Q firms represent almost 80 percent of U.S. output measured as total gross output from the Bureau of Economic Analysis. ${ }^{5}$

It is also important to note that SMEs, which constitute most of the FR Y-14Q firms, borrow entirely from banks with almost no presence in the bond market, a fact that is missed in aggregate data. Figure 3 plots financing sources for the non-financial business

\footnotetext{
${ }^{4}$ The data covers systemically important banks, defined as all financial institutions with $\$ 50$ billion or more in total consolidated assets. The asset threshold has changed to $\$ 100$ billion end of 2019 . The appendix provides the list of the reporting financial institutions.

${ }^{5}$ The publicly listed firms in FR Y-14Q data account for 31 percent of the U.S. corporate debt. Not all publicly listed firms borrow from banks and hence are not covered in FR Y-14Q data. The share of U.S. corporate debt attributable to the universe of publicly listed firms is 48 percent. The publicly listed firms only account for 44 percent of aggregate U.S. gross output, 26 percent of aggregate U.S. employment once the foreign output and employment is cleaned from the data. See Dinlersoz, Kalemli-Ozcan, Hyatt, and Penciakova (2018).
} 
Figure 2: Coverage of Y-14 Data: Aggregate U.S. Corporate Debt and Output

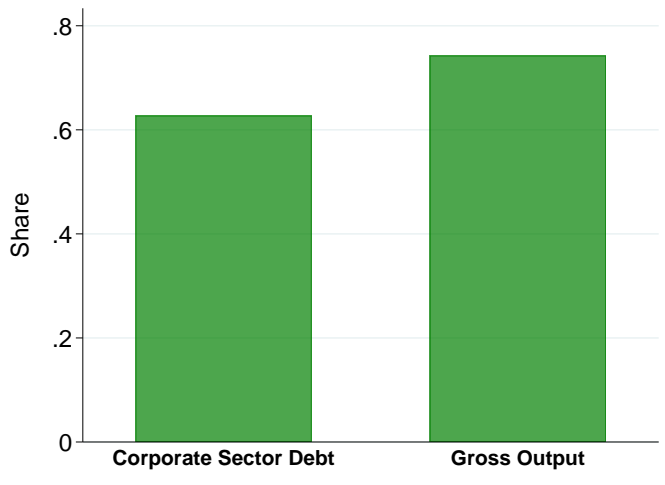

Note: The first bar is corporate sector debt in FR Y-14Q data as a share of total non-financial business debt liabilities from the U.S. Financial Accounts. The second bar shows gross output in FR Y-14Q as a share of BEA U.S. gross output.

sector from the Financial Accounts of the United States. Panel (a) shows the debt share for publicly listed and large private firms (such as $\mathrm{C}$ and $\mathrm{S}$ corporations), known as "non-financial corporate businesses," an aggregate that is extensively used by researchers. The share of bank finance, shown by the line "Bank Debt" is small for these companies-around 20 percent on average. Panel (b) plots the "non-financial businesses" aggregate which includes other small private firms. ${ }^{6}$ In this panel, the bank-finance share goes up to 30 percent. In addition, the share of market debt declines sharply. Although bank financing overall plays a small role in the aggregate data, the difference between the two panels hints at the importance of bank financing for SMEs.

Comparing the aggregate data, which are dominated by large public firms, to firm balance sheet data in the FR-Y 14Q allows us to draw a drastically different picture. Figure 4 plots the share of bank debt on private firm balance sheets in the FR Y-14Q. For large private firms, defined as firms in the upper quartile of the asset distribution, the FR Y-14Q data matches the narrative of the aggregate data in Figure 3 (a); bank lending accounts for only 22 percent of their financing. However, financing for the remaining private firms-small and medium size categories-is almost exclusively bank-based. Private firms below the 75th percentile of the asset distribution have assets less than $\$ 43$ million and revenue less than $\$ 86$ million. The median firm has $\$ 12$ million in assets and $\$ 28$ million in sales, making the typical private

\footnotetext{
${ }^{6}$ The private firms included in the "non-financial non corporate" series (L.104 in the Financial Accounts of the U.S.) comprise partnerships, limited liability companies and sole-proprietorships. In the Financial Accounts of the United States, detailed liabilities for private firms, in both non-financial non-corporate and non-financial corporate categories, are not built from the bottom up using firm-level tax records. Total liabilities are based on aggregates from Statistics of Income (SOI) from IRS. The share of each liability type is estimated using other data sources (for example, Call Reports for the total of bank deposits) reported by lenders.
} 
Figure 3: Non-financial Firms' Financing in the Financial Accounts of the United States

(a) Non-financial Corporate Businesses

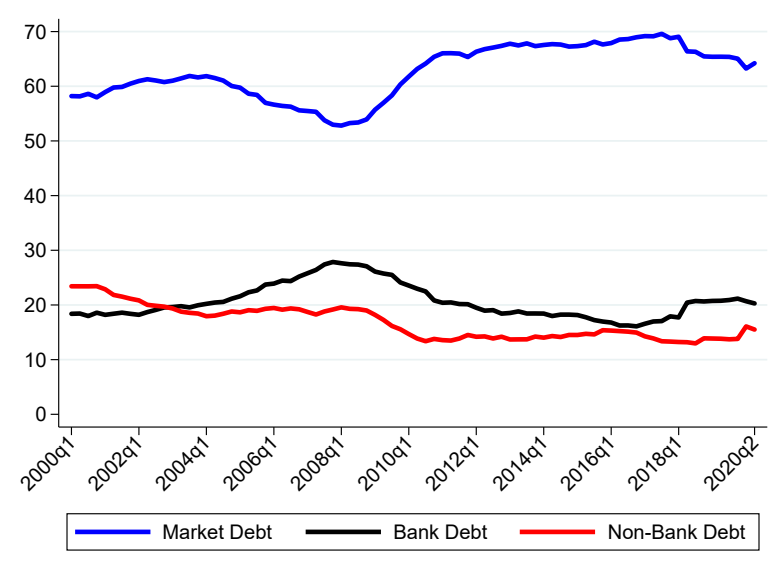

(b) Non-financial Businesses

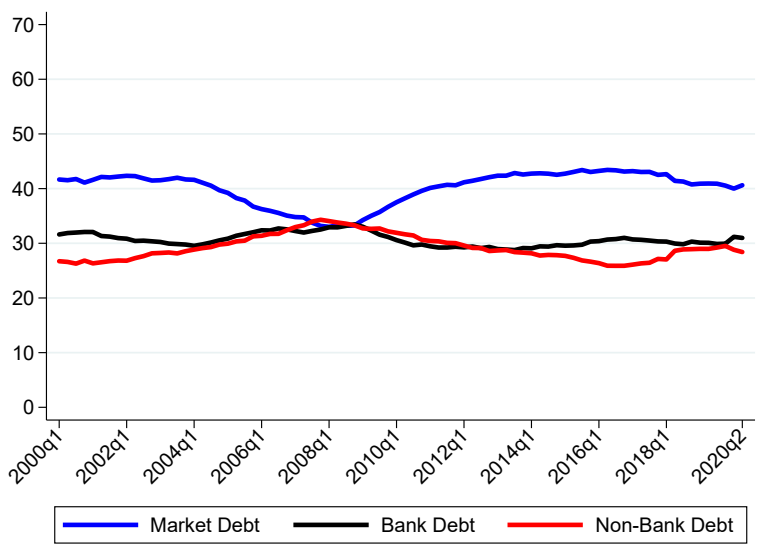

Note: The panel (a) represents the debt share from different lenders for the "non-financial corporate businesses" in the U.S. The panel (b) represents similar debt share for all "non-financial businesses" in the U.S. The "Bank Debt" include Corporate and Industrial (C\&I) loans and non-residential mortgages held by banks. "Non-bank Debt" includes, among others, syndicated loans held by non-banks, non-residential mortgages held by non-banks, and finance company loans. "Market Debt" comprises corporate bonds, commercial paper, and industrial revenue bonds. Source: Financial Accounts of the United States.

firm in the U.S. an SME. ${ }^{7}$

Understanding the borrowing patterns and loan terms of bank-financed SMEs is instrumental for understanding monetary policy transmission in the U.S., as SMEs account for bulk of aggregate U.S. economic activity and face heterogeneous financial frictions. Gertler and Karadi (2015) argue that monetary policy can change the cost of credit through movements in risk spreads. Therefore, monetary policy may impact loan terms for firms with high default risk differently than firms with low default risk. Small firms are in general associated with higher default risk.

Monetary policy transmission can operate through two complementary mechanisms. On the one hand, as shown by Ottonello and Winberry (2020), firms with high default risk (high leverage firms) might respond less than low default risk firms to monetary expansions due to relatively higher marginal costs inclusive of default risk, even though expansions reduce the cost of credit for everyone. Alternatively, monetary expansions relax financial constraints for small and low net worth borrowers relatively more as shown by Bernanke

\footnotetext{
${ }^{7}$ The U.S. Census Bureau, with no data on firm financing, defines SMEs as firms with less than 500 employees. Based on this employment definition, the Small Business Administration (SBA) reports that SMEs account for 99.8 percent of all U.S. firms, 52 percent of private sector employment and 50 percent of private sector gross output in the U.S. There is not a well-established asset and/or revenue cut-off to define SMEs in the U.S. across all the industries. Since FR Y-14Q data does not cover employment, we follow the OECD definition of SMEs as firms with assets less than $\$ 10$ million, and/or revenue less than $\$ 50$ million. Based on sales and asset definition, SMEs also account over 50 percent of the U.S. gross output.
} 
Figure 4: Share of Bank Debt in Non-financial Private Firms' Financing

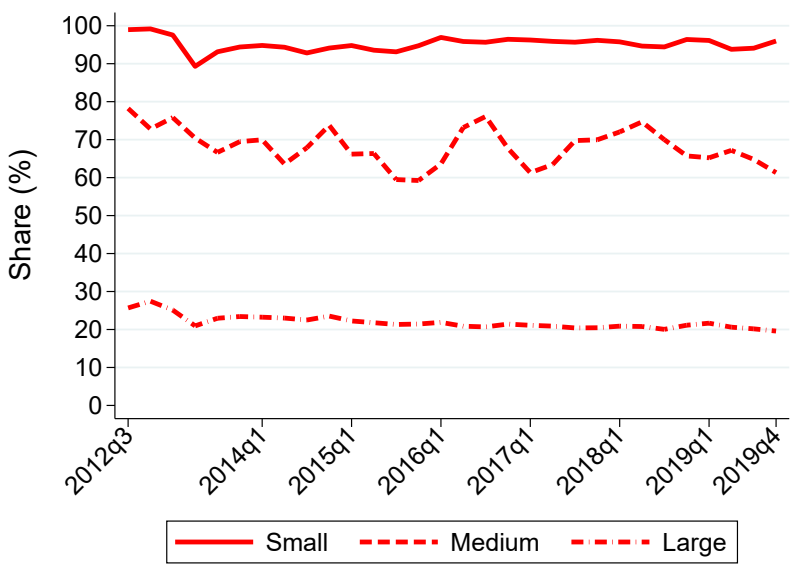

Note: The figure plots the median loan utilization as share of total balance sheet debt (loans and bonds) for various points in the asset-size distribution among private borrowers. See Figure 21 for median loan commitment. Source: FR-Y14Q H.1

and Gertler (1989); Gertler and Gilchrist (1994), leading to financial acceleration in the aggregate economy (Bernanke, Gertler, and Gilchrist, 1996). The ultimate aggregate effect is an empirical question that depends on the heterogeneity in the data both in terms of size and default risk. We show that firm size, leverage, and default risk cannot be mapped one-to-one. Instead, firm size can be mapped to the type of collateral pledged, which has an effect on leverage and default risk. The loan-level pricing and pledged collateral information in FR Y-14Q allow us to zoom in on the financial friction that expansionary monetary policy relaxes for different types of firms. ${ }^{8}$

We regress two main credit outcome variables - cost and amount of credit - on measures of firm, bank, and collateral heterogeneity interacted with monetary policy shocks, identified as surprises using the high frequency even-study methodology as in Gertler and Karadi (2015). The regressions assess the impact of a monetary policy surprise in quarter $q$ on the credit outcomes for different firms and banks using different collateral from quarter $q$ to $q+1$. We separate firms and banks into treatment and control groups based on their characteristics observed before the monetary policy shock happens. We include bank $\times$ quarter and firm $\times$ quarter fixed effects separately to pin down the relative importance of credit demand versus supply-borrowing vs lending channels of monetary policy. Regressions with bank $\times$ quarter fixed effects use cross-firm variation in firm credit demand from a single bank.

\footnotetext{
${ }^{8}$ It is very rare to observe both the loan-level interest rates and collateral in credit registries. The only other credit registry with this information, to the best of our knowledge is from an emerging market, Turkey, see di Giovanni, Kalemli-Özcan, Ulu, and Baskaya (2021).
} 
Regressions with firm $\times$ quarter fixed effects use variation in credit supply from multiple banks lending to the same firm. Finally, to ease concerns of non-random matching between firms and banks, we use variation from multiple loans between a given firm-bank pair by employing firm $\times$ bank $\times$ quarter fixed effects-within-firm-bank variation-where credit outcomes are driven simultaneously by changes in loan demand and supply for a given firm-bank relationship.

We show that SMEs with higher "ex-ante" leverage (before the expansion) borrow more at a higher cost during monetary expansions. The higher costs are driven by increased credit demand and not by higher default risk. Even if higher leverage predicts default as in Ottonello and Winberry (2020), the type of collateral used by SMEs flattens the supply curve for funds during monetary expansions, lowering default risk. SMEs mostly borrow against collateral whose value is inextricably tied to firm operations, intangibles, and hence enterprise continuation values rather than collateral whose value is market or re-sale based such as fixed assets and real estate. SMEs that pledge earnings and operations-based collateral access more credit at lower rates during normal times, and this access to credit effect is amplified during monetary expansions. Expansionary monetary policy stimulates aggregate demand and firms' earnings, which reduces highly leveraged SME default risk by reducing the spreads on loans backed by collateral tied to those earnings and operations. Therefore, the higher cost borrowing costs paid by leveraged SMEs relative to others stems from increased credit demand rather than default risk as the value of earning and operations-based collateral rises in response to a monetary expansion.

Our results are consistent with the notion that expansionary shocks increase borrowing capacity when earnings-based constraints are the dominant form of collateral as modeled in Drechsel (2022). Lian and Ma (2020) and Ivashina, Laeven, and Moral-Benito (2022) show that a large amount of borrowing is secured by earnings in a sample of publicly listed firms in the U.S. and a larger sample of firms in Peru, respectively. By making use of "pledged" collateral for a representative set of U.S. firms, we show that earnings-based constraints are even more important for SMEs and central to monetary policy transmission in the U.S.

The results are driven by leveraged SMEs. We find the opposite result for leveraged large firms, who respond less to monetary expansions, consistent with the empirical application in Ottonello and Winberry (2020) that uses data on public firms. We also investigate the effect of monetary policy transmission on real outcomes - namely investment, sales, and inventories - providing consistent evidence with our credit growth results. Finally, we show that our results are not driven by the bank-lending channel per se where bank heterogeneity drives differential credit supply growth. We find the opposite: highly leveraged banks lend less to private firms and SMEs during monetary policy expansions.

We proceed as follows. Section 2 summarizes the literature. Section 3 describes the 
data. Section 4 presents the benchmark results on the transmission of monetary policy to credit outcomes based on firm leverage. Section 5 provides evidence on heterogeneous collateral backing firm leverage and further explains the intuition of the benchmark results by documenting the effect of monetary expansions on different collateral constraints. Section 6 presents robustness ruling-out alternative stories, most importantly the role of bank heterogeneity. Section 7 presents additional analysis such as dynamics effects; the impact of monetary policy on investment, sales, and inventories as a function of financial frictions; presents an aggregation exercise; and discusses a primer on the theoretical mechanism. Section 8 concludes.

\section{Literature}

Our paper contributes to several strands of literature. First, we contribute to the literature that studies the impact of monetary policy focusing on borrower and lending financial frictions. Bernanke and Gertler (1989) and Bernanke, Gertler, and Gilchrist (1996) study the financial accelerator channel in representative agent new Keynesian models. Expansionary monetary policy improves net worth and reduces agency frictions, which allows low net worth (risky) borrowers to increase their access to finance. Alternatively, low interest rates reduce funding costs and the incentive to produce risky projects, which may reduce credit rationing (e.g Stiglitz and Weiss, 1981). Our contribution to this literature is, for the first time, capture all these theoretical channels with granular data.

A second but related literature argues that low interest rates encourage supply-side lending. For example, low interest rates may induce "search-for-yield" behavior and reallocate capital toward risky borrowers (e.g Rajan, 2005). Dell'Ariccia, Laeven, and Suarez (2017) find that high capital-low leverage bank portfolios become more risky-higher share of risky loans-when interest rates fall. Moreover, these banks charge lower spreads on syndicated loans during expansionary policy (e.g Paligorova and Santos, 2017). Our results on the bank credit supply side are consistent with these papers focusing on the U.S. There are other papers, focusing on other countries and finding the opposite result (e.g Jiménez, Ongena, Peydró, and Saurina, 2014). Our contribution to this literature, thanks to our firm-bank matched data and granular loan-level data, is to simultaneously investigate credit supply and demand factors, focusing on heterogeneous financial frictions. We show that credit growth is driven by smaller firms with high leverage during monetary expansions.

Third, our paper relates to the literature studying the interaction between firm heterogeneity in terms of firm size, age, and leverage, and monetary policy transmission (e.g Gertler and Gilchrist, 1994; Jeenas, 2019; Cloyne, Ferreira, Froemel, and Surico, 2022; 
Ottonello and Winberry, 2020). The empirical results from this literature are mixed and based on different U.S. firm samples. Our representative sample of U.S. firms allows us to pin down the type of firm heterogeneity that matters for policy transmission and document the mapping from firm heterogeneity, in terms of size, age, leverage etc., to firm-level financial frictions. Our results are fully consistent both with Gertler and Gilchrist (1994) and Ottonello and Winberry (2020). The former shows the importance of smaller firms for policy transmission, while the latter shows that a high degree of leverage inhibits transmission due to higher default risk, showing that this is the case in a sample of public firms. We find similar results for highly leveraged public firms (see Appendix Table 21), but highly leveraged private firms respond more to monetary policy shocks, not less as public firms. We show that highly leveraged private firms are almost all SMEs. Hence, our results are consistent with Gertler and Gilchrist (1994). Our contribution to this literature is to show that smaller firms are more important for the transmission as in Gertler and Gilchrist (1994), since monetary policy has a direct impact on the collateral these firms pledge. As these firms use more earnings-based collateral, monetary expansions increase the value of that collateral, lowering the spreads on SMEs' loans and increasing their borrowing capacity. We provide an interpretation of our results from the lens of the Ottonello and Winberry (2020) model in our last section.

Fourth, our paper contributes to the literature highlighting the importance of financial contracts in transmitting shocks to the aggregate economy. In the models developed by Kiyotaki and Moore (1997) and Kiyotaki, Moore, and Zhang (2021), entrepreneurs borrow against fixed assets and real estate (trees). If a firm uses these assets as collateral and defaults, then lenders confiscate the assets and sell them to other buyers. Hence, the market or liquidation value of the asset determines its collateral value to lenders and final borrowing capacity. In these models, entrepreneurs use collateral to generate output (fruit) but cannot borrow against that output. However, in our data, SME loans are most frequently secured by accounts receivable and inventory (AR\&I) collateral and blanket liens. The common property of AR\&I and blanket lien collateral is that both their value derives from firm operations, that is they are current fruit. In particular, firm sales combine ideas, intangible capital, marketing of products, etc., which are embedded in the value of the fruit they produce and become capitalized and pledgeable on the balance sheet as AR\&I and blanket liens. We find that monetary policy not only changes the relative price of fixed assets as in traditional models, it also impacts firms' ability to produce its own assets that are used as collateral (fruit). The framework of Benmelech and Bergman (2012) can rationalize our findings. They argue that monetary policy, through the general equilibrium impact on aggregate demand, increases firm sales (and accounts receivable), which increases borrowing capacity. Our contribution to this literature is to provide evidence on how monetary policy shocks relax or tighten different 
constraints differently interacting with the pricing of loans.

We also contribute to the new empirical literature that draws a distinction between debt secured by assets (asset-based loans) and debt tied to firm cash-flows and earnings (earnings-based or going concern debt) (e.g Lian and Ma, 2020; Kermani and Ma, 2020). Our contribution here is to draw on brand-new granular data on pledged collateral, which allows us to show that the firm itself creates its own collateral value through production rather than purchasing it as it does with land or machines. We show that the inability to separate the liquidation value of AR\&I from going-concern value embedded in blanket liens is particularly important for SMEs who do not have large amounts of tangible fixed assets to pledge. We call AR\&I and blanket lien collateral, 'earnings and operations-based' collateral, though we do not need to group them for our results. Our results on monetary policy transmission show that these two types of collateral, AR\&I and blanket liens, work exactly the same because their values derive from firm operations and continuation values.

Finally, we contribute to the literature arguing that monetary policy can be less effective/ powerful during recessions and/or during a low interest rate environment given low returns to savers (e.g Tenreyro and Thwaites, 2016; Kiyotaki, Moore, and Zhang, 2021). Our contribution to this literature is to show a new mechanism that depends on the size distribution of the firms and collateral heterogeneity, that can make monetary policy powerful even in a low interest rate environment.

\section{Data}

We present a brief description of our data here and provide details in the Data Appendix.

\subsection{What is a private firm and a public firm?}

For each quarter, we define private firms in FR Y-14Q data as those that cannot be matched to COMPUSTAT either via 6 -digit CUSIP or via tax ID (EIN). ${ }^{9}$

Large public firms generally report consolidated financial statements to banks. To avoid double counting of financial variables for the subsidiaries, we match our data to the Bloomberg Corporate Structure Database with EIN, when possible, or name matching. We roll up loans to subsidiaries to their parent company when banks report parent company rather than subsidiary financial information. In these cases, treating subsidiaries as separate "firms"

\footnotetext{
${ }^{9}$ We allow for initial public offerings (IPOs) and leveraged buy-outs (LBOs). In particular, we match FR Y-14 data to COMPUSTAT quarter-by-quarter. Therefore, a private firm undertaking an IPO will move from private to public in that quarter. That said, the number of firms that move between samples during our time period is very small.
} 
would introduce errors in firm size and other distributional cuts of the data. ${ }^{10}$ The final data has 3,798,946 loan-level observations for 155,589 unique U.S. corporations, where $153 \mathrm{~K}$ are private firms, covering all sectors of the U.S. economy.

\subsection{Descriptive Statistics}

\subsubsection{Banks}

Table 1 shows descriptive statistics for the 39 banks subject to CCAR. Total (0.882) and short-term (0.727) bank leverage during our sample period are lower than before the financial crises due to various post-crisis regulatory reforms. The last two rows report bank charge offs, which are non-performing loan losses on banks' balance sheets. The average bank charge-off is about about $\$ 22$ million and represents on average 6 percent of a given loan, again showing that non-performing loan issues were not big during this period.

\subsubsection{Firm and Loan Level Outcomes}

Tables 2, 3, and 4 provide summary statistics for a number of firm balance sheet variables and loan-level information on pricing, collateral and maturity. These summary statistics suggest that financial constraints are tighter for private than public firms.

Table 2 shows that the average private firm has $\$ 137$ million in assets compared to $\$ 10$ billion for the average public firm. The average private borrower is more leveraged in terms of short term debt and has higher sales growth and investment than the average public firm. The average private firm does not have access to other financing sources aside from banks. They have almost no outstanding bonds, nor any other form of security outstanding-for example, commercial paper, privately placed or expired bonds. By contrast, a large part of publicly listed firms have current bonds outstanding (34 percent) and almost all have issued some form of security (99 percent).

Table 3 compares firms along the size distribution and leverage dimensions. SMEs have average assets of $\$ 18.5$ million compared to the average large firm-defined by the upper quartile of the asset distribution-with $\$ 1.8$ billion, and have slightly higher sales growth. Large firms are more leveraged than SMEs. In general, sales growth and investment are similar among high and low leveraged firms, for all firms and for SMEs. The difference in debt maturity across firm size is minimal. SME loans are on average 3.5 years compared

\footnotetext{
${ }^{10}$ Relying on the tax ID without the full corporate structure to identify unique firms in the data is also problematic because banks frequently report identical tax ids for both parent companies and their subsidiaries. This results in different balance sheet information for the same tax id because the balance sheet information is attributed to two distinct firms. For robustness in all of our regressions, we remove the loan amounts to identified subsidiaries and find that the results are qualitatively the same.
} 
Table 1: Summary Statistics - Bank Level

\begin{tabular}{lccccc}
\hline & $(1)$ & $(2)$ & $(3)$ & $(4)$ & $(5)$ \\
& 1st Qu. & Median & Mean & 3rd Qu & SD \\
\hline Liabilities-to-Assets & 0.868 & 0.884 & 0.882 & 0.897 & 0.024 \\
Short-Term-Debt-to-Assets & 0.690 & 0.769 & 0.727 & 0.808 & 0.14 \\
Charge-off $b$ (millions) & 0 & 10.415 & 22.618 & 29.295 & 38.887 \\
Charge-off/Loan $_{b}$ & 0 & 2.645 & 5.857 & 7.347 & 10.351 \\
\hline
\end{tabular}

Note: This table reports bank level statistics for the 39 banks that report loan and borrower information on the FR Y-14Q used in the analysis. Liabilities-to-assets use total liabilities and the short-term-debt-to-assets ratio uses only financial debt liabilities due within one year. Charge-off is the cumulative dollar value of all net charge-offs across all outstanding loans on a bank's balance sheet. Charge-off/loan is the ratio of the cumulative charge off associated with a given loan over the remaining committed value of the loan. Source Y9C and FR Y-14Q H.1.

to 2.7 years for large firms. Among SMEs, loan maturity for high versus low leverage firms is comparable, at 3.9 versus 3.2 years. Moreover, the type of loan-credit line versus term loan-does not vary across firm size. $62 \%$ of SME loans are credit lines compared to $64 \%$ for large firms. Low leveraged firms have slightly more credit lines.

Finally, Table 4 shows that private borrowers pay higher interest rates than public borrowers on their loans, despite almost always pledging collateral. Accounts receivable and inventory and blanket liens are the most common forms of collateral used by private firms.

\section{Empirical Analysis: The Role of Leverage}

In this section, we map monetary policy surprise shocks to firm-bank and loan-level credit outcomes to understand the role that firm, bank, and collateral heterogeneity play, in terms of financial frictions in monetary policy transmission.

\subsection{Measuring Monetary Policy Surprises}

We estimate monetary policy surprises, denoted with ' $\mathrm{MP}$ ', based on high frequency identification in Gertler and Karadi (2015). We compute the surprise component of a policy announcement at the monthly level as:

$$
M P_{t}^{m}=\gamma_{t} \times\left(\mathrm{ffr}_{t}^{m}-\mathrm{ffr}_{t-\Delta t}^{m}\right) ; \gamma_{t} \equiv \frac{\tau^{n}}{\tau^{n}-\tau^{d}}
$$

where $m$ denotes the month, $\mathrm{ffr}_{t}$ is the implied Fed Funds Rate from a Federal Funds future contract at time $t$, and the adjustment factor, $\gamma_{t}$, controls for the timing of the announcement within the month. $\tau^{n}$ is the number of days in the month of the FOMC meeting, and $\tau^{d}$ 
Table 2: Summary Statistics - Firm Level

\begin{tabular}{lccc}
\hline & $(1)$ & $(2)$ & $(3)$ \\
& All Firms & Private Firms & Public Firms \\
\hline $\begin{array}{l}\text { Levels (millions \$) } \\
\text { Fixed Assets }\end{array}$ & 169.575 & 38.673 & 6298.168 \\
Capital Expenditures & 650.642 & 20.965 & 19611.266 \\
Total Assets & 419.795 & 137.144 & 10012.128 \\
EBITDA & 60.842 & 17.764 & 1518.326 \\
& & & \\
Ratios & & & \\
Liabilities-to-Assets & 0.626 & 0.627 & 0.582 \\
Account Receivable-to-Sales & 0.117 & 0.092 & 0.957 \\
Inventory-to-Sales & 0.112 & 0.102 & 0.433 \\
Short-Term-Debt-to-Assets & 0.140 & 0.144 & 0.014 \\
$\Delta$ Fixed Assets/Fixed Assets & 0.133 & 0.134 & 0.093 \\
Sales Growth & 0.348 & 0.350 & 0.313 \\
Share of firms issuing bond & 0.012 & 0.006 & 0.337 \\
Share of firms issuing securities & 0.060 & 0.040 & 0.990 \\
\hline
\end{tabular}

Note: This table reports mean of firm balance sheet and income statement variables by firm type. The sample includes 155,600 U.S. firms for the period 2013-2019, excluding financial and government owned firms such as utilities, and 2,043,008 firm-quarter pairs. All dollar amounts in the table are expressed in millions. Liabilities-to-Assets is defined as total liabilities over total assets while short-term-debt-to-assets is defined as total short-term financial debt over total assets. $\Delta$ fixed assets is defined as the annual change in fixed assets. Sales growth is defined at the annual percentage change in total sales. Private firm accounting and income statement data come from the FR Y-14 H.1 Schedule and are winsorized at 4 percent; public firm data are from the S\&P Compustat database and are winsorized at 1 percent. Refer to Table A.1 in the Appendix for additional variable definitions.

is the day of the FOMC meeting. ${ }^{11}$ It is common to use a combination of current month, 3-month ahead and 6-month ahead futures. Our data begin in 2012Q4 when policy rates were operating at the zero-lower bound (ZLB). Thus, the size of the raw surprises from 1 month or 3 month futures are small, and insufficient to identify the impact of monetary policy on credit outcomes. To address this issue, we use the 6-month ahead and 9-month ahead futures contract following the work by Miranda-Agrippino and Rey (2020) and Kalemli-Ozcan (2019), who both study international spillovers of U.S. monetary policy during the ZLB. ${ }^{12}$ To extract the surprise component, we measure price changes of the futures 15 minutes before and 45 minutes after the FOMC.

We follow Ottonello and Winberry (2020) and convert the surprise series to a quarterly

\footnotetext{
${ }^{11}$ Note that the multiplier becomes quite large for FOMC events at the end of the month. This could magnify measurement errors. When the adjustment factor is greater than 4, we follow the literature and replace the adjustment factor with the rate change in the following month federal futures contract without a multiplier.

${ }^{12}$ If we use price changes in 2-year treasuries, we obtain similar results. These results are available upon request.
} 
Table 3: Summary Statistics by Firm Size and Leverage - Firm Level

\begin{tabular}{|c|c|c|c|c|c|c|}
\hline & \multirow{3}{*}{$\begin{array}{c}(1) \\
\text { All SME }\end{array}$} & \multirow{3}{*}{$\begin{array}{c}(2) \\
\text { Large }\end{array}$} & \multicolumn{2}{|c|}{ All Firms } & \multicolumn{2}{|c|}{ SME } \\
\hline & & & $(3)$ & $(4)$ & $(5)$ & $(6)$ \\
\hline & & & High Leverage & Low Leverage & High Leverage & Low Leverage \\
\hline \multicolumn{7}{|l|}{ Levels (millions \$) } \\
\hline Fixed Assets & 6.647 & 449.472 & 147.622 & 168.480 & 7.404 & 5.922 \\
\hline Capital Expenditures & 2.693 & 496.268 & 153.077 & 209.865 & 1.919 & 2.832 \\
\hline Total Assets & 18.527 & 1086.888 & 357.883 & 426.988 & 17.711 & 17.990 \\
\hline EBITDA & 2.543 & 157.381 & 56.009 & 65.165 & 2.437 & 2.354 \\
\hline Maturity & 3.549 & 2.766 & 3.308 & 2.852 & 3.940 & 3.240 \\
\hline \multicolumn{7}{|l|}{ Ratios } \\
\hline Liabilities-to-Assets & 0.614 & 0.643 & 0.784 & 0.492 & 0.794 & 0.474 \\
\hline Account Receivable-to-Sales & 0.100 & 0.147 & 0.087 & 0.125 & 0.072 & 0.115 \\
\hline Inventory-to-Sales & 0.105 & 0.125 & 0.120 & 0.100 & 0.114 & 0.094 \\
\hline Short-Term-Debt-to-Assets & 0.136 & 0.144 & 0.247 & 0.045 & 0.241 & 0.049 \\
\hline$\Delta$ Fixed Assets/Fixed Assets & 0.141 & 0.102 & 0.108 & 0.123 & 0.097 & 0.132 \\
\hline Sales Growth & 0.363 & 0.318 & 0.361 & 0.371 & 0.373 & 0.373 \\
\hline Credit Lines & 0.625 & 0.645 & 0.587 & 0.664 & 0.557 & 0.671 \\
\hline \multicolumn{7}{|l|}{ Observations } \\
\hline Firms & 116157 & 55843 & 88882 & 105325 & 62936 & 78350 \\
\hline Firm-Quarter & 1267683 & 766629 & 884048 & 1080736 & 526547 & 691637 \\
\hline
\end{tabular}

Note: This table reports mean of firm balance sheet and income statement variables by firm size. See Table 2 for the definition of variables. 'SME' are firms with sales less than 50 million on average throughout the sample. 'High Leverage' firms those with leverage greater than the median leverage in the sample on average. Refer to Table A.1 in the Appendix for additional variable definitions.

Table 4: Summary Statistics - Loan Level

\begin{tabular}{lccc}
\hline & $(1)$ & $(2)$ & $(3)$ \\
& All Firms & Private Firms & Public Firms \\
\hline Interest Rate (Percent) & 2.80 & 3.00 & 1.90 \\
Collateral: Fixed assets and real estate & 0.243 & 0.266 & 0.14 \\
Collateral: Cash and marketable sec & 0.024 & 0.022 & 0.034 \\
Collateral: Act. receiv. and inventory & 0.284 & 0.308 & 0.172 \\
Collateral: Blanket lien and other & 0.304 & 0.322 & 0.224 \\
Collateralized & 0.854 & 0.916 & 0.567 \\
Maturity (in years) & 3.079 & 3.1 & 2.994 \\
\hline
\end{tabular}

Note: This table reports loan-level mean of each variable. The collateral categories are the fraction of total loans collateralized by each respective category. For example, among all firms, 24 percent of all loans are collateralized by fixed assets and real estate. Collateralized is the fraction off all loans that are collateralized by any collateral category. For example, among all firms, 85.4 percent of loans are collateralized.

variable using a weighted moving average of the surprises based on the number of days in the quarter after the surprise has occurred. We plot these in Figure 5 below. This ensures that the surprises are weighted according to the amount of time banks and firms have to react to the changes. 
Figure 5: Quarterly Monetary Policy Surprises

(a) 6 and 9 Month MP Surprises at the ZLB

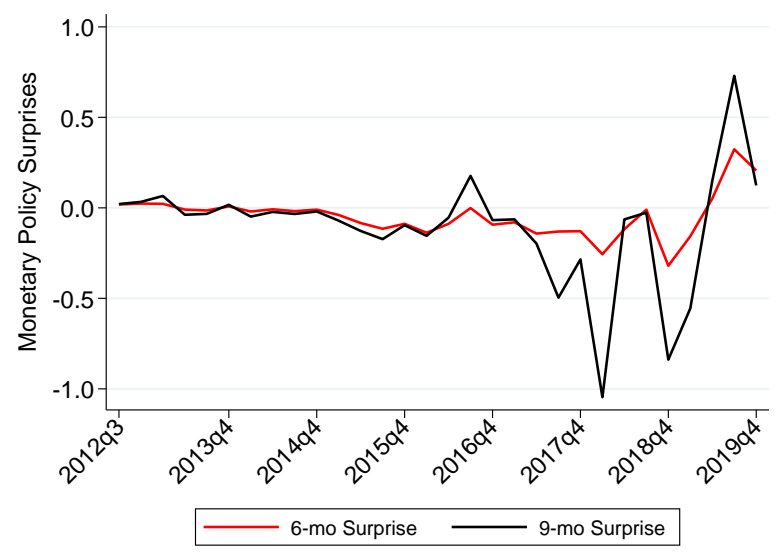

(b) Historical MP Surprises and Moving Averages

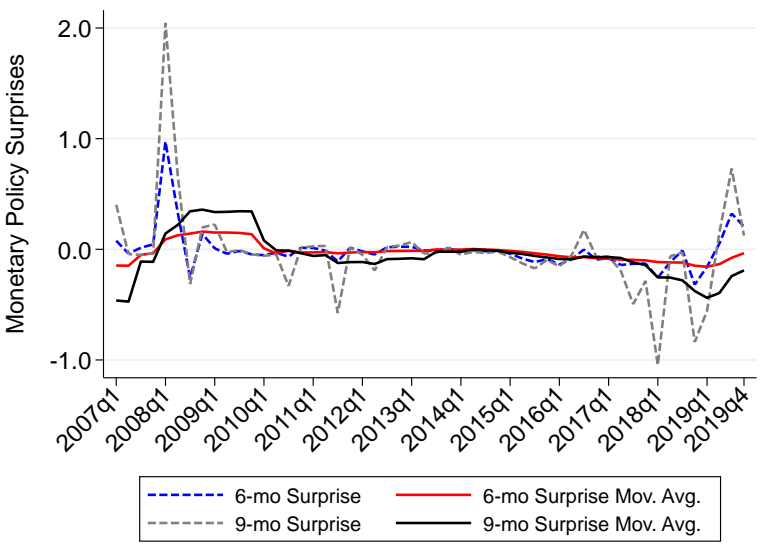

Note: This figure plots monetary policy surprises in percentage points following the quarterly aggregation of Ottonello and Winberry (2020). Panel (a) plots the surprise component of the 6-mo and 9-mo feds funds future during our period and panel (b) plots the historical-moving average of the same shocks to compare the size of the shocks during the ZLB period vs before.

When we analyse the dynamic impulse responses of credit outcomes to policy surprises via local projections, we use these quarterly surprises shown in Figure 5 directly. For the OLS regressions that deliver average effects, we construct 4 and 8-quarter moving averages of the quarterly surprises. The moving average representation allows for monetary policy to have delayed and persistent effects. For example, Romer and Romer (2004) find that monetary policy transmits to real variables and prices with a several quarters' delay and has persistent effects over twenty quarters in the future. Hence, a moving average representation of the quarterly surprises links the surprises to the intermediate-term stance of the monetary policy. Both the surprises and the policy stance were largely expansionary during our sample period.

\subsection{Firm Leverage and Risk of Default}

We measure firm leverage in the standard way as ratio of debt to assets. We use both short-term debt and total debt. We use leverage as a firm-level financial friction measure, similar to Ottonello and Winberry (2020), as firm leverage is assumed to be a good proxy for firm default risk. Consistent with this assumption, we show in Table 5 that firm leverage predicts default, both unconditionally and conditional on having non-performing loans, both for private and public firms. These results are robust to the way we measure firm leverage: based on short-term debt to total assets or total debt to total assets. For the default risk predictability regressions, we measure firm leverage every quarter, but for our main monetary policy transmission regressions, we use time-invariant "ex-ante" firm leverage. 
Table 5: Firm Leverage and Default

\begin{tabular}{|c|c|c|c|c|c|c|c|c|c|}
\hline \multirow{4}{*}{ 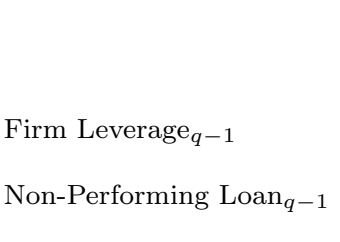 } & \multicolumn{9}{|c|}{ Default Probability } \\
\hline & \multicolumn{3}{|c|}{ All Firms } & \multicolumn{3}{|c|}{ Private Firms } & \multicolumn{3}{|c|}{ Public Firms } \\
\hline & $\begin{array}{c}0.0448^{* * *} \\
(0.0028)\end{array}$ & & $\begin{array}{c}0.0496^{* * *} \\
(0.0074)\end{array}$ & $\begin{array}{c}0.0412^{* * *} \\
(0.0027)\end{array}$ & & $\begin{array}{c}0.0367^{* * *} \\
(0.0063)\end{array}$ & $\begin{array}{c}0.1044^{* * *} \\
(0.0214)\end{array}$ & & $\begin{array}{c}0.1266^{* * *} \\
(0.0327)\end{array}$ \\
\hline & & $\begin{array}{c}0.0181^{* * *} \\
(0.0049)\end{array}$ & $\begin{array}{c}0.0175^{* *} \\
(0.0048)\end{array}$ & & $\begin{array}{c}0.0525^{* * *} \\
(0.0115)\end{array}$ & $\begin{array}{c}0.0519^{* * *} \\
(0.0114)\end{array}$ & & $\begin{array}{c}0.0002 \\
(0.0038)\end{array}$ & $\begin{array}{l}-0.0007 \\
(0.0038)\end{array}$ \\
\hline Observations & 1656049 & 535836 & 535836 & 1454694 & 415830 & 415830 & 201355 & 120006 & 120006 \\
\hline Adjusted $R^{2}$ & 0.601 & 0.810 & 0.811 & 0.601 & 0.822 & 0.822 & 0.576 & 0.663 & 0.673 \\
\hline Firm F.E. & Yes & Yes & Yes & Yes & Yes & Yes & Yes & Yes & Yes \\
\hline Quarter F.E. & Yes & Yes & Yes & Yes & Yes & Yes & Yes & Yes & Yes \\
\hline
\end{tabular}

Note: This table reports the results of regressing firms $i$ 's loan-weighted default probability in quarter $q$ on its lagged leverage ratio and a non-performing loan dummy. The loan-weighted default probability is the each bank's one-year ahead default probability for firm $i$ weighted by the loan commitment amount for each bank. The non-performing loan dummy is equal to 1 if a firm has any non-performing loans in the prior period. The results are reported for all firms in the sample, and for the private and public firm samples. All regressions contain firm and quarter fixed effects.

\subsection{Firm-Bank Level Regressions: Benchmark Results}

We start by aggregating all loans between a firm and a bank to the pair-quarter level. The two dependent variables are the credit amount borrowed/lent and interest rate paid by firm $f$ to bank $b$ in a quarter $q$. We run the below regressions to understand how monetary policy transmits to these credit outcomes differently through high versus low leverage firms. 'High Leverage Firm' is a dummy equal to one for firms with leverage in the first quarter of the sample (or average leverage) higher than the median leverage, and zero otherwise.

Why should monetary policy affect high and low leverage firms differentially? As we show above, firm leverage is a good proxy for firm default risk, which is informative for borrowing capacity and credit costs. Also, recall that high and low leverage firms have similar sales and investment growth rates. Hence, the impact of monetary policy on the credit demand of high and low leverage firms should be similar unless monetary policy has a differential impact on firm borrowing costs.

The baseline regression is the following:

$$
\begin{aligned}
\log \sum_{l \in \mathcal{L}(f, b, q)} Y_{f, b, q}(l) & =\alpha_{f, b}+\alpha_{b, q}+\alpha_{s, q} \\
& +\kappa\left(\text { High Leverage } \text { Firm }_{f} \times \frac{1}{N} \sum_{k=0}^{N} \mathrm{MP}_{q-k}\right)+\vartheta_{f, b, q}
\end{aligned}
$$

where $\log \sum_{l \in \mathcal{L}(f, b, q)} Y_{f, b, q}(l)$, is either the total loan amount, $\mathcal{L}$, or weighted average of one plus the loan interest rate, $\left(1+i_{f, b, q}\right)$ for a given bank-firm pair, $(b, f)$, and quarter, $(q)$. Loan interest rates between pairs are computed as a weighted average based on the dollar value 
of the loan because different loans may have different rates for a given bank-firm pair. $\alpha_{f, b}$ is the firm $\times$ bank fixed effect and $\alpha_{b, q}$ is the bank $\times$ quarter fixed effect. These soak up the cross-sectional variation in banking relationships and time variation in differential bank credit supply. $N$ captures either a 4 or 8 -quarter moving average, indexed by $k$. On the left-hand side, we consider the log of total loans to allow expansionary monetary policy to create new firm entry into the credit market. A $\Delta \log$ formulation (credit growth for a given firm) would restrict the analysis to existing firms throughout the sample, which misses an important monetary policy objective. The interest rate contains a risk-free rate, which is LIBOR for over 80 percent of the loans, plus an idiosyncratic credit spread. Time fixed effects absorb the common risk-free rate and direct effect of monetary policy. Hence, all variation comes from the idiosyncratic risk spread in the interest rate variable.

We use sector $\times$ quarter fixed effects, $\alpha_{s, q}$. This is important given the large differences in loan outcomes across sectors. Figure 6 shows the average and total dollar amounts committed to each two-digit NAICS sector in Panels (a) and (b) respectively. The Figure shows that, on average, the largest loans are committed to firms in the utilities; information; and mining, quarrying, and oil and gas extraction sectors. By contrast, aggregate commitments are largest for firms in the manufacturing and wholesale and retail trade sectors, indicating that there are many small loans to a large number of businesses in these sectors. There are also substantial differences in collateral types across sectors, even within the public and private firms, as shown in Tables 22 and 23. Although blanket lien and AR\&I remain to be most used collateral across all sectors on average, there are important differences. For example, about $60 \%$ of loans to private accommodation and food services firms are secured by blanket liens compared to just 10\% for retail trade. By contrast, AR\&I collateral accounts for nearly $70 \%$ of secured loans to private retail trade firms and only $10 \%$ for accommodation and food service firms. Real estate and fixed assets account for just over $10 \%$ of the collateral in these industries used to secure loans, compared to nearly $40 \%$ of collateralized borrowing for firms in the real estate, transportation, and warehousing industries.

Table 6 shows the benchmark results for quantity (columns (1)-(3)) and price (columns (4)-(6)). The top panel uses MP surprises based on 6 month futures and the bottom uses the surprises based on 9 month futures. Regardless of the futures maturity, columns (1) and (4) show that a surprise monetary expansion leads more leveraged firms to borrow more at higher spreads, consistent with improved borrowing capacity and increased credit demand. ${ }^{13}$ The interpretation that the effects are demand driven is supported by two observations. First,

\footnotetext{
${ }^{13}$ Similar results are obtained using total loan utilization rather than commitments; the coefficient is -0.7852 and a std. deviation of 0.175 on the interaction term of high leverage and MP surprises-6mo in all U.S. firms sample.
} 
Figure 6: Loan Commitments by Sector

Panel (a): Mean Exposure by Sector

Mining, Quarrying, and Oil and Gas Extraction

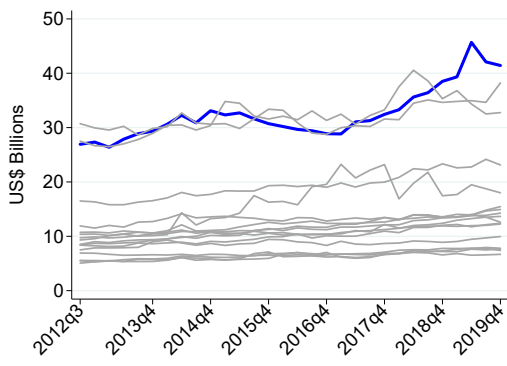

Information

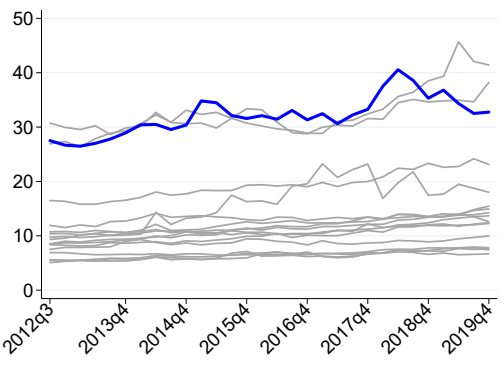

Utilities

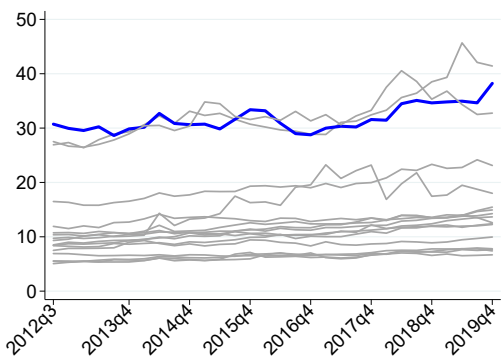

Panel (b): Total Exposure by Sector

Manufacturing

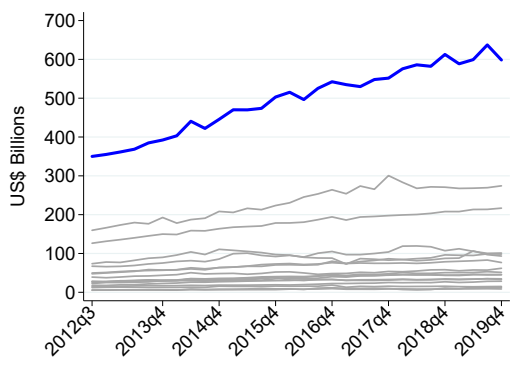

Retail Trade

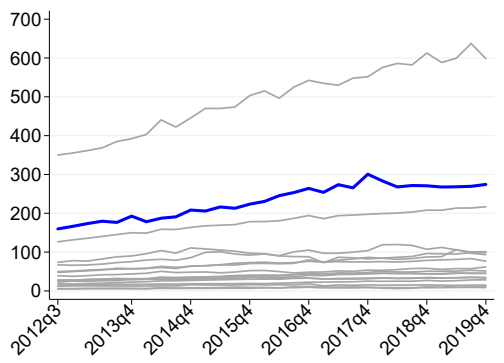

Wholesale Trading

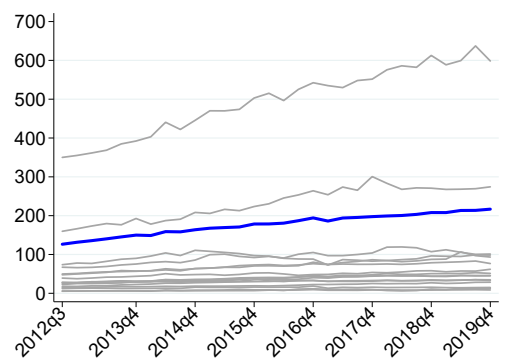

Note: Panel (a) plots the mean dollar value of loan commitments by the borrower's primary 2-digit NAICS industry. Panel (b) plots the total dollar value of committed loans by the borrower's primary 2-digit NAICS industry. Source: FR-Y14Q H.1.

prices and quantities move in the same rather than opposite directions. Second, including bank $\times$ quarter fixed effects absorbs supply side variation and allows variation in credit demand to drive the results. Although monetary expansions reduce spreads for all firms, the higher cost of credit for high leverage firms could reflect their higher default risk together with their higher credit demand. We use collateral data in the next section to sort this out and show that monetary expansions reduce the spreads on high leverage firms more since these firms' collateral is more valuable under expansions. Hence, price results in column (4) are driven by higher credit demand of high leveraged firms.

The aggregate results in columns (1) and (4) are entirely driven by private rather than public borrowers. Columns (3) and (6) show that credit demand and spreads among public firms do not respond differently to monetary policy surprises based on their leverage. ${ }^{14}$

\footnotetext{
${ }^{14}$ When we use total leverage than leveraged public firms respond less to monetary expansions, consistent with Ottonello and Winberry (2020). There is no differential response in prices. See Appendix Table 21.
} 
Table 6: Monetary Policy and Credit Outcomes: The Role of Firm Leverage

\begin{tabular}{|c|c|c|c|c|c|c|}
\hline \multirow[b]{2}{*}{ 6-Months Monetary Policy Surprises } & \multicolumn{3}{|c|}{ Quantity: Log(Loan) } & \multicolumn{3}{|c|}{ Price: $\log (1+i)$} \\
\hline & $\begin{array}{l}(1) \\
\text { All }\end{array}$ & $\begin{array}{c}(2) \\
\text { Private }\end{array}$ & $\begin{array}{c}(3) \\
\text { Public }\end{array}$ & $\begin{array}{l}(4) \\
\text { All }\end{array}$ & $\begin{array}{c}(5) \\
\text { Private }\end{array}$ & $\begin{array}{c}(6) \\
\text { Public }\end{array}$ \\
\hline High Leverage Firm $\times$ MP Surprise $_{q}$ & $\begin{array}{c}-0.1802^{* *} \\
(0.0586)\end{array}$ & $\begin{array}{c}-0.4924^{* * *} \\
(0.0814)\end{array}$ & $\begin{array}{c}0.0935 \\
(0.2081)\end{array}$ & $\begin{array}{c}-0.0132^{* * *} \\
(0.0017)\end{array}$ & $\begin{array}{c}-0.0173^{* * *} \\
(0.0019)\end{array}$ & $\begin{array}{c}0.0083^{+} \\
(0.0042)\end{array}$ \\
\hline Observations & 2452947 & 2133263 & 319675 & 1944630 & 1731254 & 213342 \\
\hline Adjusted $R^{2}$ & 0.945 & 0.939 & 0.839 & 0.847 & 0.853 & 0.751 \\
\hline \multicolumn{7}{|l|}{ 9-Months Monetary Policy Surprises } \\
\hline High Leverage Firm $\times$ MP Surprise $_{q}$ & $\begin{array}{c}-0.0566^{* *} \\
(0.0193)\end{array}$ & $\begin{array}{c}-0.1483^{* * *} \\
(0.0237)\end{array}$ & $\begin{array}{c}0.0210 \\
(0.0741)\end{array}$ & $\begin{array}{c}-0.0062^{* * *} \\
(0.0005)\end{array}$ & $\begin{array}{c}-0.0076^{* * *} \\
(0.0006)\end{array}$ & $\begin{array}{c}0.0042^{*} \\
(0.0016)\end{array}$ \\
\hline Observations & 2452947 & 2133263 & 319675 & 1944630 & 1731254 & 213342 \\
\hline Adjusted $R^{2}$ & 0.945 & 0.939 & 0.839 & 0.847 & 0.853 & 0.751 \\
\hline Bank $\times$ Firm F.E. & Yes & Yes & Yes & Yes & Yes & Yes \\
\hline Bank × Quarter F.E. & Yes & Yes & Yes & Yes & Yes & Yes \\
\hline Sector $\times$ Quarter F.E. & Yes & Yes & Yes & Yes & Yes & Yes \\
\hline
\end{tabular}

Note: ${ }^{+} p<0.1,{ }^{*} p<0.05,{ }^{* *} p<0.01,{ }^{* * *} p<0.001$. This table presents OLS estimates of (2) at the bank-firm level at a quarterly frequency. Interest rates are weighted by the loan shares for a given firm-bank. Double-clustered standard errors by firm and quarter are reported in parentheses.

To confirm the results are driven by highly leveraged SMEs rather than unobserved time-varying differences between private and public firms, we rerun regression equation (2) on the full sample of FR Y-14Q firms and cut the sample on size and leverage. Specifically, we define a time-invariant SME dummy equal to one if the average firm's revenue over the sample is less than $\$ 50$ million. The high leverage dummy is defined as before. The specification also includes the triple interaction term of high leverage, SME, and the monetary policy surprise. We use surprises based on 6 month futures.

Table 7 shows the results. The last row in the table shows that our baseline result is indeed driven by leveraged SMEs. The significance of the interaction term of leverage and monetary policy disappears moving from column (1) to (3) and from (4) to (6). Column (6) shows that leveraged SMEs pay even higher spreads than leveraged large firms during monetary expansions, indicative of leveraged SME higher credit demand. Interestingly, the coefficient of the interaction term between the SME dummy and monetary policy surprise indicates that SMEs borrow and pay less than large firms as a result of monetary policy easing, which suggests SMEs face tighter borrowing constraints and demand less credit than large firms.

This difference between size and leverage is hard to pin down in non-representative 
datasets when the measure for small firms is the bottom 10th percentile coverig firms with 50-100 million in sales. With under-representation of small firms, one cannot pick up the facts we show: that is small firms are more financially constrained and large firms are more leveraged. Whether or not leverage acts as a financial constraint differentially on different size of firms depends on the shock. As shown in Table 8, we have extensive variation in size, where our smallest firms have assets less than 1 million and sales less than 5 million. There is no simple mapping between size and leverage linked to financial frictions and monetary policy shocks: small firms are more financially constrained even under monetary expansions, whereas leveraged firms are not. Monetary expansions seem to be easing the financial constraints of highly leveraged firms even if they are small.

Overall, the results show that expansionary monetary policy has a particular effect on the borrowing capacity and credit demand of leveraged SMEs that is not ex-ante obvious. In Section 5 below, we dig deeper into the exact form of financial friction that explains the channel behind why leveraged SMEs credit demand and borrowing capacity expands in spite of higher default risk.

Table 7: Monetary Policy and Credit Outcomes: The Role of Leverage and Size

\begin{tabular}{|c|c|c|c|c|c|c|}
\hline & \multicolumn{3}{|c|}{ Quantity } & \multicolumn{3}{|c|}{ Price } \\
\hline & $\begin{array}{c}(1) \\
\log (\operatorname{Loan})\end{array}$ & $\begin{array}{c}(2) \\
\log (\operatorname{Loan})\end{array}$ & $\begin{array}{c}(3) \\
\log (\operatorname{Loan})\end{array}$ & $\begin{array}{c}(4) \\
\log (1+i)\end{array}$ & $\begin{array}{c}(5) \\
\log (1+i)\end{array}$ & $\begin{array}{c}(6) \\
\log (1+i)\end{array}$ \\
\hline High Leverage Firm $\times$ MP Surprise $_{q}$ & $\begin{array}{c}-0.1802^{* *} \\
(0.0586)\end{array}$ & & $\begin{array}{c}0.0343 \\
(0.0853)\end{array}$ & $\begin{array}{c}-0.0133^{* * *} \\
(0.0019)\end{array}$ & & $\begin{array}{l}-0.0024 \\
(0.0019)\end{array}$ \\
\hline SME $\times$ MP Surprise $_{q}$ & & $\begin{array}{c}0.6424^{* * *} \\
(0.1079)\end{array}$ & $\begin{array}{c}1.0410^{* * *} \\
(0.1736)\end{array}$ & & $\begin{array}{c}0.0119^{* * *} \\
(0.0011)\end{array}$ & $\begin{array}{c}0.0334^{* * *} \\
(0.0029)\end{array}$ \\
\hline High Leverage Firm $\times$ SME $\times$ MP Surprise $_{q}$ & & & $\begin{array}{c}-0.6223^{* * *} \\
(0.1299)\end{array}$ & & & $\begin{array}{c}-0.0294^{* * *} \\
(0.0031)\end{array}$ \\
\hline Observations & 2452947 & 2452947 & 2452947 & 1950654 & 1950654 & 1950654 \\
\hline Adjusted $R^{2}$ & 0.945 & 0.945 & 0.945 & 0.845 & 0.845 & 0.845 \\
\hline Bank $\times$ Firm F.E. & Yes & Yes & Yes & Yes & Yes & Yes \\
\hline Bank × Quarter F.E. & Yes & Yes & Yes & Yes & Yes & Yes \\
\hline Sector $\times$ Quarter F.E. & Yes & Yes & Yes & Yes & Yes & Yes \\
\hline
\end{tabular}

Note: ${ }^{+} p<0.1,{ }^{*} p<0.05,{ }^{* *} p<0.01,{ }^{* * *} p<0.001$. This table presents results for the OLS regressions for bank-firm pairs using quarterly data for the all sample. The dependent variable in columns (1)-(3) is the natural logarithm of the total committed loan amount for a bank-firm pair; the dependent variable in columns (4)-(6) is the natural logarithm of one plus the nominal interest rate weighted for loan shares for a given bank-firm pair. $S M E$ is a dummy indicating whether a firm is a SME (less than 50 millions in net sales) or non-SME. Double-clustered standard errors by firm and time are reported in parentheses.

\section{The Role of Earnings \& Operations-Based Collateral}

The results so far show that expansionary monetary policy surprises increase the borrowing capacity of leveraged SMEs, in spite of their higher default risk. Following Kiyotaki and 
Table 8: Firms Sales and Assets by Decile

\begin{tabular}{lcc}
\hline Decile & Assets & Sales \\
\hline 1 & 1.239 & 5.938 \\
2 & 3.500 & 13.997 \\
3 & 6.233 & 23.861 \\
4 & 10.223 & 38.630 \\
5 & 16.801 & 63.394 \\
6 & 29.622 & 108.453 \\
7 & 63.784 & 209.839 \\
8 & 210.982 & 472.919 \\
9 & 1081.471 & 1488.500 \\
10 & 69431 & 63404 \\
\hline $\begin{array}{l}\text { Note: } \\
\text { and sales by table shows firm decile. }\end{array}$ \\
are in millions of dollars.
\end{tabular}

Moore (1997), many papers show that financial frictions via collateral constraints impact monetary policy transmission and can amplify business cycle fluctuations. In this class of models, due to default risk, firm borrowing is collateralized by a fraction of the resale value of the capital stock in the next period. Hence, in these models, risk shows up through the use of collateral rather than borrowing costs through spreads. Monetary policy changes the resale value of assets that generates changes in firm borrowing capacity.

The collateral information reported in the FR Y-14 data allows us to test the impact of monetary policy on credit growth and pricing via relaxation/tightening of collateral constraints based on the different types of collateral pledged to obtain a loan. We start by showing descriptive statistics on collateral that form the basis of the new facts we document in this paper on U.S. credit markets.

\subsection{Descriptive Statistics on Pledged Collateral}

Figure 7 plots the share of loans secured by some form of collateral broken out by private and public borrowers. Slightly more than 90 percent of all private loans are collateralized (red solid line), compared to roughly 50 percent for public borrowers (blue solid line). Remarkably, 95 percent of all loans to smaller private firms are collateralized (red dotted line), while small public firms collaterize up to 70 percent of the loans (blue dotted line). Hence pledging collateral can be mapped one to one to firm size indicating small firms are more financially 
constrained than large firms. ${ }^{15}$

Figure 7: Share of Loans that are Collateralized: Public vs. Private

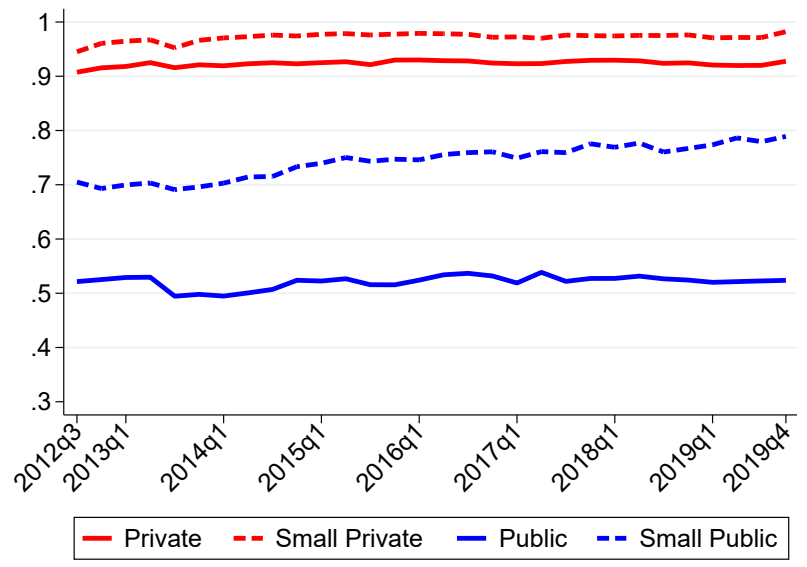

Note: The figure reports the share of loans that are collateralized, for private (red) and public (blue) borrowers. The solid line is the share of total loans collateralized for the private and public firm samples. The dashed line represents the share of total loans that are collateralized for firms in the 25th percentile of the asset distribution (small), for both the private and public firm sample. Source: FR Y-14Q H.1

The FR-Y14Q data also contains granular information about the type of collateral used to secure a loan. Specifically, the banks report six collateral categories: real estate; fixed assets; cash and marketable securities; accounts receivable and inventory (AR\&I); blanket liens, and other. Figure 8 shows loan shares (by value) secured by the different collateral types. ${ }^{16}$ There are several remarkable features to highlight. First, real estate collateral (in red) is important only for the smallest private borrowers and virtually absent among public borrowers. Second, fixed assets (light green) as a fraction of all collateralized loans is not an important source of collateral and may only reflect leases (Eisfeldt and Rampini, 2008). Third, AR\&I (dark green) and blanket liens (light blue) are equally important collateral sources across the firm size distribution except for the medium and large public companies. In fact AR\&I and blanket lien collateral are the most important collateral for all private firms and the smallest public firms. Finally, unsecured borrowing (dark blue) increases monotonically across firm size and dominates the borrowing pattern of large public firms. Appendix Figure 22 zooms in on SMEs and shows the same collateral break down. As expected, the figure mimics the pledged collateral by small private and medium private firms, and shows that the most important form of collateral used to borrow by financially constrained SMEs are AR\&I and blanket liens.

\footnotetext{
${ }^{15}$ Gopinath, Kalemli-Ozcan, Karabarbounis, and Villegas-Sanchez (2017) show evidence for similar size dependent collateral constraints for European firms.

${ }^{16}$ Appendix Figure 23 shows the same figure based on number of loans instead of value.
} 
Figure 8: Collateral Types Across Firm Size Distribution by Public and Private Firms

Small Private

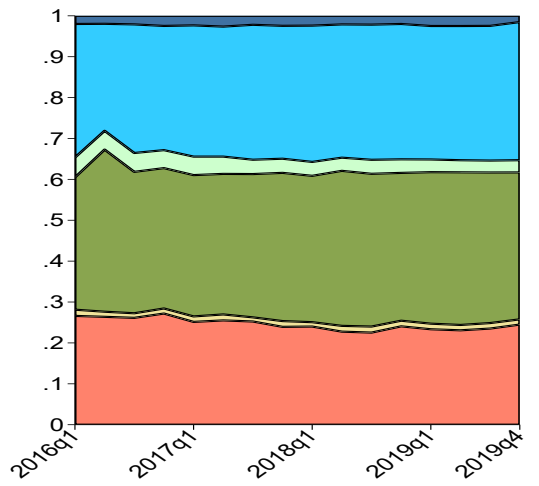

Small Public

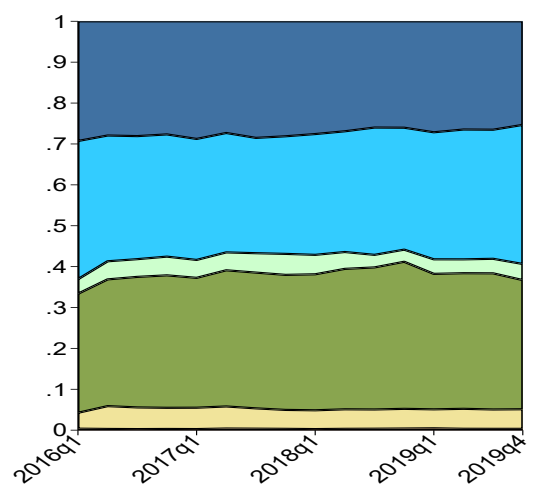

Medium Private

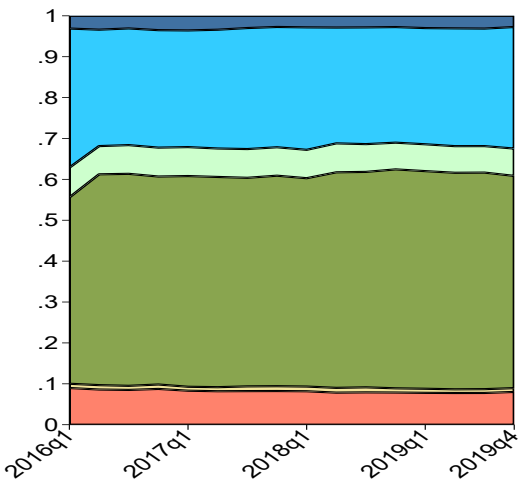

Medium Public

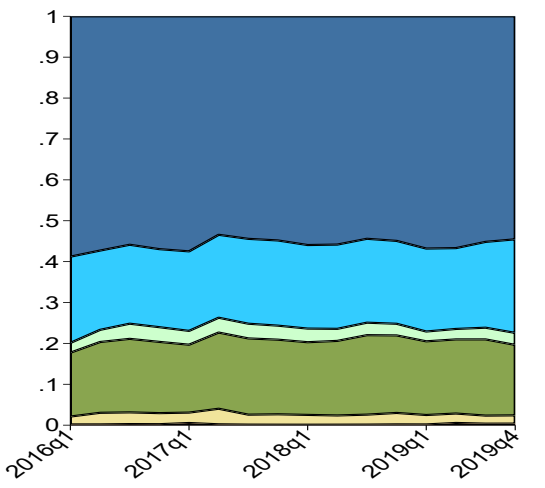

\section{$\square$ Unsecured \\ Blanket Lien + Other \\ $\square$ Fixed Assets \\ $\square$ Accounts Receivable and Inventory \\ $\square$ Cash and Marketable Securities \\ $\square$ Real Estate}

Large Private

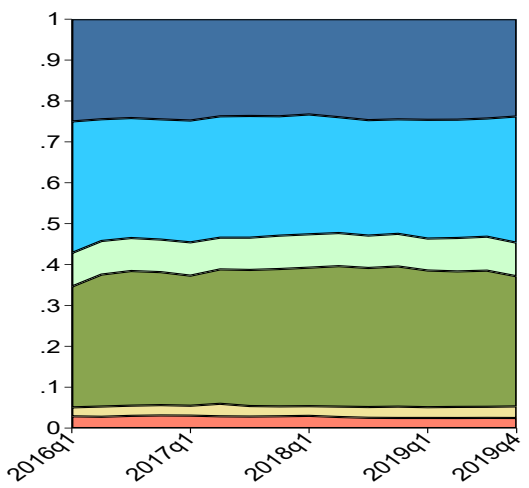

Large Public
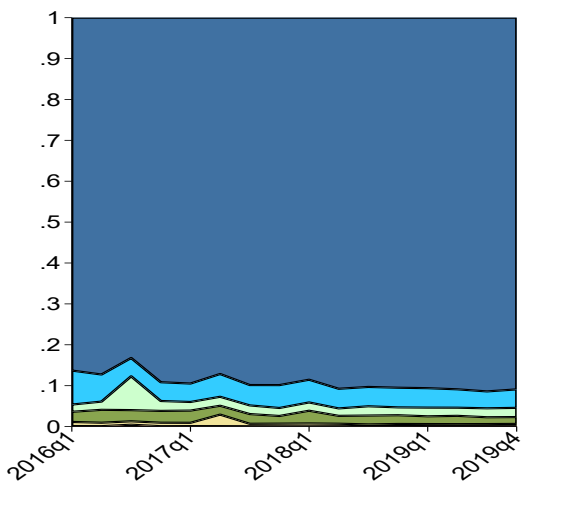

Note: The figure plots the value share of loans secured by different collateral types over time. The different types of collateral are cash and marketable securities (yellow); accounts receivable, inventory (green); blanket liens (light blue); fixed assets (mint); real estate (salmon); and unsecured loans (dark blue). The top three panels from left to right show loan values secured by the different collateral types and unsecured for private borrowers in the bottom quartile of assets (small), between the bottom and top quartile of assets (medium), and above the top quartile of assets (large). As an example, we add up the value of all loans for firms below the bottom quartile (Total Loan Value $t$ ). We then add up the value of all loans for firms within each quartile and loan category (Total Loan Value $c t$ ). The graph shows at each point in time the share of loan value accounted for each category Share $_{c t}=$ Total Loan Value $c t$ /Total Loan Value $t$. The bottom three panels present the same information for public borrowers. Source: FR Y14-Q H.1. 


\subsection{Extensive Margin Regressions: Collateralization}

To investigate the role of loan-specific collateral, we start by running an extensive margin regression:

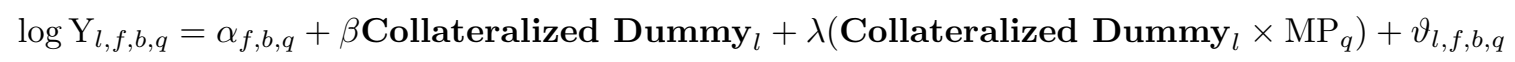

where loan-level quantities and interest rates are the dependent variables without aggregating to the firm-bank pair level. The decision to collaterize or not (given by a dummy of 1 in the collateralized dummy variable) in a given period is not exogenous and will depend on both firm and bank factors as the decision to lever-up. Hence, we use the same strategy in our leverage regressions and define a time-invariant collateralization dummy as of first quarter of the sample. The loan contract specifies the collateral in the first quarter and then MP surprises take place during the sample period. We identify from loans during the sample period drawn based on the initial collateral. Since there are new loan originations with new collateral during our sample period, we also use average collateral. Furthermore in addition to firm $\times$ quarter and bank $\times$ quarter fixed effects, we can also use firm $\times$ bank $\times$ quarter fixed effects, $\alpha_{f, b, q}$, in these loan-level regressions. These effects strengthen the identification as it controls all time varying firm and bank factors that collateralization decision is endogenous too. Though this strategy requires multiple loans over time for a given firm-bank pair. Over 50 percent of our firms have multiple loans from their banks.

We begin by running regression equation (3) using a collateral dummy variable equal to one if the loan is collateralized and zero otherwise, regardless of the type of collateral pledged. The results highlight a stark difference in the way that pledging collateral interacts with access to and the pricing of credit across firm types. Tables 9 and 10 show that for private borrowers, collateralizing a loan is associated with improved access to credit and lower prices. The opposite is true for public borrowers: collateralization is associated with lower loan amounts and higher prices. The first row in each table captures the effect of collateralizing a loan during normal times, using different sets of fixed effects. The results show that the positive (negative) association between collateral and loan quantity (price) holds regardless of which fixed effects are included. Hence, the results are robust to variation coming from demand and/or supply side or within a pair.

To assess the impact of monetary policy, we interact the collateral dummy variable with the policy surprises. The results are shown in the second row of Table 9 and 10. The negative coefficient of the interaction term in the first three columns of Table 9 implies that expansionary monetary policy strengthens the 'access to finance' effect of collateralizing loans for private firms. The negative coefficient on the interaction term for the last three columns indicates that effect of collateral in reducing prices is lower during monetary expansions. In 
other words, firms can pledge less collateral to lower spreads during expansions. The result should not be surprising because monetary policy narrowed spreads significantly during this period.

Table 10 shows that, for public firms, expansionary policy mitigates but does not reverse the negative relationship between collateral and credit. Moreover, expansionary monetary policy amplifies the positive relation between collateral and spreads. Public firms who pledge collateral borrow less and pay higher spreads in response to expansionary monetary policy surprises. The impact on credit spreads is stronger in the firm credit demand regression (column (4)). The interpretation is that distressed public firms pay higher spreads if their credit demand increases. Given that most public firms borrow unsecured, the higher cost of secured credit most likely reflects the monitoring costs associated with secured debt.

Table 9: Monetary Policy and Loan Level Outcomes: Private Firms

\begin{tabular}{|c|c|c|c|c|c|c|}
\hline & \multicolumn{3}{|c|}{ Quantity } & \multicolumn{3}{|c|}{ Prices } \\
\hline & $\begin{array}{c}(1) \\
\log (\text { Loan })\end{array}$ & $\begin{array}{c}(2) \\
\log (\text { Loan })\end{array}$ & $\begin{array}{c}(3) \\
\log (\text { Loan })\end{array}$ & $\begin{array}{c}(4) \\
\log (1+i)\end{array}$ & $\begin{array}{c}(5) \\
\log (1+i)\end{array}$ & $\begin{array}{c}(6) \\
\log (1+i)\end{array}$ \\
\hline Collateralized & $\begin{array}{c}0.2888^{* * *} \\
(0.0353)\end{array}$ & $\begin{array}{c}0.3467^{* * *} \\
(0.0523)\end{array}$ & $\begin{array}{c}0.4181^{* * *} \\
(0.0606)\end{array}$ & $\begin{array}{c}-0.0023^{* * *} \\
(0.0005)\end{array}$ & $\begin{array}{c}-0.0045^{* * *} \\
(0.0009)\end{array}$ & $\begin{array}{c}-0.0058^{* * *} \\
(0.0012)\end{array}$ \\
\hline Collateralized $\times{\text { MP } \text { Surprise }_{q}}$ & $\begin{array}{c}-0.9698^{* * *} \\
(0.1719)\end{array}$ & $\begin{array}{c}-2.1818^{* * * *} \\
(0.3730)\end{array}$ & $\begin{array}{c}-2.3107^{* * *} \\
(0.4394)\end{array}$ & $\begin{array}{c}-0.0130^{* * * *} \\
(0.0033)\end{array}$ & $\begin{array}{l}-0.0190^{*} \\
(0.0073)\end{array}$ & $\begin{array}{l}-0.0264^{*} \\
(0.0105)\end{array}$ \\
\hline Observations & 2984365 & 1563912 & 1371794 & 3128248 & 1564644 & 1377795 \\
\hline Adjusted $R^{2}$ & 0.724 & 0.454 & 0.282 & 0.634 & 0.428 & 0.357 \\
\hline Bank × Firm F.E. & Yes & Yes & No & Yes & Yes & No \\
\hline Bank $\times$ Quarter F.E. & Yes & No & No & Yes & No & No \\
\hline Firm $\times$ Quarter F.E. & No & Yes & No & No & Yes & No \\
\hline Bank $\times$ Firm $\times$ Quarter F.E. & No & No & Yes & No & No & Yes \\
\hline
\end{tabular}

Note: $+p<0.1,{ }^{*} p<0.05,{ }^{* *} p<0.01,{ }^{* * *} p<0.001$. This table presents the results of OLS regressions for the effect of collateral using loan level data at a quarterly frequency, for private firm sample. The dependent variable in columns (1) through (3) is the natural logarithm of the total committed loan amount; the dependent variable in columns (4) through (6) is the natural logarithm of the nominal real interest rates. Collateralized $_{q}$ is a dummy variable equal to one if the loan is collateralized, and zero otherwise. Double-clustered standard errors by firm and time are reported in parentheses.

\subsection{Intensive Margin Regressions: Collateral Types}

The next set of results replace the single collateral dummy with dummies for different collateral categories. Hence we run:

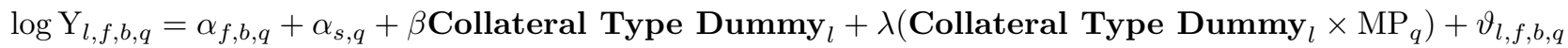


Table 10: Monetary Policy and Loan Level Outcomes: Public Firms

\begin{tabular}{|c|c|c|c|c|c|c|}
\hline & \multicolumn{3}{|c|}{ Quantity } & \multicolumn{3}{|c|}{ Prices } \\
\hline & $\begin{array}{c}(1) \\
\log (\text { Loan })\end{array}$ & $\begin{array}{c}(2) \\
\log (\operatorname{Loan})\end{array}$ & $\begin{array}{c}(3) \\
\log (\text { Loan })\end{array}$ & $\begin{array}{c}(4) \\
\log (1+i)\end{array}$ & $\begin{array}{c}(5) \\
\log (1+i)\end{array}$ & $\begin{array}{c}(6) \\
\log (1+i)\end{array}$ \\
\hline Collateralized & $\begin{array}{c}-0.6190^{* * *} \\
(0.0481)\end{array}$ & $\begin{array}{c}-0.6384^{* * *} \\
(0.0490)\end{array}$ & $\begin{array}{c}-0.8910^{* * *} \\
(0.0770)\end{array}$ & $\begin{array}{c}0.0074^{* * *} \\
(0.0006)\end{array}$ & $\begin{array}{c}0.0081^{* * *} \\
(0.0006)\end{array}$ & $\begin{array}{c}0.0108^{* * *} \\
(0.0009)\end{array}$ \\
\hline Collateralized $\times$ MP Surprise $_{q}$ & $\begin{array}{l}-0.6125^{*} \\
(0.2575)\end{array}$ & $\begin{array}{l}-0.4756 \\
(0.3938)\end{array}$ & $\begin{array}{l}-2.0066^{*} \\
(0.7709)\end{array}$ & $\begin{array}{c}-0.0233^{* * *} \\
(0.0050)\end{array}$ & $\begin{array}{c}-0.0157^{*} \\
(0.0069)\end{array}$ & $\begin{array}{l}-0.0092 \\
(0.0100)\end{array}$ \\
\hline Observations & 644446 & 634710 & 485440 & 639445 & 629677 & 481327 \\
\hline Adjusted $R^{2}$ & 0.506 & 0.490 & 0.284 & 0.479 & 0.513 & 0.378 \\
\hline Bank × Firm F.E. & Yes & Yes & No & Yes & Yes & No \\
\hline Bank $\times$ Quarter F.E. & Yes & No & No & Yes & No & No \\
\hline Firm $\times$ Quarter F.E. & No & Yes & No & No & Yes & No \\
\hline Bank $\times$ Firm $\times$ Quarter F.E. & No & No & Yes & No & No & Yes \\
\hline
\end{tabular}

Note: ${ }^{+} p<0.1,{ }^{*} p<0.05,{ }^{* *} p<0.01,{ }^{* * *} p<0.001$. This table presents the results of OLS regressions of the effect of collateral using loan level data at a quarterly frequency, for the public firm sample. The dependent variable in columns (1) through (3) is the natural logarithm of the total committed loan amount ; the dependent variable in columns (4) through (6) is the natural logarithm of the nominal real interest rates. Collateralized $_{q}$ is a dummy variable equal to one if the loan is collateralized, and zero otherwise. Double-clustered standard errors by firm and time are reported in parentheses.

Each dummy is equal to one when a loan is collateralized with that type of collateral and zero otherwise. To reduce the number of the categories, we combine fixed assets with real estate collateral because they represent physical assets. The 'unsecured' category remains omitted.

The results are reported in Table 11 for private firms and in Table 12 for public firms. For private firms, the result that collateralizing improves access to credit at a lower price is associated with three types of collateral, regardless of fixed effects: cash, AR\&I, and blanket liens. We argue that the values of these three types of collateral are inextricably linked to firm earnings and operations. During monetary expansions, the access to finance effect comes from AR\&I and blanket lien collateral, though fixed assets and real estate collateral also improve access to finance in the supply regression and when using within-loan variation. In terms of spreads, pledging AR\&I collateral reduces loan spreads during monetary expansions, showing the importance of operations-based collateral.

For public firms, Table 12 shows that all collateral types signal distress-less credit and higher spreads - regardless of which fixed effects are included. During monetary policy expansions, pledging cash, AR\&I, and blanket liens mitigates the negative impact on loan quantities-there is no effect coming from fixed assets and real estate. That said, the total effect shows that public firms borrow less when pledging all types of collateral during expansions (relative to unsecured). Finally, the effect on spreads is amplified when pledging blanket lien and AR\&I collateral. In other words, public firms pay higher spreads during monetary expansions when they pledge these types of collateral. Pledging cash, fixed assets, and real 
estate during monetary expansions partially mitigates the negative distress effect.

Table 11: The Role of Collateral: Private Firms

\begin{tabular}{|c|c|c|c|c|c|c|}
\hline & \multicolumn{3}{|c|}{ Quantity } & \multicolumn{3}{|c|}{ Prices } \\
\hline & $\begin{array}{c}(1) \\
\log (\operatorname{Loan})\end{array}$ & $\begin{array}{c}(2) \\
\log (\text { Loan })\end{array}$ & $\begin{array}{c}(3) \\
\log (\text { Loan })\end{array}$ & $\begin{array}{c}(4) \\
\log (1+i)\end{array}$ & $\begin{array}{c}(5) \\
\log (1+i)\end{array}$ & $\begin{array}{c}(6) \\
\log (1+i)\end{array}$ \\
\hline Fixed assets and real estate & $\begin{array}{c}0.0362 \\
(0.0324)\end{array}$ & $\begin{array}{l}-0.0298 \\
(0.0433)\end{array}$ & $\begin{array}{c}0.0332 \\
(0.0494)\end{array}$ & $\begin{array}{c}0.0015^{* *} \\
(0.0005)\end{array}$ & $\begin{array}{c}0.0009 \\
(0.0009)\end{array}$ & $\begin{array}{l}-0.0000 \\
(0.0012)\end{array}$ \\
\hline Cash and marketable sec. & $\begin{array}{c}0.2225^{* * *} \\
(0.0361)\end{array}$ & $\begin{array}{c}0.3331^{* * *} \\
(0.0536)\end{array}$ & $\begin{array}{c}0.3270^{* * * *} \\
(0.0713)\end{array}$ & $\begin{array}{c}-0.0049^{* * *} \\
(0.0006)\end{array}$ & $\begin{array}{c}-0.0070^{* * *} \\
(0.0010)\end{array}$ & $\begin{array}{c}-0.0093^{* * *} \\
(0.0013)\end{array}$ \\
\hline Act. receiv. and inventory & $\begin{array}{c}0.5424^{* * *} \\
(0.0406)\end{array}$ & $\begin{array}{c}0.7790^{* * *} \\
(0.0509)\end{array}$ & $\begin{array}{c}0.8924^{* * *} \\
(0.0535)\end{array}$ & $\begin{array}{c}-0.0046^{* * *} \\
(0.0006)\end{array}$ & $\begin{array}{c}-0.0082^{* * *} \\
(0.0010)\end{array}$ & $\begin{array}{c}-0.0102^{* * *} \\
(0.0013)\end{array}$ \\
\hline Blanket lien and other & $\begin{array}{c}0.3668^{* * *} \\
(0.0332)\end{array}$ & $\begin{array}{c}0.4817^{* * *} \\
(0.0431)\end{array}$ & $\begin{array}{c}0.5787^{* * *} \\
(0.0514)\end{array}$ & $\begin{array}{c}-0.0024^{* * *} \\
(0.0005)\end{array}$ & $\begin{array}{c}-0.0046^{* * *} \\
(0.0008)\end{array}$ & $\begin{array}{c}-0.0053^{* * *} \\
(0.0010)\end{array}$ \\
\hline Fixed assets and real estate $\times$ MP Surprise $_{q}$ & $\begin{array}{c}-0.0606 \\
(0.0811)\end{array}$ & $\begin{array}{c}-1.0468^{* * *} \\
(0.2082)\end{array}$ & $\begin{array}{c}-1.1313^{* *} \\
(0.2485)\end{array}$ & $\begin{array}{l}-0.0008 \\
(0.0017)\end{array}$ & $\begin{array}{c}-0.0107^{*} \\
(0.0051)\end{array}$ & $\begin{array}{c}-0.0178^{*} \\
(0.0072)\end{array}$ \\
\hline Cash and marketable sec. $\times$ MP Surprise $_{q}$ & $\begin{array}{l}-0.1948 \\
(0.1258)\end{array}$ & $\begin{array}{c}-0.9140^{* *} \\
(0.2931)\end{array}$ & $\begin{array}{c}-0.7354^{+} \\
(0.4310)\end{array}$ & $\begin{array}{c}0.0009 \\
(0.0026)\end{array}$ & $\begin{array}{l}-0.0040 \\
(0.0062)\end{array}$ & $\begin{array}{l}-0.0054 \\
(0.0093)\end{array}$ \\
\hline Act. receiv. and inventory $\times$ MP Surprise S $_{q}$ & $\begin{array}{c}-1.0223^{* * *} \\
(0.1391)\end{array}$ & $\begin{array}{c}-2.1088^{* * *} \\
(0.3011)\end{array}$ & $\begin{array}{c}-2.3031^{* * *} \\
(0.3342)\end{array}$ & $\begin{array}{c}-0.0118^{* * *} \\
(0.0026)\end{array}$ & $\begin{array}{l}-0.0135^{*} \\
(0.0052)\end{array}$ & $\begin{array}{c}-0.0227^{* *} \\
(0.0077)\end{array}$ \\
\hline Blanket lien and other $\times$ MP Surprise S $_{q}$ & $\begin{array}{c}-0.5070^{* * *} \\
(0.1064)\end{array}$ & $\begin{array}{c}-0.9747^{* * *} \\
(0.2348)\end{array}$ & $\begin{array}{l}-0.6990^{*} \\
(0.3015)\end{array}$ & $\begin{array}{l}-0.0018 \\
(0.0018)\end{array}$ & $\begin{array}{l}-0.0105^{*} \\
(0.0045)\end{array}$ & $\begin{array}{r}-0.0120^{+} \\
(0.0065)\end{array}$ \\
\hline Observations & 2650313 & 1362500 & 1192230 & 2781417 & 1365280 & 1199252 \\
\hline Adjusted $R^{2}$ & 0.734 & 0.472 & 0.307 & 0.647 & 0.442 & 0.376 \\
\hline Bank $\times$ Firm F.E. & Yes & Yes & No & Yes & Yes & No \\
\hline Bank $\times$ Quarter F.E. & Yes & No & No & Yes & No & No \\
\hline Firm $\times$ Quarter F.E. & No & Yes & No & No & Yes & No \\
\hline Bank $\times$ Firm $\times$ Quarter F.E. & No & No & Yes & No & No & Yes \\
\hline
\end{tabular}

Note: ${ }^{+} p<0.1,{ }^{*} p<0.05,{ }^{* *} p<0.01,{ }^{* * *} p<0.001$. This table presents the results of OLS regressions of the effect of collateral type using loan level data at a quarterly frequency, for the private firm sample. The dependent variable in columns (1) through (3) is the natural logarithm of the total committed loan amount; the dependent variable in columns (4) through (6) is the natural logarithm of the nominal real interest rates. The dependent variables are dummy variables equal to one if the loan is collateralized by specific type of collateral, zero otherwise; we drop the category "Unsecured". The coefficients for the collateral types are calculated but not displayed. Double-clustered standard errors by firm and time are reported in parentheses.

The collateral-type results suggest a "collateral pecking order". For both sets of firms, AR\&I and blanket liens seem to be the most valuable collateral-types, and they work exactly the same way. Importantly, for private firms, these two types of collateral drive all the access to finance results. Why is this the case?

The values of AR\&I and blanket lien collateral are both tied to firm earnings and operations in an important way that other fixed assets, such as real estate and machines, are not. The firm does not purchase this collateral like machines or land, it creates it. In particular, the values of AR\&I and blanket lien collateral are not derived from resale value or what lenders can recover in a spot market transaction, which is where the value of fixed assets and real estate lie. ${ }^{17}$ Consider one-period debt as in (Kiyotaki and Moore, 1997) where the relationship

\footnotetext{
${ }^{17}$ According to the standard industry dichotomy, loans secured by AR\&I are technically asset-based loans because the advance rate on the loan is based on a fraction of the book value of receivables rather than the future value of receipts. The advance rate for accounts receivable is generally much higher (up to 85 percent
} 
Table 12: The Role of Collateral: Public Firms

\begin{tabular}{|c|c|c|c|c|c|c|}
\hline & \multicolumn{3}{|c|}{ Quantity } & \multicolumn{3}{|c|}{ Prices } \\
\hline & $\begin{array}{c}(1) \\
\log (\operatorname{Loan})\end{array}$ & $\begin{array}{c}(2) \\
\log (\operatorname{Loan})\end{array}$ & $\begin{array}{c}(3) \\
\log (\operatorname{Loan})\end{array}$ & $\begin{array}{c}(4) \\
\log (1+i)\end{array}$ & $\begin{array}{c}(5) \\
\log (1+i)\end{array}$ & $\begin{array}{c}(6) \\
\log (1+i)\end{array}$ \\
\hline Fixed assets and real estate & $\begin{array}{c}-1.4410^{* * *} \\
(0.0609)\end{array}$ & $\begin{array}{c}-1.4400^{* * *} \\
(0.0703)\end{array}$ & $\begin{array}{c}-1.8022^{* * *} \\
(0.0757)\end{array}$ & $\begin{array}{c}0.0178^{* * *} \\
(0.0009)\end{array}$ & $\begin{array}{c}0.0174^{* * *} \\
(0.0009)\end{array}$ & $\begin{array}{c}0.0219^{* * *} \\
(0.0011)\end{array}$ \\
\hline Cash and marketable sec. & $\begin{array}{c}-0.5642^{* * *} \\
(0.0633)\end{array}$ & $\begin{array}{c}-0.5283^{* * *} \\
(0.0697)\end{array}$ & $\begin{array}{c}-0.7002^{* * *} \\
(0.1222)\end{array}$ & $\begin{array}{l}0.0034^{* *} \\
(0.0011)\end{array}$ & $\begin{array}{c}0.0048^{* * *} \\
(0.0011)\end{array}$ & $\begin{array}{c}0.0060^{* *} \\
(0.0020)\end{array}$ \\
\hline Act. receiv. and inventory & $\begin{array}{c}-0.1679^{*} \\
(0.0690)\end{array}$ & $\begin{array}{c}-0.2192^{* *} \\
(0.0756)\end{array}$ & $\begin{array}{l}-0.2921^{*} \\
(0.1187)\end{array}$ & $\begin{array}{c}0.0032^{* * *} \\
(0.0007)\end{array}$ & $\begin{array}{c}0.0036^{* * *} \\
(0.0008)\end{array}$ & $\begin{array}{c}0.0028^{*} \\
(0.0013)\end{array}$ \\
\hline Blanket lien and other & $\begin{array}{c}-0.3759^{* * *} \\
(0.0483)\end{array}$ & $\begin{array}{c}-0.3934^{* * *} \\
(0.0505)\end{array}$ & $\begin{array}{c}-0.5355^{* * *} \\
(0.0913)\end{array}$ & $\begin{array}{c}0.0045^{* * *} \\
(0.0005)\end{array}$ & $\begin{array}{c}0.0052^{* * *} \\
(0.0005)\end{array}$ & $\begin{array}{c}0.0073^{* * *} \\
(0.0009)\end{array}$ \\
\hline Fixed assets and real estate $\times$ MP Surprise $_{q}$ & $\begin{array}{l}1.0635^{*} \\
(0.4006)\end{array}$ & $\begin{array}{l}0.9617^{+} \\
(0.5166)\end{array}$ & $\begin{array}{l}-0.3164 \\
(0.8001)\end{array}$ & $\begin{array}{c}0.0139 \\
(0.0097)\end{array}$ & $\begin{array}{c}0.0060 \\
(0.0105)\end{array}$ & $\begin{array}{c}0.0275^{*} \\
(0.0127)\end{array}$ \\
\hline Cash and marketable sec. $\times$ MP Surprise $_{q}$ & $\begin{array}{c}-1.7177^{* *} \\
(0.5340)\end{array}$ & $\begin{array}{c}-1.6142^{*} \\
(0.6360)\end{array}$ & $\begin{array}{c}-2.5546^{+} \\
(1.4276)\end{array}$ & $\begin{array}{c}0.0041 \\
(0.0102)\end{array}$ & $\begin{array}{l}0.0216^{+} \\
(0.0116)\end{array}$ & $\begin{array}{c}0.0760^{* *} \\
(0.0246)\end{array}$ \\
\hline Act. receiv. and inventory $\times$ MP Surprise $_{q}$ & $\begin{array}{c}-1.7494^{* * *} \\
(0.3921)\end{array}$ & $\begin{array}{c}-2.8136^{* * *} \\
(0.5887)\end{array}$ & $\begin{array}{c}-5.5757^{* * *} \\
(1.1364)\end{array}$ & $\begin{array}{c}-0.0399^{* * *} \\
(0.0055)\end{array}$ & $\begin{array}{c}-0.0287^{* * *} \\
(0.0072)\end{array}$ & $\begin{array}{c}-0.0465^{* *} \\
(0.0134)\end{array}$ \\
\hline Blanket lien and other $\times$ MP Surprise S $_{q}$ & $\begin{array}{l}-0.7591^{*} \\
(0.3102)\end{array}$ & $\begin{array}{l}-1.1205^{*} \\
(0.4592)\end{array}$ & $\begin{array}{l}-2.2961^{*} \\
(0.9398)\end{array}$ & $\begin{array}{c}-0.0333^{* * *} \\
(0.0047)\end{array}$ & $\begin{array}{c}-0.0226^{* *} \\
(0.0065)\end{array}$ & $\begin{array}{r}-0.0203^{+} \\
(0.0116)\end{array}$ \\
\hline Observations & 644446 & 634710 & 485440 & 639445 & 629677 & 481327 \\
\hline Adjusted $R^{2}$ & 0.538 & 0.523 & 0.339 & 0.491 & 0.525 & 0.398 \\
\hline Bank $\times$ Firm F.E. & Yes & Yes & No & Yes & Yes & No \\
\hline Bank $\times$ Quarter F.E. & Yes & No & No & Yes & No & No \\
\hline Firm $\times$ Quarter F.E. & No & Yes & No & No & Yes & No \\
\hline Bank $\times$ Firm $\times$ Quarter F.E. & No & No & Yes & No & No & Yes \\
\hline
\end{tabular}

Note: ${ }^{+} p<0.1,{ }^{*} p<0.05,{ }^{* *} p<0.01,{ }^{* * *} p<0.001$. This table presents the results of OLS regressions of the effect of collateral type using loan level data at a quarterly frequency, for the public firm sample. The dependent variable in columns (1) through (3) is the natural logarithm of the total committed loan amount ; the dependent variable in columns (4) through (6) is the natural logarithm of the nominal real interest rates. The dependent variables are dummy variables equal to one if the loan is collateralized by specific type of collateral, zero otherwise; we drop the category "Unsecured". The coefficients for the collateral types are calculated but not displayed. Double-clustered standard errors by firm and time are reported in parentheses.

between collateral value and borrowing is determined by the standard borrowing constraint $R b_{t} \leq q_{t+1} k_{t+1}$, where $R b_{t}$ is the gross repayment amount on borrowing at time $t$ and $k_{t+1}$ and $q_{t+1}$ are the holdings and price of capital in following period. The subtle but important distinction between tangible assets, such as real estate and machines, and AR\&I embedded in the capital stock, $k_{t+1}$, is that the book value of AR\&I collateral only exists because of the firm's ability to create sales that generate the receivables and inventory. In other words, the operations of the firm combine intellectual property, managerial talent, marketing, etc. to generate sales and the receipts in the current period that serve as collateral.

The inability to separate the liquidation value of AR\&I from the going-concern value embedded in blanket liens is particularly important for small private borrowers who do not have large amounts of other tangible fixed assets to pledge. In these cases, blanket liens

of book value) than the advance rate for inventory (only up to 65 percent), which largely reflects differences in the liquidity of the assets. However, most AR\&I loans are tied to the "AR" rather than the "I" (See the documentation in the OCC Comptroller's Handbook on Asset-Based Lending). 
are thus close substitutes for AR\&I that also give the lender additional security. ${ }^{18}$ Using the trees/machines and fruit/engineers metaphor of Kiyotaki and Moore (1997), fixed assets and real estate are the trees or the machines that firms purchase from one another in the spot market and borrow against for production. Within the firm, managerial know-how and engineers' ability to use tools combines with the machines to generate output or fruit. Hence, AR\&I and blanket lien collateral are different from trees/machines, and are frequently used as collateral. Thus, the tree's fruit is not bruised and unusable; it becomes compost providing additional nutrients to generate additional future fruit. In sum, it is not the recovery or liquidation value of AR\&I that is important as with traditional "asset-based" lending; it is the fact that its value comes from current earnings and cannot exist outside of firm production. ${ }^{19}$

\subsection{Earnings and Operations-Based vs. Asset-Based Collateral}

Based on our results shown in above tables, we group AR\&I with blanket liens in Figure 9 as 'Earnings and Operations-Based Collateral' in light blue. The figure makes clear that, for SMEs and private firms, earnings and operations-based collateral dominates all others. The category depicted in orange is real estate and fixed assets. The unsecured category stays in dark blue and cash and marketable securities is in yellow. With this grouping, we create a new dummy variable for 'Earnings and Operations-Based Collateral' and horse-race it against 'Asset-Based Collateral' composed of fixed assets and real estate. We rerun our regressions with these two categories, leaving 'unsecured' as the omitted category.

The results are shown in Tables 13 and 14 for private and public firms, respectively. The second row of Table 13 shows clearly that, among private firms, 'Earnings and OperationsBased Collateral' drive the access to credit and pricing results. These results hold regardless of what fixed effects are included. The fourth row of the table shows that the expansionary monetary policy effects are driven by this collateral on the pricing side. 'Asset-Based Collateral' also has an access to finance role for private firms during monetary expansions, as shown in columns (2) and (3), when bank credit supply variation is used. This is expected since these firms are financially constrained and any collateral will act as a tool for access

\footnotetext{
${ }^{18}$ This intuition that blanket liens and AR\&I collateral are substitutes is confirmed in an interview with the CFO of a medium-sized private company, with annual sales of nearly $\$ 70 \mathrm{mn}$. They note that in their multiple loan facilities with a large bank, their working capital loans (a standard term for AR\&I loans) are secured by a blanket lien on the firm assets, and not just the AR\&I.

${ }^{19}$ Based on our interviews with SME CEOs, we observe the following: Accounts receivable (AR) account for 20 percent of annual sales among firms with $\$ 50-100$ million in annual sales. When obtaining working capital loans with "AR\&I" collateral, they submit weekly AR and inventory reports to the bank. This means that if they obtain a $\$ 1$ million revolver now and their AR continues to increase, then they will be eligible for a new revolver with a higher limit. Eligible AR collateral for loans is generally given 60 days in advance, which means that eligible AR collateral that is booked now must be paid within 60 days.
} 
Figure 9: Collateral Grouping Across Firm Size Distribution

Small Private

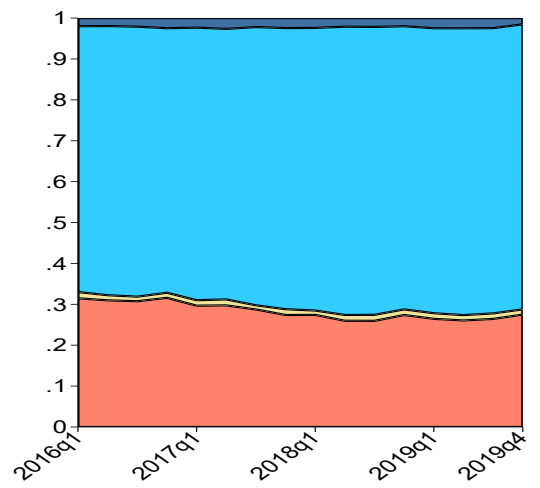

Small Public

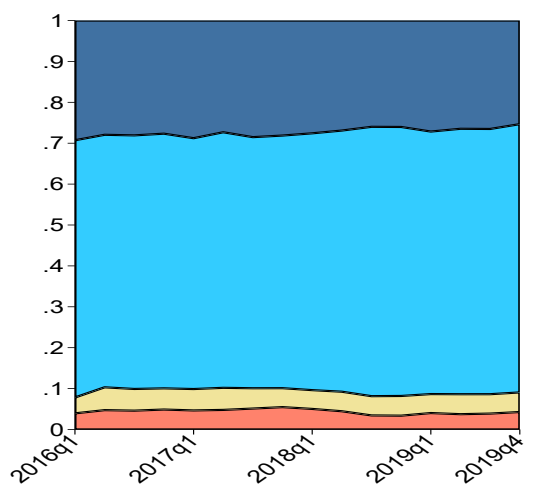

Medium Private

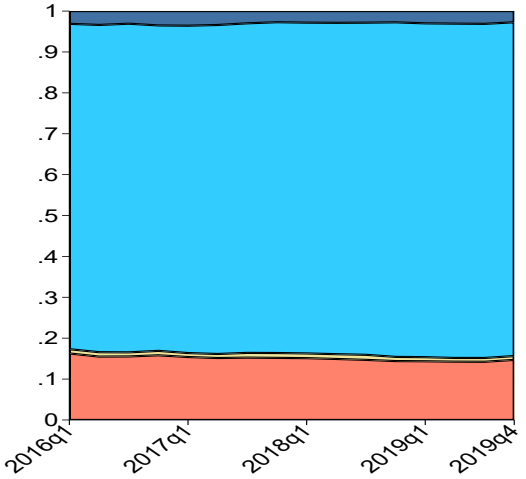

Medium Public

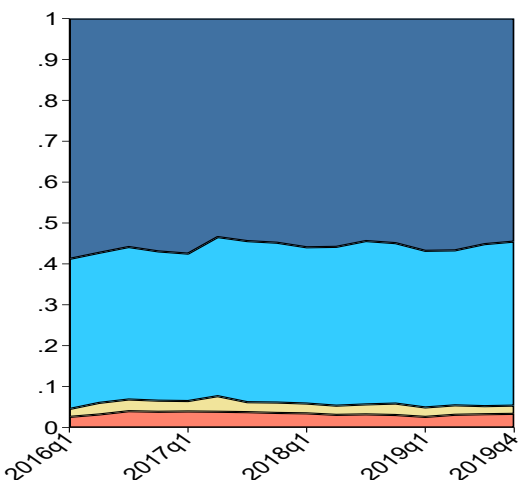

Unsecured

Accounts Receivable,

Inventory,

Blanket Liens, and Other

Cash and Marketable

Securities

Real Estate and

Fixed Assets
Large Private

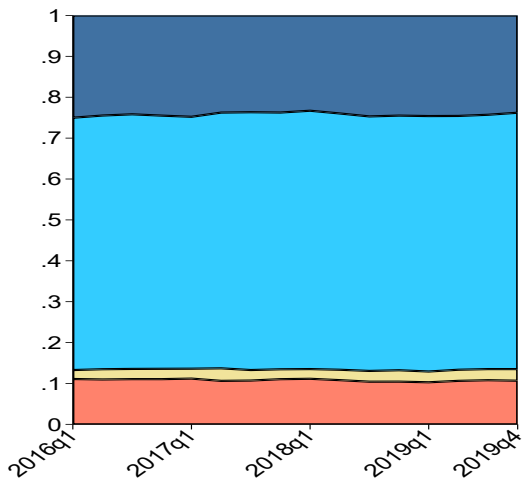

Large Public

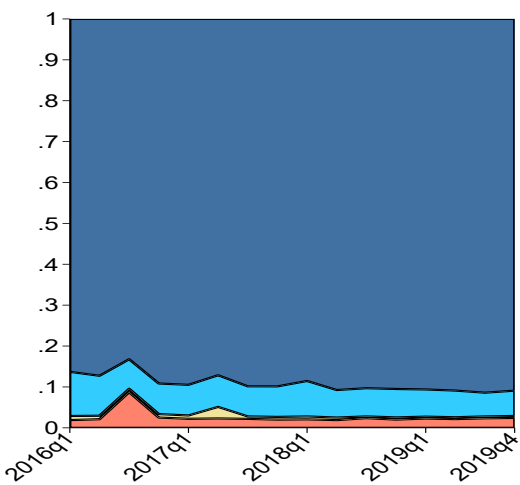

Note: The figure plots the proportion of loans by value secured by different collateral types over time. The different types of collateral are real estate and fixed assets (in red); cash and marketable securities (in yellow); accounts receivable, inventory, and blanket liens (in light blue); and unsecured loans (in dark blue). The top three panels from left to right show the proportion of loans secured by the different collateral types and unsecured for private borrowers in the bottom quartile of assets (small), between the bottom and top quartile of assets (medium), and above the top quartile of assets (large). As an example, we add up the value of all loans for firms below the bottom quartile (Total Loan $t$ ). We then add up the value of all loans for

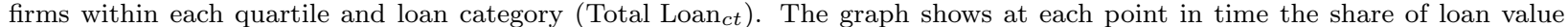
accounted for each category Share $c t=$ Total $\operatorname{Loan}_{c t} /$ Total Loan $t$. The bottom three panels present the same information for public borrowers. Source: FR Y14-Q H.1.

to finance. However, the impact of 'Earning and Operations-Based Collateral' is stronger because smaller firms do not have sufficient quantities of fixed assets to fully relax their borrowing constraints.

The first two rows of Table 14 show that, for public firms, both types of collateral signal distress. Expansionary monetary policy ameliorates the distress problem, shown in the last 
row of Table 14, but does not completely reverse it and only for loan quantities when pledging 'Earnings and Operations-Based Collateral'. In terms of spreads, both during normal times and monetary expansions, public firms who pledge collateral pay higher spreads than firms who borrow unsecured, signalling distress and the cost to monitor secured claims.

Table 13: The Role of Collateral: Private Firms

\begin{tabular}{|c|c|c|c|c|c|c|}
\hline & \multicolumn{3}{|c|}{ Quantity } & \multicolumn{3}{|c|}{ Prices } \\
\hline & $\begin{array}{c}(1) \\
\log (\text { Loan })\end{array}$ & $\begin{array}{c}(2) \\
\log (\text { Loan })\end{array}$ & $\begin{array}{c}(3) \\
\log (\text { Loan })\end{array}$ & $\begin{array}{c}(4) \\
\log (1+i)\end{array}$ & $\begin{array}{c}(5) \\
\log (1+i)\end{array}$ & $\begin{array}{c}(6) \\
\log (1+i)\end{array}$ \\
\hline Asset-based & $\begin{array}{l}0.0544^{+} \\
(0.0301)\end{array}$ & $\begin{array}{c}-0.0204 \\
(0.0458)\end{array}$ & $\begin{array}{c}0.0278 \\
(0.0546)\end{array}$ & $\begin{array}{l}0.0009^{+} \\
(0.0005)\end{array}$ & $\begin{array}{c}-0.0001 \\
(0.0009)\end{array}$ & $\begin{array}{c}-0.0010 \\
(0.0012)\end{array}$ \\
\hline Earnings \& Operations-based & $\begin{array}{c}0.4106^{* * *} \\
(0.0402)\end{array}$ & $\begin{array}{c}0.5765^{* * *} \\
(0.0545)\end{array}$ & $\begin{array}{c}0.6912^{* * *} \\
(0.0608)\end{array}$ & $\begin{array}{c}-0.0038^{* * *} \\
(0.0005)\end{array}$ & $\begin{array}{c}-0.0067^{* * *} \\
(0.0009)\end{array}$ & $\begin{array}{c}-0.0085^{* * *} \\
(0.0012)\end{array}$ \\
\hline Asset-based $\times \mathrm{MP}_{q}$ & $\begin{array}{c}-0.1172 \\
(0.1277)\end{array}$ & $\begin{array}{c}-1.5071^{* * *} \\
(0.3319)\end{array}$ & $\begin{array}{c}-1.5839^{* * *} \\
(0.4050)\end{array}$ & $\begin{array}{c}-0.0021 \\
(0.0031)\end{array}$ & $\begin{array}{c}-0.0165^{*} \\
(0.0077)\end{array}$ & $\begin{array}{c}-0.0260^{*} \\
(0.0107)\end{array}$ \\
\hline Earnings \& Operations-based $\times \mathrm{MP}_{q}$ & $\begin{array}{c}-1.4829^{* * *} \\
(0.2144)\end{array}$ & $\begin{array}{c}-2.5766^{* * *} \\
(0.4032)\end{array}$ & $\begin{array}{c}-2.5402^{* * *} \\
(0.4689)\end{array}$ & $\begin{array}{c}-0.0173^{* * *} \\
(0.0035)\end{array}$ & $\begin{array}{l}-0.0203^{*} \\
(0.0074)\end{array}$ & $\begin{array}{l}-0.0293^{*} \\
(0.0107)\end{array}$ \\
\hline Observations & 2984365 & 1563912 & 1371794 & 3128248 & 1564644 & 1377795 \\
\hline Adjusted $R^{2}$ & 0.731 & 0.474 & 0.310 & 0.635 & 0.435 & 0.366 \\
\hline Bank × Firm F.E. & Yes & Yes & No & Yes & Yes & No \\
\hline Bank $\times$ Quarter F.E. & Yes & No & No & Yes & No & No \\
\hline Firm $\times$ Quarter F.E. & No & Yes & No & No & Yes & No \\
\hline Bank $\times$ Firm $\times$ Quarter F.E. & No & No & Yes & No & No & Yes \\
\hline
\end{tabular}

Note: ${ }^{+} p<0.1,{ }^{*} p<0.05,{ }^{* *} p<0.01,{ }^{* * *} p<0.001$. This table presents the results of OLS regressions of the effect of collateral type using loan level data at a quarterly frequency, for the private firm sample. The dependent variable in columns (1) through (3) is the natural logarithm of the total committed loan amount ; the dependent variable in columns (4) through (6) is the natural logarithm of the nominal real interest rates. The dependent variables are dummy variables equal to one if the loan is collateralized by specific type of collateral, zero otherwise. "Asset-Based" is a dummy variable equal to one if the collateral pledge is either Real Estate, Fixed Assets or Cash and marketable securities; "Earning and Operations-Based" is equal to one if the collateral pledged is either blanket lien, account receivable and inventory or other; we drop the category "Unsecured". The coefficients for the collateral types are calculated but not displayed. Double-clustered standard errors by firm and time are reported in parentheses.

The fact that the relationship between pledging collateral and spreads is the opposite for private versus public firms strengthens our argument that collateral is a measure of access to finance for private firms and signals default risk for public firms. ${ }^{20}$ Collateral signals default risk for public borrowers because, otherwise, they are not financially constrained, while small, private firms are. The existing empirical literature finds mixed results on the relation between collateral and spreads, which is due to using different samples of firms and banks. For example, Berger and Udell (1990) use bank-level data and show that collateralized loans have higher interest rates in the U.S. Berger, Frame, and Ioannidou (2016) show the same result in Bolivia. di Giovanni, Kalemli-Özcan, Ulu, and Baskaya (2021) find the same

\footnotetext{
${ }^{20}$ Very small private firms who lack collateral cannot access credit as they are screened out of the market as in Darst, Refayet, and Vardoulakis (2020). Although we do not observe this extensive margin, as our data is on firms who borrow, our results show that the same intuition works at the intensive margin.
} 
Table 14: The Role of Collateral: Public Firms

\begin{tabular}{|c|c|c|c|c|c|c|}
\hline & \multicolumn{3}{|c|}{ Quantity } & \multicolumn{3}{|c|}{ Prices } \\
\hline & $\begin{array}{c}(1) \\
\log (\operatorname{Loan})\end{array}$ & $\begin{array}{c}(2) \\
\log (\operatorname{Loan})\end{array}$ & $\begin{array}{c}(3) \\
\log (\text { Loan })\end{array}$ & $\begin{array}{c}(4) \\
\log (1+i)\end{array}$ & $\begin{array}{c}(5) \\
\log (1+i)\end{array}$ & $\begin{array}{c}(6) \\
\log (1+i)\end{array}$ \\
\hline Asset-based & $\begin{array}{c}-1.2454^{* * *} \\
(0.0543)\end{array}$ & $\begin{array}{c}-1.2489^{* * *} \\
(0.0607)\end{array}$ & $\begin{array}{c}-1.6386^{* * *} \\
(0.0719)\end{array}$ & $\begin{array}{c}0.0146^{* * *} \\
(0.0008)\end{array}$ & $\begin{array}{c}0.0148^{* * *} \\
(0.0008)\end{array}$ & $\begin{array}{c}0.0195^{* * *} \\
(0.0010)\end{array}$ \\
\hline Earnings \& Operations-based & $\begin{array}{c}-0.3105^{* * *} \\
(0.0516)\end{array}$ & $\begin{array}{c}-0.3421^{* * *} \\
(0.0538)\end{array}$ & $\begin{array}{c}-0.4388^{* * *} \\
(0.0949)\end{array}$ & $\begin{array}{c}0.0041^{* * *} \\
(0.0005)\end{array}$ & $\begin{array}{c}0.0048^{* * *} \\
(0.0006)\end{array}$ & $\begin{array}{c}0.0054^{* * *} \\
(0.0009)\end{array}$ \\
\hline Asset-based $\times \mathrm{MP}_{q}$ & $\begin{array}{c}0.5611 \\
(0.3421)\end{array}$ & $\begin{array}{c}0.5472 \\
(0.4600)\end{array}$ & $\begin{array}{l}-0.3345 \\
(0.7612)\end{array}$ & $\begin{array}{c}0.0116 \\
(0.0086)\end{array}$ & $\begin{array}{c}0.0088 \\
(0.0094)\end{array}$ & $\begin{array}{c}0.0305^{*} \\
(0.0120)\end{array}$ \\
\hline Earnings \& Operations-based $\times \mathrm{MP}_{q}$ & $\begin{array}{c}-1.3400^{* * *} \\
(0.2895)\end{array}$ & $\begin{array}{c}-1.7572^{* * *} \\
(0.4475)\end{array}$ & $\begin{array}{c}-4.0888^{* * *} \\
(0.9127)\end{array}$ & $\begin{array}{c}-0.0364^{* * *} \\
(0.0046)\end{array}$ & $\begin{array}{c}-0.0260^{* * *} \\
(0.0064)\end{array}$ & $\begin{array}{c}-0.0300^{* *} \\
(0.0106)\end{array}$ \\
\hline Observations & 644446 & 634710 & 485440 & 639445 & 629677 & 481327 \\
\hline Adjusted $R^{2}$ & 0.530 & 0.516 & 0.330 & 0.486 & 0.521 & 0.390 \\
\hline Bank × Firm F.E. & Yes & Yes & No & Yes & Yes & No \\
\hline Bank $\times$ Quarter F.E. & Yes & No & No & Yes & No & No \\
\hline Firm $\times$ Quarter F.E. & No & Yes & No & No & Yes & No \\
\hline Bank $\times$ Firm $\times$ Quarter F.E. & No & No & Yes & No & No & Yes \\
\hline
\end{tabular}

Note: ${ }^{+} p<0.1,{ }^{*} p<0.05,{ }^{* *} p<0.01,{ }^{* * *} p<0.001$. This table presents the results of OLS regressions of the effect of collateral type using loan level data at a quarterly frequency, for the public firm sample. The dependent variable in columns (1) through (3) is the natural logarithm of the total committed loan amount ; the dependent variable in columns (4) through (6) is the natural logarithm of the nominal real interest rates. The dependent variables are dummy variables equal to one if the loan is collateralized by specific type of collateral, zero otherwise. "Asset-Based" is a dummy variable equal to one if the collateral pledge is either Real Estate, Fixed Assets or Cash and marketable securities; "Earning and Operations-Based" is equal to one if the collateral pledged is either blanket lien, account receivable and inventory or other; we drop the category "Unsecured". The coefficients for the collateral types are calculated but not displayed. Double-clustered standard errors by firm and time are reported in parentheses.

negative relation as us using data on the universe of firms from Turkey. Luck and Santos (2019), also using FR Y-14 data, show that small firms who post collateral pay lower rates. Using publicly listed firms, Rauh and Sufi (2010) shows that there is a positive relation between posting collateral and being a low quality firm in distress.

\subsection{Collateral and Leverage}

To recap our results: First, monetary expansions relax constraints for high leverage SMEs. Second, collateral constraints relax the most for 'Earnings and Operations-Based Collateral'.

To show the strong connection between these two sets of results, we go back to our baseline regressions at the firm-bank level and run a horse-race without restricting the credit demand or credit supply channels, for the sample of private firms. That is, we only use firm $\times$ bank $\left(\alpha_{f, b}\right)$ and sector $\times$ quarter $\left(\alpha_{s, q}\right)$ fixed effects to take out average differences and sector-level shocks and trends. We want both demand and supply side of credit to drive this horse-race since we want to pin down the fact that leverage, being backed by earnings and operations-based collateral, drives equilibrium credit outcomes. The direct effect of monetary policy is absorbed by the quarter fixed effects as before. In particular, we run a horse-race 
regression:

$$
\begin{aligned}
\log \sum_{l \in \mathcal{L}(f, b, q)} Y_{f, b, q}(l) & =\alpha_{f, b}+\alpha_{s, q}+\kappa\left(\text { High Leverage } \text { Firm }_{f} \times \frac{1}{N} \sum_{k=0}^{N} \mathrm{MP}_{q-k}\right) \\
& +\omega\left(\text { High Earnings-Operations Collateral Firm } f \times \frac{1}{N} \sum_{k=0}^{N} \mathrm{MP}_{q-k}\right)+\vartheta_{f, b, q}
\end{aligned}
$$

High Earnings and Operations Collateral is a dummy variable equal to one for firms above the median in the distribution of the share of loans collateralized with earnings and operations-based collateral, on average. The 'High Leverage' dummy is defined as before. The results in Table 15 column (1) clearly show that higher earnings and operations collateral firms borrow more relative to other firms during expansionary monetary policy. Column (2) shows the baseline result that high leverage firms borrow more during expansions. Finally, the horse race in column (3) shows that high leverage captures most of the earnings and operations collateral effect because leverage among these firms is tied to earnings and operations-based collateral.

Table 15: The Role of Collateral and Leverage

\begin{tabular}{lccc}
\hline Dep. Var: $\log (\operatorname{Loan})$ & $(1)$ & $(2)$ & $(3)$ \\
\hline High Earnings and Operations Collateral $\times \mathrm{MP}_{q}$ & $-0.1759^{* *}$ & & $-0.1559^{*}$ \\
& $(0.0591)$ & & $(0.0575)$ \\
High Leverage Firm $\times \mathrm{MP}_{q}$ & & $-0.5922^{* * *}$ & $-0.5870^{* * *}$ \\
& & $(0.0845)$ & $(0.0836)$ \\
\hline Observations & 2133266 & 2133266 & 2133266 \\
Adjusted $R^{2}$ & 0.938 & 0.938 & 0.938 \\
Bank $\times$ Firm F.E. & Yes & Yes & Yes \\
Sector $\times$ Quarter F.E. & Yes & Yes & Yes \\
\hline Note: ${ }^{+} p<0.1,^{*} p<0.05,{ }^{* *} p<0.01,{ }^{* * *} p<0.001$. This table presents the results of OLS \\
regressions for bank-firm level at a quarterly frequency. High Leverage Firm is a dummy equal to one \\
if the firm leverage is above the sample median and is based on short-term debt. Double-clustered \\
standard errors by firm and time are reported in parentheses.
\end{tabular}

Why do SMEs leverage is against earnings and operations-based collateral mainly composed of AR\&I and blanket lien? Technically, blanket liens are loans secured by all firm assets, which gives the lender a legal claim to all of a borrower's business assets in the event of default. A loan secured by a blanket lien will cover the entire firm and all unencumbered assets not already pledged as collateral. However, if a borrower previously pledged a specific asset-such as real estate or some other fixed asset-to secure a loan, then a future loan with a blanket lien is secured only by the firm's remaining unencumbered assets. Accounts receivable and inventory are usually what remain after other fixed assets have been pledged. 
Figure 10 shows that use of blanket liens by SMEs is due to a trade-off between lack of physical assets and a desire to borrow but being financially constrained. We plot the share of loans secured by blanket lien for each decile of the fixed assets distribution in panel (a), for each decile of total assets distribution in panel (b) and for each decile of fixed to total assets distribution in panel (c). If blanket lien collateral covers mostly fixed assets, then this relationship should be positive. The data shows that the relationship is negative; larger firms with more fixed assets use fewer blanket liens as collateral to secure funding. Table 16 shows, for the average private firm with existing collateralized loans, the share of subsequent loans secured by different collateral types. For example, the first row shows that, conditional on existing loans being collateralized by non-blanket lien, the share of new loans secured by blanket lien is 19.5 percent. More importantly, conditional on having already encumbered fixed assets and real estate, the share of additional loans secured by AR\&I and AR\&I and blanket liens 17.2 percent and 35 percent respectively. This evidence further indicates that blanket liens, like AR\&I, secure additional loans and do not simply proxy for liens against fixed assets and real estate.

Figure 10: Relation Between Blanket Liens and Fixed Assets for Private Firms

(a) Fixed Assets

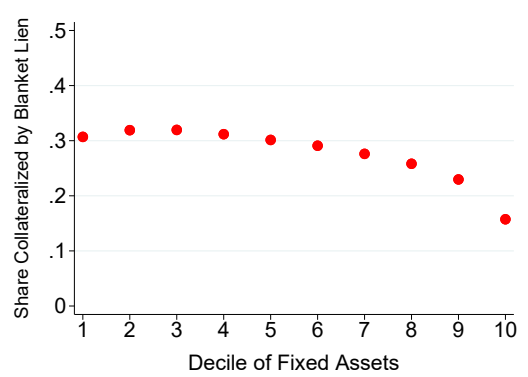

(b) Total Assets

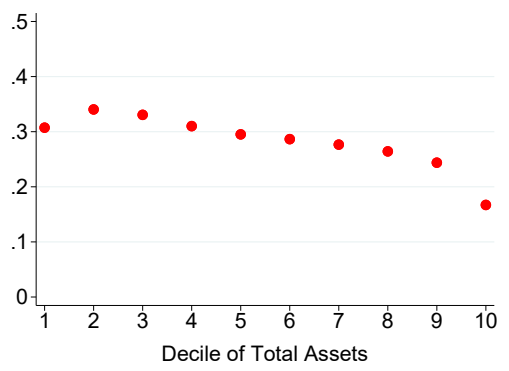

(c) Fixed Assets over Total Assets

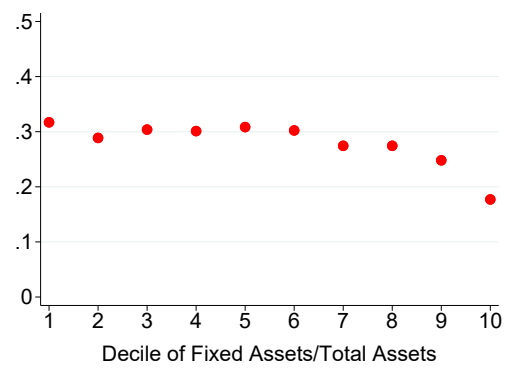

Note: Each panel shows the share of loans secured by blanket liens across: (a) each decile of the fixed assets distribution, (b) each decile of the total assets distribution and (c) each decile of the ratio of fixed assets over total assets. The plots only consider private firms. 
Table 16: Multiple Loans Secured by Different Types of Collateral for the Average Private Firm

\begin{tabular}{ll}
\hline \multicolumn{2}{l}{ Share of Additional Loans Collateralized by } \\
\hline Blanket Lien (1) & 0.1950 \\
AR\&I (2) & 0.1725 \\
AR\&I and Blanket Lien (3) & 0.3508 \\
\hline
\end{tabular}

Note: (1) Firms with more than one loan and at least one non-blanket lien loan. (2) Firms with more than one loan and at least one fixed assets and real estate loan. (3) Consider firms with more than one loan and at least one fixed assets and real estate loan.

\section{Can Results be Explained by the Lender-Side?}

So far we have focused mostly on the impact of monetary policy on credit demand. Can our results be driven by the bank side? Next we investigate the role of bank heterogeneity in lending by running the standard regression in the literature, that is:

$$
\begin{aligned}
\log \sum_{l \in \mathcal{L}(f, b, q)} Y_{f, b, q}(l) & =\alpha_{f, b}+\alpha_{f, q} \\
& +\omega\left(\text { High Leverage } \text { Bank }_{b} \times \frac{1}{N} \sum_{k=0}^{N} \mathrm{MP}_{q-k}\right)+\vartheta_{f, b, q}
\end{aligned}
$$

This is a much more restrictive specification than the one used for firm leverage because identifying $\omega$ requires variation from firms borrow from multiple banks. Identifying $\kappa$ in the demand regressions simply requires that banks lend to multiple firms in each quarter, which is always the case. Hence, firms are not dropped from the demand regression and there is no concern about the representativeness of the sample, but in the above regression this can be a concern, as firms borrowing from a single bank will be dropped.

Equation (6) helps determine if our results so far are misinterpreted. For example, instead of expansionary monetary policy causing high leverage firms to increase borrowing, the additional borrowing could be due to high leverage firms switching to high leverage banks during monetary expansions if those banks extend more credit. Our results based on the regression specification in (6) suggest this is not the case. In addition, specification (6) also allows us to test for risk-taking behavior among banks.

Table 17 shows the results. During monetary policy expansions, highly levered banks supply fewer loans at lower prices, though the price effects are weak. The results are mainly driven by private firms in columns (2) and (5). Hence, the supply results for private firms 
are the exact opposite of the firm credit-demand regressions. Moreover, the results are also inconsistent with the supply-side risk taking channel. Risk taking by banks should manifest as more lending to smaller and less transparent private borrowers, not less. This means that low leverage banks lend more to private borrowers, consistent with other papers using U.S. data.

Table 17: Monetary Policy and Credit Outcomes: Supply-Side

\begin{tabular}{|c|c|c|c|c|c|c|}
\hline & \multicolumn{3}{|c|}{ Quantity: $\log (\operatorname{Loan})$} & \multicolumn{3}{|c|}{ Price: $\log (1+i)$} \\
\hline & (1) & $(2)$ & $(3)$ & $(4)$ & $(5)$ & $(6)$ \\
\hline & All & Private & Public & All & Private & Public \\
\hline High Leverage Bank $\times$ MP Surprise $_{q}$ & $\begin{array}{c}0.4026^{* * *} \\
(0.1130)\end{array}$ & $\begin{array}{c}0.5429^{* * *} \\
(0.1319)\end{array}$ & $\begin{array}{c}0.1605 \\
(0.1559)\end{array}$ & $\begin{array}{l}0.0069^{* *} \\
(0.0021)\end{array}$ & $\begin{array}{c}0.0066^{*} \\
(0.0027)\end{array}$ & $\begin{array}{l}0.0059^{*} \\
(0.0022)\end{array}$ \\
\hline Observations & 656882 & 349527 & 307355 & 662254 & 352806 & 309448 \\
\hline Adjusted $R^{2}$ & 0.910 & 0.929 & 0.862 & 0.853 & 0.858 & 0.818 \\
\hline Bank × Firm F.E. & Yes & Yes & Yes & Yes & Yes & Yes \\
\hline Firm $\times$ Quarter F.E. & Yes & Yes & Yes & Yes & Yes & Yes \\
\hline
\end{tabular}

Note: ${ }^{+} p<0.1,{ }^{*} p<0.05,{ }^{* *} p<0.01,{ }^{* * *} p<0.001$. This table presents the results of OLS regressions for bank-firm level at a quarterly frequency. Interest rates are weighted by the loan shares for a given firm-bank. Bank Leverage is based on short-term debt and it is lagged and demeaned. Double-clustered standard errors by firm and time are reported in parentheses.

The lack of risk-taking could reflect the time period of our data during which banks have been highly regulated and well capitalized. Therefore, the impact of leverage differences may be minimal. Fortunately, the Y-14 data have other dimensions to identify bank risk-taking, as we turn next.

\subsection{The Role of NPLs}

Each bank reports the cumulative net charge-off (or loan loss) amount for each loan that it makes. Net charge-offs represent the dollar value of non-performing loans that banks determine they will not recover in default and will have to write-down. Net charge-offs have a distinct advantage over other common measures in the literature such as default probabilities or simple delinquency dummies. Charge-offs are net of collateral confiscation, meaning they take into account the fact that loan recovery rates are, on average, 80 percent of face value. Moreover, the losses associated with defaulted loans that are highly collateralized are generally much smaller than uncollateralized loans. Hence, net charge-offs capture this difference.

The cumulative net charge-offs are aggregated to bank-firm level and normalized by the total committed loan amount for each borrower. The charge-off ratio varies by bank-firmquarter. The charge-off results reported in Table 18 show a clear difference in the way that 
monetary policy easing impacts lending to private SMEs versus large public firms. The first column shows that private borrowers with higher charge-off rates on outstanding loans receive less credit when policy rates fall. Banks cut lending to risky private borrowers for whom they book past losses. By contrast, there is no impact on credit among public firms.

Finally, note that the charge-off results identify risk-taking from the same set of bank-firm pairs as the bank leverage results above. Taken together, the results show that high-risk banks (high leverage) cut lending more in the future to risky private borrowers based on past losses (charge-offs).

Table 18: Monetary Policy and Bank Risk-Taking via Loan Losses

\begin{tabular}{lccccc}
\hline & \multicolumn{2}{c}{ Private Firms } & & \multicolumn{2}{c}{ Public Firms } \\
\cline { 2 - 3 } \cline { 6 - 6 } & $(1)$ & $(2)$ & & $(3)$ & $(4)$ \\
& $\log (\operatorname{Loan})$ & $\log (1+i)$ & $\log (\operatorname{Loan})$ & $\log (1+i)$ \\
\hline$(\mathrm{CCO} / \text { Loan })_{q-1}$ & -0.0612 & -0.0001 & & -0.2491 & -0.0058 \\
& $(0.0553)$ & $(0.0022)$ & & $(0.2025)$ & $(0.0052)$ \\
$(\mathrm{CCO} / \text { Loan })_{q-1} \times$ MP Surprise $_{q}$ & $2.8959^{* *}$ & 0.0327 & & -1.4709 & -0.0450 \\
& $(0.8349)$ & $(0.0268)$ & & $(1.6931)$ & $(0.0446)$ \\
\hline Observations $_{\text {Adjusted } R^{2}}$ & 310023 & 297044 & & 285175 & 277986 \\
Bank $\times$ Firm F.E. & 0.933 & 0.874 & & 0.868 & 0.835 \\
Firm $\times$ Quarter F.E. & Yes & Yes & & Yes & Yes \\
\cline { 6 - 7 } & Yes & Yes & & Yes & Yes \\
\hline
\end{tabular}

Note: ${ }^{+} p<0.1,{ }^{*} p<0.05,{ }^{* *} p<0.01,{ }^{* * *} p<0.001$. This table reports OLS estimates of alternative risk measures for banks at the bank-firm level for the private firm sample (Panel A) and the public firm sample (Panel B) using quarterly data. The dependent variable in columns (1)-(4) is the natural logarithm of the total committed loan amount for a bank-firm pair; the dependent variable in columns (5)-(8) is the natural logarithm of one plus the nominal interest rate weighted for loan shares for a given bank-firm pair. The measure of bank risk is the ratio of a bank-firm's total net charge off amount divided its committed loan amount for each firm, lagged one quarter. Each column sequentially adds different fixed effects. Standard errors are double clustered at the firm and quarter levels.

\subsection{Financial Stability Risks}

Overall, our results suggest that monetary policy transmission during a period of low interest rates mostly stimulates firm credit demand rather than bank credit supply. In particular, lower policy rates raise credit demand among smaller and more leveraged private companies, do not change bank credit supply, conditional on leverage, and do not increase lending to firms with prior defaults. Thus, we do not find any evidence of risk-taking behavior by banks. However, our findings do not imply there are no financial stability risks.

We plot leverage growth among firms as a function of credit rating. The increase in leverage for public and private firms documented in Figure 11 suggests that these firms may be more likely to become delinquent in future should the economy slow, especially 
because the leverage increase among private firms is most concentrated among the riskiest borrowers. Figure 11 breaks down public and private firm leverage ratios by credit rating bins to investigate evolution over time: investment grade firms (AAA-A and BBB) and high yield firms (BBB and below). ${ }^{21}$ The ratios are normalized to 1 at the beginning of our sample period. The figure shows that after the Global Financial Crisis, most of the financial leverage increase among U.S. firms is due to rapid growth in investment grade public firms. On the contrary, for private firms, financial leverage has steadily increased only for the most risky segment - high-yield equivalent borrowers (BBB and below) - raising potential financial stability concerns. These results are consistent with Coimbra and Rey (2017), suggesting a trade-off between stimulating the economy and increasing the financial stability risks.

Finally, Figure 12 plots total debt growth among all firms in our data, split out by SME versus non-SME status. The normalized debt growth chart in panel (b) shows that total debt grew more rapidly initially for SMEs than non-SMEs in 2013, and has kept pace with debt growth among larger firms since. In sum, leverage and total debt has increased most rapidly for lower rated private borrowers and SMEs than higher rated public and large firms.

Figure 11: Leverage Growth by Rating (Base 2012Q3)

(a) Leverage by Rating: Public Firms

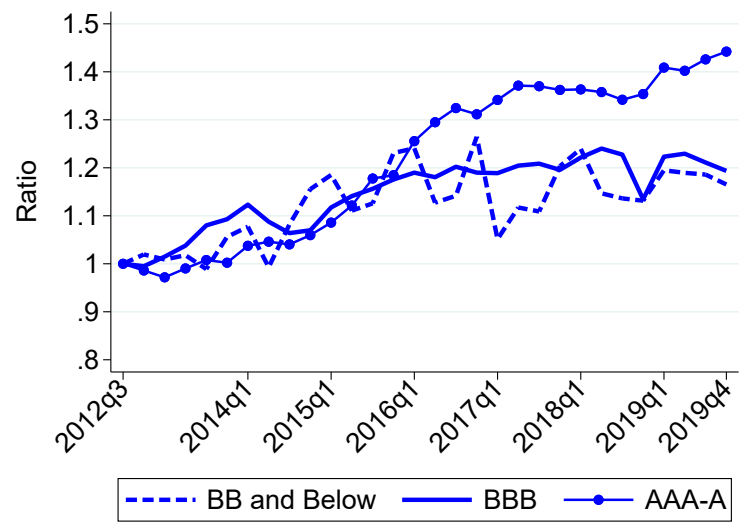

(b) Leverage by Rating: Private Firms

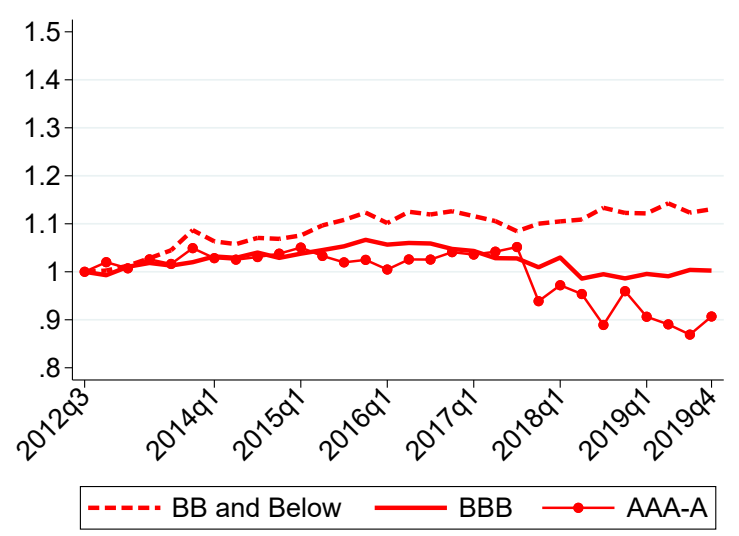

Note: The figures plot leverage ratio-defined at the sum of short- and long-term debt over total assets- normalized to 1 the 2012Q3. The left (right) panel are the leverage ratios for public (private) borrowers. Each line is the median leverage ratio for borrowers with the specified bank provided risk-rating. Source: FR Y-14Q H.1

\footnotetext{
${ }^{21}$ We use the internal ratings that each BHC assigns to its borrowers in Schedule H1 of the FR Y-14 report. To compare ratings across reporting institutions, the internal rating is converted to a standardized rating scale going from AAA (very low risk of default) to D (in default).
} 
Figure 12: Total Debt Growth for SMEs and Large Firms

(a) Total Debt in levels

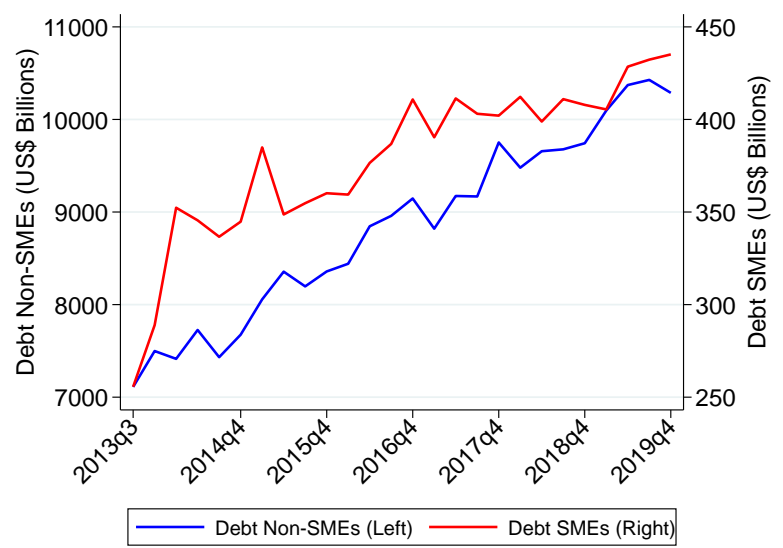

(b) Total Debt normalized

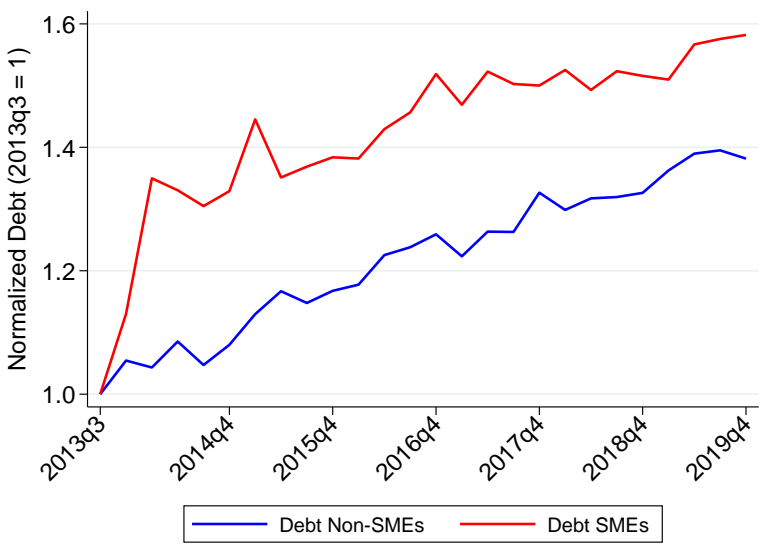

Note: This figure plots total debt amoung SMEs and non-SMEs in our sample. Total debt is the sum of short- plus long-term debt. SMEs are defined as firms with assets less than $\$ 10 \mathrm{mn}$ and or sales revenues less than $\$ 50 \mathrm{mn}$. Panel a is total debt in levels and panel b normalizes total debt to 1 in 2012Q3.

\section{Additional Analysis}

In this section we present additional dynamic analysis; investigate the effects on real outcomes such as investment, sales, and inventories; and present a back of the envelope calculation to go from 'relative' difference-in-differences estimates to 'aggregate' effects of monetary policy shocks to understand the aggregate role of leveraged SMEs. We also present a primer for the theoretical mechanism.

\subsection{Dynamic Effects of Monetary Policy on Credit Outcomes}

We estimate the dynamic response of credit outcomes to monetary policy surprises through the following local projections:

$$
\log \sum_{l \in \mathcal{L}(f, b, q+h)} Y_{f, b, q+h}(l)=\alpha_{f, b}+\alpha_{b, q}+\kappa_{h}\left(\text { High Leverage } \text { Firm }_{f} \times \mathrm{MP}_{q-k}\right)+\vartheta_{f, b, q+h}
$$

Figure 13 shows the results for the full sample of firms. The expansionary effects of monetary policy on credit quantities and prices for leveraged firms are highly persistent, lasting 10 quarters. Figures 14 and 15 decompose these effects for private and public firms. The results clearly show that the overall effects are driven by private firms, both for loan quantities and prices. An expansionary (contraction) surprise leads to more (less) borrowing and higher (lower) spreads for leveraged private firms. The results for leveraged public firms are 
insignificant.

Figure 13: Dynamic Effects of Monetary Policy on High Leveraged Firms

Loan Effect

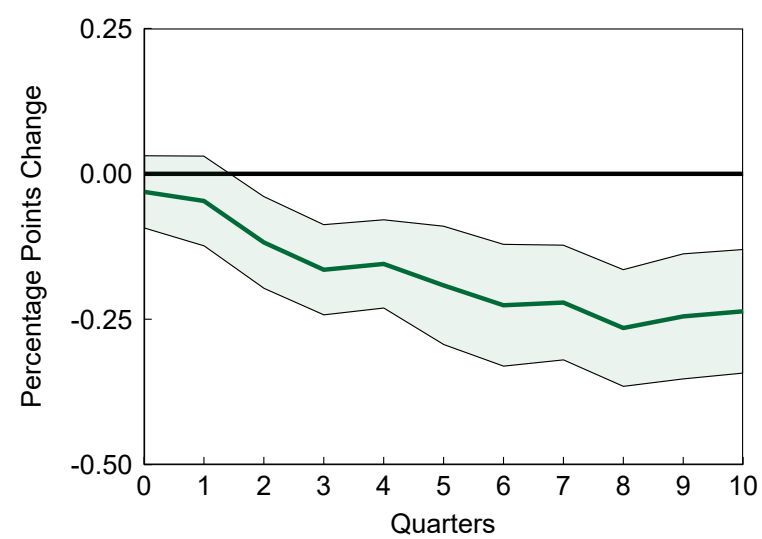

Interest Rate Effect

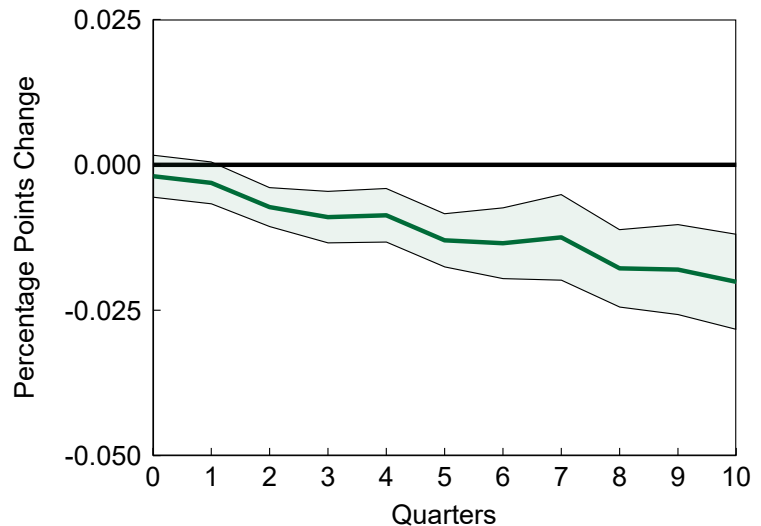

Note: The figure shows the dynamics of the interaction coefficient, $\kappa_{h}$, between firm leverage and monetary shocks over time, over quarter $h$ from equation (7). Black lines report 95 percent error bands.

Figure 14: Dynamic Effects of Monetary Policy on Loans to High Leveraged Firms by Firm Type

\section{Private Firms}

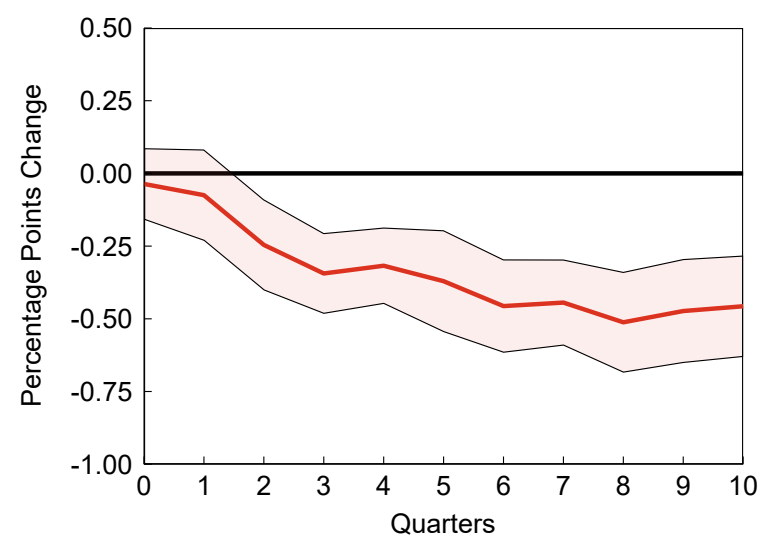

Public Firms

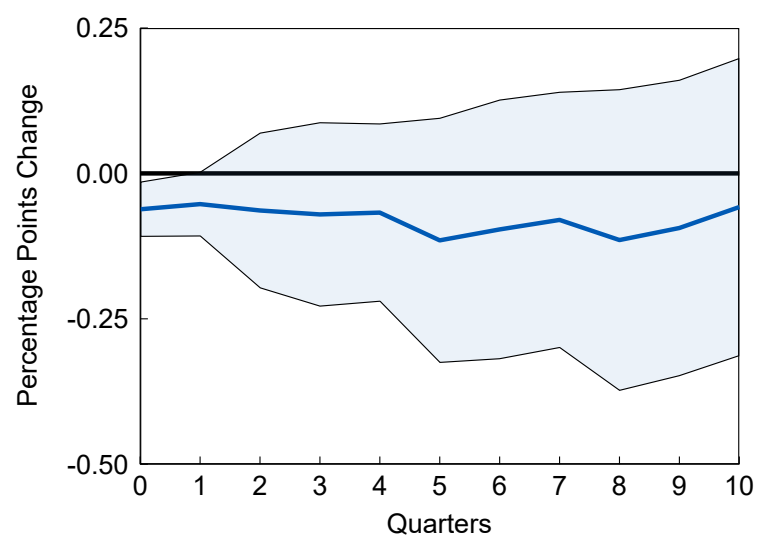

Note: The figure shows the dynamics of the interaction coefficient, $\kappa_{h}$, between firm leverage and monetary shocks over time, over quarter $h$ from equation (7), for private and public firms. Black lines report 95 percent error bands.

Figure 16 shows the dynamic triple interaction that include the leverage and SME dummy variables. The results are also persistent, especially on loan quantities. Highly leveraged SMEs borrow and pay more in response to expansionary monetary policy surprises over 10 quarters. In particular, a 1 basis point expansionary surprise causes high leveraged SMEs to borrow 0.4 percentage points (pp) more over 10 quarters relative to larger, safer firms. Credit spreads are $0.02 \mathrm{pp}$ higher for highly levered SMEs relative to others over this period. 
Figure 15: Dynamic Effects of Monetary Policy on Interest Rates of High Leveraged Firms by Firm Type

Private Firms

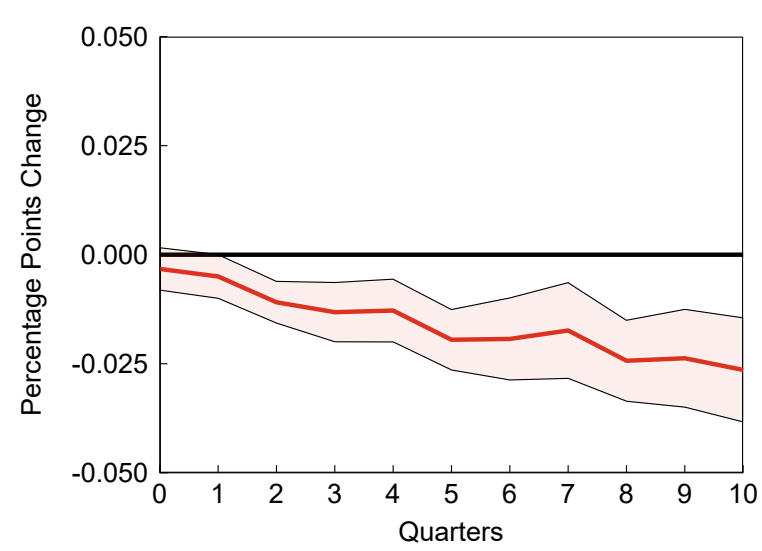

Public Firms

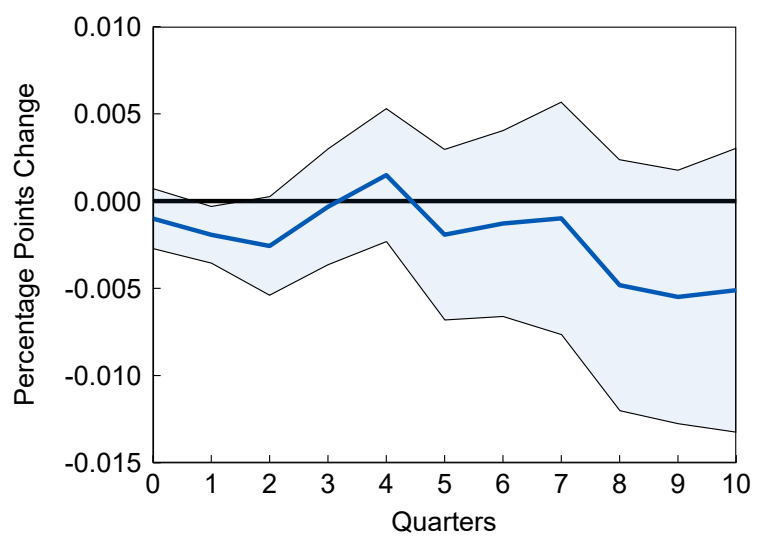

Note: The figure shows the dynamics of the interaction coefficient, $\kappa_{h}$, between firm leverage and monetary shocks over time, over quarter $h$ from equation (7), for private and public firms. Black lines report 95 percent error bands.

Figure 16: Dynamic Effects of Monetary Policy on High Leveraged SMEs

Loan Effect

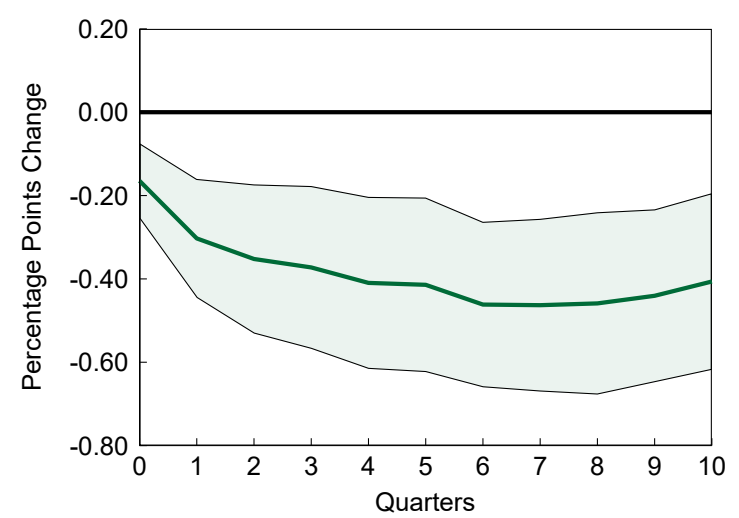

Interest Rate Effect

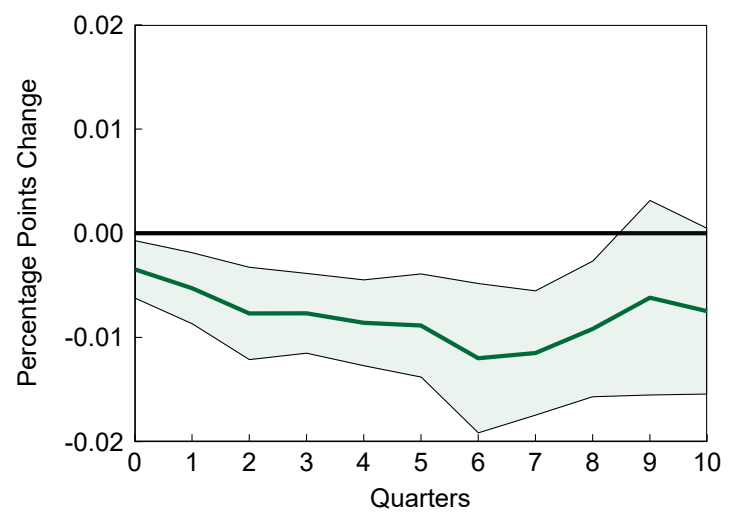

Note: The figure shows the dynamics of the interaction coefficient, $\kappa_{h}$, between firm leverage and monetary shocks over time, over quarter $h$ from equation (7), for private and public firms. Black lines report 95 percent error bands.

All these dynamic results are based on identified relative effects. If we want to know the aggregate time series patterns, we can simply plot the borrowing costs for different types of firms (credit growth has increased overall in this period). Figure 17 plots interest rates for the typical public and private borrower. Public firms borrow at lower interest rates, as shown by the blue line in the first chart on the left. The middle and right charts show median interest rates by loan and rate type (fixed versus floating rate loans and credit lines versus term loans) for private and public firms. Floating rate loans (dashed lines) track monetary 
policy rates for both borrower types. By contrast, fixed-rate loans declined both for private firms (solid gold line) and for public borrowers (solid purple line) before increasing in 2017. Figure 18 focus on rates only for new loan originations and suggest that floating rate credit line prices rose faster during rate lift-off. This might have induced a compositional change as we show in Figure 24 in the Appendix: the share of term loans among all loans has increased nearly 7 percent while the share of floating rate loans has fallen nearly 10 percent during our sample period. In order to shield our results from such compositional effects, we use all types of loans.

Figure 17: Interest rates: Fixed versus Floating

All Loans

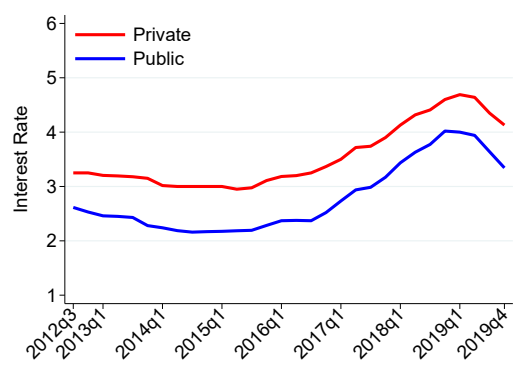

Private Firms

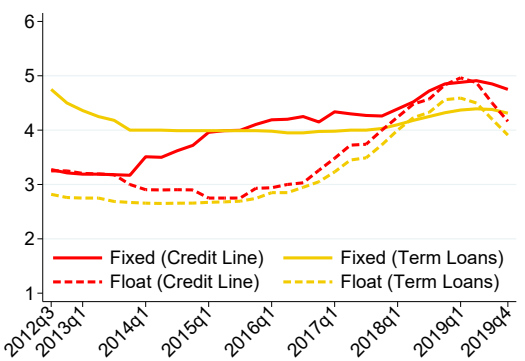

Public Firms

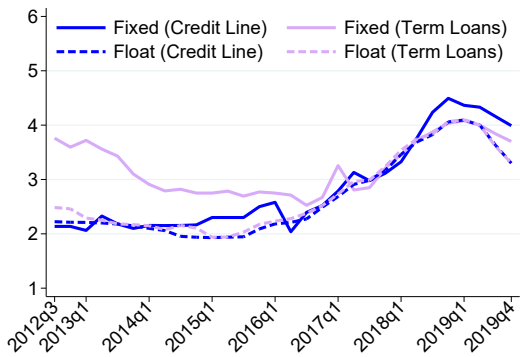

Note: The figure plots the median interest rates (in percent). The first chart plots interest rates for all loans for private borrowers in red and public borrowers in blue. The middle chart plots median interest rate for private borrowers for different loan types and rates. Solid lines plot rate on fixed rate loans (credit lines in red and term loans in gold). The dashed lines are rate on floating rate loans (credit lines in red and term loans in gold). The right chart plots median interest rate for public borrowers for different loan types and rates. Solid lines plot rate on fixed rate loans (credit lines in blue and term loans in purple). The dashed lines are rate on floating rate loans (credit lines in blue and term loans in purple). Source: FR Y-14Q H.1.

\subsection{Aggregation}

In this section, we explore the quantitative effects in relation to the literature that uses aggregate data on credit growth and same MP shocks. This literature finds a 30 percent increase in credit growth with one std deviation increase in MP shocks, though their shocks are much larger given their long time series data. ${ }^{22}$

We start by running the following regression, without firm-time or bank-time fixed effects to mimic the regressions using aggregate data. We then predict credit growth:

$$
\log \sum_{l \in \mathcal{L}(f, b, q)} Y_{f, b, q}(l)=\alpha_{f, b}+\kappa_{0}^{\mathrm{Agg}} \mathrm{MP}_{q}^{M A}+\vartheta_{f, b, q}
$$

\footnotetext{
${ }^{22}$ See for example Gertler and Karadi (2015).
} 
Figure 18: Interest rates on New Originations

Private Firms

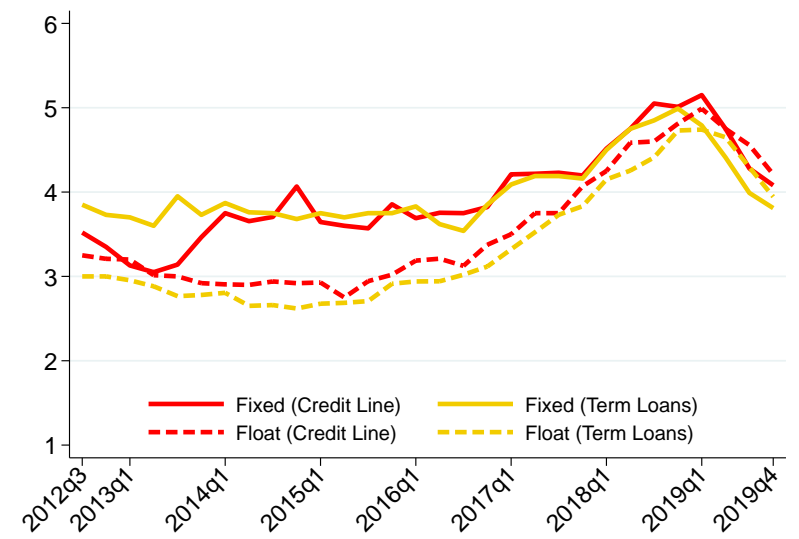

Public Firms

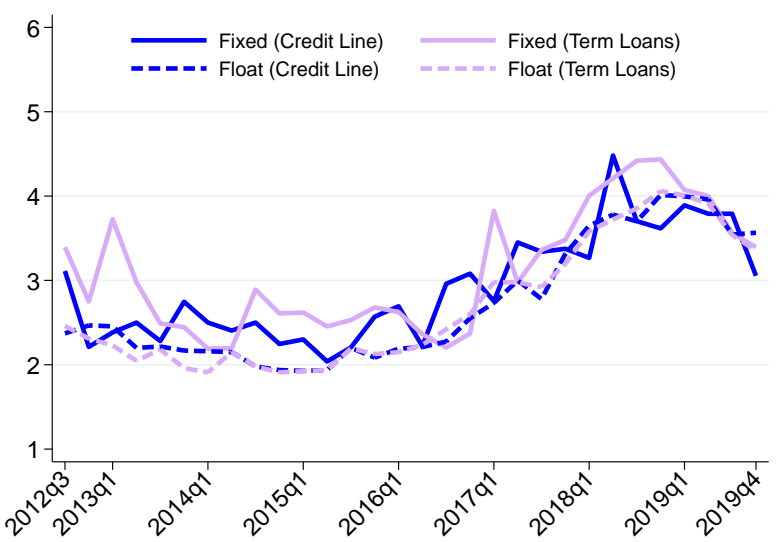

Note: The figure plots the median interest rate (in percent) for new loan origination broken out by credit lines, term loans with fixed versus floating rates. The chart on the left plots the various loan rates for for private borrowers on the left and public borrowers on the right. The solid lines are fixed rate loans and the dashed lines are floating rate loans. Source: FR Y-14Q H.1. Source: FR Y-14Q H.1.

$$
\Longrightarrow \log \widehat{Y}_{f, b, q}=\hat{\alpha}_{f, b}+\hat{\kappa}_{0}^{\mathrm{Agg}} \mathrm{MP}_{q}^{M A}
$$

Taking difference with respect to $q-1$

$$
d \log \widehat{Y_{f, b, q}}=\hat{\kappa}_{0}^{\mathrm{Agg}} \Delta \mathrm{MP}_{q}^{M A}
$$

Multiplying each side by $\omega_{f, b, q-1}$ such that $\sum_{f, b} \omega_{f, b, q-1}=1$ and adding across all bank-firm $(b, q)$ pairs at time $q$

$$
\begin{aligned}
\omega_{f, b, q-1} \log \widehat{Y_{f, b, q}} & =\omega_{f, b, q-1} \hat{\kappa}_{0}^{\mathrm{Agg}} \Delta \mathrm{MP}_{q}^{M A} \\
d \widehat{\log Y_{q}} & =\hat{\kappa}_{0}^{\mathrm{Agg} \Delta \mathrm{MP}_{q}^{M A}} \\
\left.\frac{\text { Average }\left\{d \widehat{\left.\log Y_{q}\right\}}\right.}{\text { Average }\{\text { Agg. Loan Growth }}\right\} & =0.03
\end{aligned}
$$

The last equation uses series on the observed MP surprises during our sample and shows these surprises can explain 3 percent of the observed credit growth (used on the denominator). This is in the ballpark of the literature that uses 5 times the MP surprises we use on average (25 basis points versus 5 basis points) and explain 30 percent of the credit growth.

The important question for us is what fraction of the aggregate 3 percent is driven by 
high leverage firms? To estimate that number, we run:

$$
\begin{gathered}
\log \sum_{l \in \mathcal{L}(f, b, q)} Y_{f, b, q}(l)=\alpha_{f, b}+\kappa_{0} \mathrm{MP}_{q}^{M A}+\kappa_{1} \times \text { High Leverage Firm } \\
\Longrightarrow \widehat{M P}_{q}^{M A}+\vartheta_{f, b, q} \\
\Longrightarrow d \log Y_{f, b, q}=\hat{\kappa}_{0} \Delta \mathrm{MP}_{q}^{M A}+\hat{\kappa}_{1} \times \text { High Leverage Firm } \mathbf{F i n}_{f} \times \Delta \mathrm{MP}_{q}^{M A}
\end{gathered}
$$

Multiplying each side by $\omega_{f, b, q-1}$ such that $\sum_{f, b} \omega_{f, b, q-1}=1$ and adding over $(f, b)$

$$
d \log \widehat{Y}_{q}=\left(1-\omega_{q-1}^{H L}\right) \hat{\kappa}_{0} \Delta \mathrm{MP}_{q}^{M A}+\underbrace{\omega_{q-1}^{H L}}_{\text {Share of Total Loans by High Leverage Firms }}\left(\hat{\kappa}_{0}+\hat{\kappa}_{1}\right) \Delta \mathrm{MP}_{q}^{M A}
$$

Hence, we can show that 60 percent of the observed credit growth due to MP shocks are driven by high leverage firms. Thus, transmission of policy via high leveraged firms is economically significant.

$$
\frac{\operatorname{Avg}\left(\omega_{q-1}^{H L}\left(\hat{\kappa}_{0}+\hat{\kappa}_{1}\right) \Delta \mathrm{MP}_{q}^{M A}\right)}{\operatorname{Avg}\left(d \log \widehat{Y}_{q}\right)}=0.6
$$

\subsection{Investment, Sales and Inventories}

In this section, we investigate the heterogeneous impact of monetary policy transmission on real outcomes, namely investment, sales, and inventories.

We use two definitions of investment in the absence of CAPEX for private firms. We define investment for each firm as the change in the log of fixed assets at the firm level. We also use the DHS (Davis, Haltiwanger, and Schuh, 1996) measure to calculate the change in fixed assets that takes care of outliers. Given the definition of investment, the regressions are at the firm-time level and include one-way firm and time fixed effects. Leverage is measured as in all previous regressions by a time-invariant dummy variable.

Table 19 shows the results for the different definitions of investment. A surprise monetary policy easing results in increased investment among highly levered firms, consistent with our previous results on credit growth. The relative impact suggests that high leveraged firms increase investment 0.3 percent more than low leveraged firms as a result of a 100 basis point surprise shock to policy rates. 
Table 19: Leverage and Investment

\begin{tabular}{lcc}
\hline & $\Delta \log ($ FixedAssets $)$ & $D H S$ \\
\hline High Leverage Firm $\times$ MP Surprise $_{q}$ & $-0.0030^{* * *}$ & $-0.0022^{* * *}$ \\
& $(0.0008)$ & $(0.0006)$ \\
\hline Observations & $1,750,991$ & $1,642,836$ \\
Adjusted $R^{2}$ & 0.0707 & 0.0767 \\
Quarter F.E. & Yes & Yes \\
Firm F.E. & Yes & Yes \\
\hline
\end{tabular}

Note: ${ }^{+} p<0.1,{ }^{*} p<0.05,{ }^{* *} p<0.01,{ }^{* * *} p<0.001$. The table presents the results of OLS regressions at the firm-time level. The dependent variable $\Delta \log ($ FixedAssets $)$ is a measure of investment defined by the change in natural logarithm of fixed assets. The dependent variable $D H S=\frac{F A_{t}-F A_{t-1}}{.5 F A_{t}-F A_{t-1}}$ developed by Davis, Haltiwanger, and Schuh (1996). High Leverage Firm is a dummy equal to one if the firm leverage is above the sample median and is based on short-term debt. Standard errors are clustered at the firm level, and include quarter and firm fixed effects.

Next, following Gertler and Gilchrist (1994), we investigate the behavior of sales and inventories. They show that small manufacturing firms sales and inventories are more sensitive to monetary policy tightening episodes. Intuitively, a decline in sales for financially constrained firms impedes their ability to accumulate inventories compared to large firms who can borrow to continue offering products. We confirm their results from a broader set of SMEs in the U.S. economy during an expansion.

We estimate both dynamic local projections and OLS panels for the impact of monetary policy shocks on SME sales, inventories, and the inventory-to-sales ratio. Recall that our sample period is mostly characterized by monetary easing, so we expect to see higher sales. Given the fact that SMEs use sales and inventory to access credit, monetary policy should loosen their constraints and allow them to accumulate additional inventory through expanded borrowing capacity.

The local projections are estimated with the following equation:

$$
\log Y_{f, q+h}(l)=\alpha_{f}+\alpha_{q}+\kappa_{h}\left(\text { High Leverage } \text { Firm }_{f} \times \mathbf{S M E}_{f} \times \mathrm{MP}_{q-k}\right)+\vartheta_{f, q+h}
$$

The results, shown in Figure 19, show that monetary easing (negative monetary policy shocks) result in higher sales. These responses are confirmed in the OLS estimates of column (3) of Table 20. The same table shows that these results are driven by leveraged SMEs as shown in column (4). The inventory results are shown in columns (1) and (2). Monetary policy easing results in highly leveraged SMEs, who mostly use accounts receivables, inventory and blanket liens as collateral, to have higher sales and inventory growth. Furthermore, column 
Figure 19: Dynamic effects of monetary policy shocks on SME sales

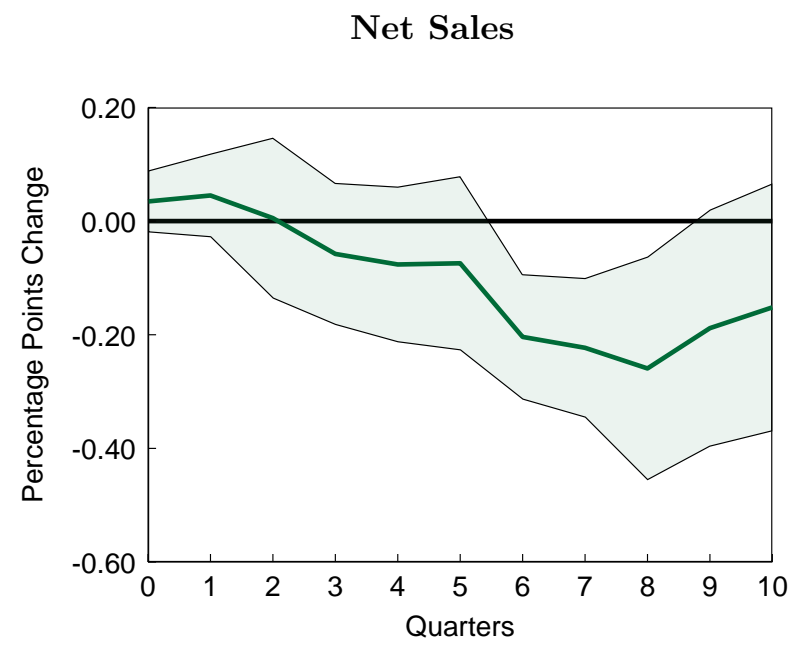

Note: The figure shows the dynamics of the triple interaction coefficient of, $\kappa_{h}, \mathrm{SME} \times \mathrm{MP} \times$ Leverage over quarter $h$, from equation (8).

Table 20: The Effects of Monetary Policy on Sales and Inventories

\begin{tabular}{|c|c|c|c|c|c|}
\hline & \multicolumn{2}{|c|}{ Inventory } & \multicolumn{2}{|c|}{ Sales } & \multirow{2}{*}{$\frac{\text { Inventory to Sales Ratio }}{(5)}$} \\
\hline & $(1)$ & $(2)$ & $(3)$ & $(4)$ & \\
\hline $\mathrm{SME} \times \mathrm{MP}$ Surprise $_{q}$ & $\begin{array}{c}-0.0485^{* * *} \\
(0.016)\end{array}$ & $\begin{array}{l}0.0196 \\
(0.027)\end{array}$ & $\begin{array}{c}-0.0753^{* * *} \\
(0.012)\end{array}$ & $\begin{array}{r}-0.0077 \\
(0.020)\end{array}$ & $\begin{array}{c}4.2500^{* * *} \\
(0.368)\end{array}$ \\
\hline High Leverage Firm $\times$ MP Surprise $_{q}$ & & $\begin{array}{c}0.1435^{* * *} \\
(0.024)\end{array}$ & & $\begin{array}{c}0.1173^{* * *} \\
(0.021)\end{array}$ & $\begin{array}{c}1.6240^{* * *} \\
(0.382)\end{array}$ \\
\hline High Leverage Firm $\times$ SME $\times$ MP Surprise $_{q}$ & & $\begin{array}{c}-0.1087^{* * *} \\
(0.034)\end{array}$ & & $\begin{array}{c}-0.1102^{* * *} \\
(0.025)\end{array}$ & $\begin{array}{l}-2.5280^{* * *} \\
(0.410)\end{array}$ \\
\hline Observations & 1330266 & 1330266 & 1821646 & 1821646 & 1779287 \\
\hline$R^{2}$ & 0.0543 & 0.0543 & 0.0507 & 0.0507 & 0.6984 \\
\hline Firm F.E. & Yes & Yes & Yes & Yes & Yes \\
\hline Quarter F.E. & Yes & Yes & Yes & Yes & Yes \\
\hline
\end{tabular}

Note: ${ }^{+} p<0.1,{ }^{*} p<0.05,{ }^{* *} p<0.01,{ }^{* * *} p<0.001$. This table presents results for the OLS regressions on firm-time level data for the full sample. The dependent variable in columns (1) and (2) is the growth rate of firm balance-sheet inventory defined as the difference in natural logarithm q-o-q; the dependent variable in columns (3) and (4) is the growth rate of firm sales defined as the difference in natural logarithm q-o-q; the dependent variable in columns (5) and (6) is the inventory to sales ratio. SME is a dummy indicating whether a firm is a SME (less than 50 millions in net sales) or non-SME. Standard errors are clustered by firm-time and are reported in parentheses.

(5) shows that leveraged SME inventory-to-sales ratios rise after monetary expansions. This suggests that their inventory response is stronger than the sales response, which buttresses the notion that their financial constraints are relaxed, allowing them to accumulate more inventory. Another way to read this result is that, leveraged SMEs inventories fall more than sales during monetary contractions as these firms contract more and try to smooth this out using inventories. 


\subsection{A Primer on the Mechanism}

In this section we interpret the results from the lens of a model. Recall that expansionary monetary policy works mostly via credit demand of private SMEs whose borrow against earnings and operations-based collateral. We argue that expansionary policy increases the value of this type of collateral most among all collateral types. We show below how this type of collateral expands the borrowing capacity of risky firms by increasing net worth and lowering default risk and flattening the curve for supply of funds.

Standard macroeconomic theory conceptualizes firm financial frictions in one of two ways. The first follows Bernanke and Gertler (1989) and Bernanke, Gertler, and Gilchrist (1996). These costly-state verification models do not feature collateral constraints but feature default. Monetary policy relaxes an agency friction by increasing net worth and lowering default risk. The second framework pioneered by Kiyotaki and Moore (1997) introduces a collateral constraint that specifies firms may borrow up to a fraction of their capital. However, all debt in this class of models is risk-free because collateral constraints bind and firms cannot borrow more than the value of what they can repay in the future. In the micro contracting literature, there is a clear relation between pledging collateral and default risk, where high default risk firms have to pledge collateral and their debt is limited by the liquidation value of this collateral; in a default event, the re-sale value of the collateral provides insurance to the lender. Darst and Refayet (2018) offer a simplified 2-period model that features both endogenous default and a restriction on the value of promises firms make today based on the value of what they can produce tomorrow. However, we are not aware of any full-fledged macro model that incorporates both collateral constraints with risky debt.

Our results embed both effects. A monetary expansion relaxes SMEs collateral constraint because the constraint is based on earnings, which also improves their ability to repay, leading to lower default risk. The recent heterogeneous firm new Keynesian framework of Ottonello and Winberry (2020) features default, but does not have a collateral constraint. Nevertheless, a simple modification of their framework is suitable to interpret our empirical results.

Panel (a) in Figure 20 is the same as Ottonello and Winberry (2020), which shows that a low leverage/default risk firm operates on the flat portion of the marginal cost for investment curve. Equilibrium investment is determined by the intersection of the marginal cost and benefit curves, $k_{0}^{\prime *}$. A monetary expansion, shown by the shifts to the red lines, raises both marginal cost and benefit curves. The new investment level is given by $k_{1}^{\prime *}$.

Risky/high leverage firms operate on the upward sloping part of the marginal cost curve shown in panel (b). Expansionary monetary policy increases the price of capital shifting

the marginal cost curve up. The movement from $k_{1}^{\prime C}$ to $k_{2}^{\prime C}$ captures this pure cost increase. Additionally, expansionary policy extends the flat portion of marginal cost curve due to a 
higher net worth. Higher net worth implies that firms can repay debt over a larger state-space. Moreover, expansionary policy also flattens the marginal cost cure because it increases the value of the earnings-based collateral used to secure the loan. As shown in the figure, the use of earnings and operations-based collateral can amplify this effect by significantly flattening the cost curve leading to larger relative changes in risky firm investment shown by $k_{5}^{\prime C}$. This simple modification captures the essence of our results.

Figure 20: Mechanism

(a) Risk-Free Firm

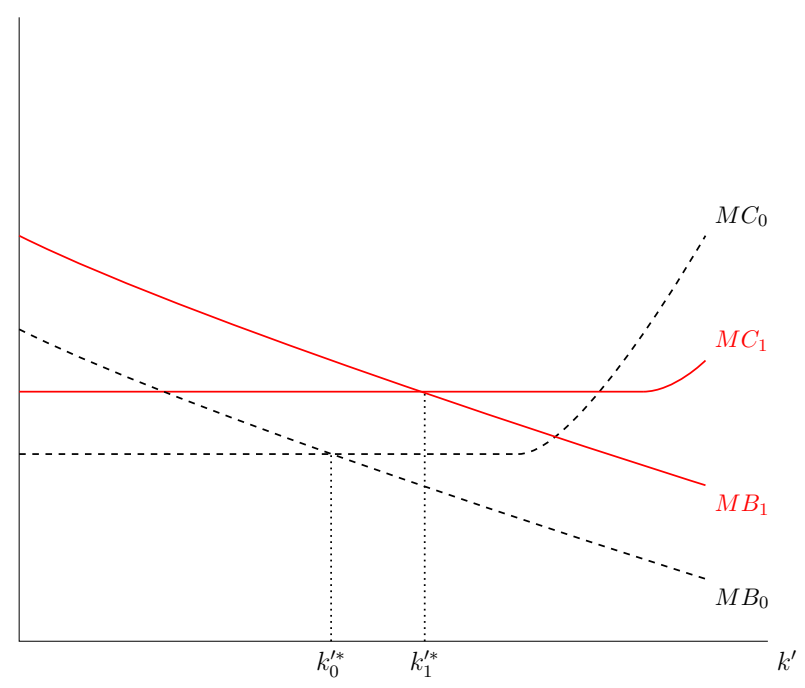

(b) Risky Firm

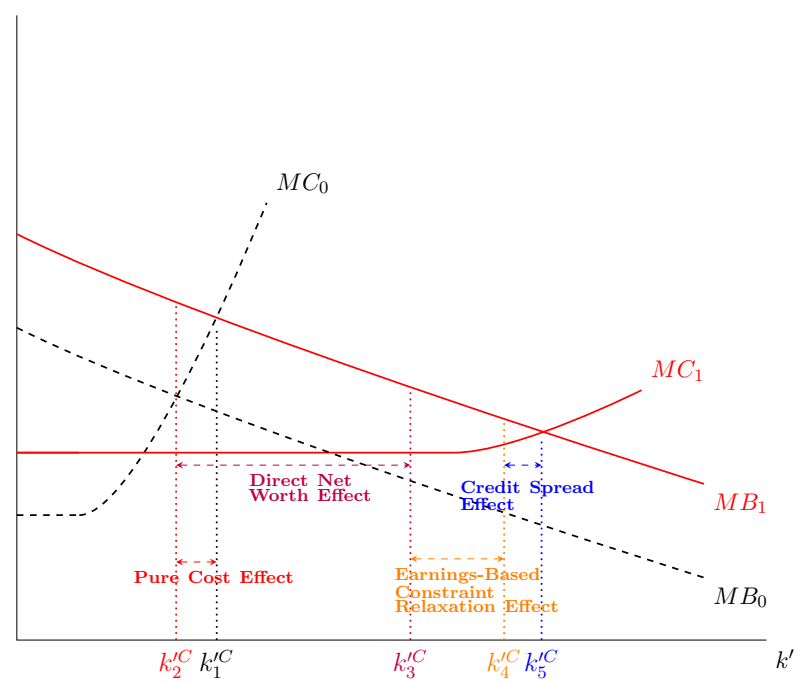

\section{Conclusion}

We use confidential administrative data, matched at firm-bank-loan-quarter level, to explore how monetary policy transmits in an economy with heterogeneous firms and banks. We show that, compared to large public firms, SMEs are financially constrained, bank dependent, and pledge different forms of collateral to borrow. Monetary expansions increase leveraged-SME credit demand but do not increase the credit supplied by risky banks to SMEs. Since most firms in the U.S. are SMEs, our results on all U.S. firms - private and publicly listed combined - are driven by SMEs. As a result, monetary expansions lead to higher credit, sales growth, and investment in the aggregate economy due to response of these firms to policy shocks, underlying the important role for heterogeneity for aggregate outcomes. The effects on leveraged SMEs can explain 60 percent of the aggregate credit growth as a result of monetary expansions.

Our results show a dual-role of collateral: Its normal time effect as a measure of risk versus access to finance depends on firm size. The relation between collateral and risk is 
positive for large firms but negative for SMEs. Hence, posting collateral for large firms, who typically borrow unsecured, is a sign of distress. By contrast, posting collateral for SMEs is associated with more credit and lower spreads. This one-to-one mapping between collateral and firm size carries over to types of collateral and determines how financial constraints relax and/or tightening during monetary policy shocks. For example, due to the use of earnings and operations based collateral, leveraged-SME credit demand and borrowing capacity increase relatively more than all other firms during monetary expansions. Lower policy rates relax this type of collateral constraint, raise the ability to pay debt, and lower default risk. We find no similar effects for large publicly listed firms.

Overall, SMEs' increased borrowing and investment demand drives the aggregate effects of monetary expansions, as argued by Bernanke and Gertler (1995). These authors show that during normal times, the effects on smaller borrowers are usually more important for monetary policy transmission than the effects on bank capital and bank borrowing costs. We document novel evidence for the mechanism behind this argument: smaller firms' financial constraints respond more to monetary policy shocks because they borrow using earnings and operations based collateral. There might still be a trade-off between stimulating the economy in the short-run and future financial stability because lower policy rates coincide with more borrowing by leveraged SMEs.

A recent literature argues that the general equilibrium effects of firm investment are critical to understanding monetary policy transmission (Auclert, Rognlie, and Straub, 2020). Our results buttress this reasoning and suggest that the effectiveness of the investment channel may depend on the firm size distribution and the different types of collateral used to obtain financing to maintain and expand operations. 


\section{References}

Auclert, Adrien. 2019. "Monetary Policy and the Redistribution Channel." American Economic Review 109 (6): 2333-67. 10.1257/aer.20160137.

Auclert, Adrien, Matthew Rognlie, and Ludwig Straub. 2020. "Micro Jumps, Macro Humps: Monetary Policy and Business Cycles in an Estimated HANK Model." Working Paper 26647, National Bureau of Economic Research (NBER). 10.3386/w26647.

Benmelech, Efraim, and Nittai K. Bergman. 2012. "Credit Traps." American Economic Review 102 (6): 3004-32. 10.1257/aer.102.6.3004.

Berger, Allen N., W. Scott Frame, and Vasso Ioannidou. 2016. "Reexamining the Empirical Relation Between Loan Risk and Collateral: The Roles of Collateral Liquidity and Types." Journal of Financial Intermediation 2628 - 46. https://doi.org/10.1016/j.jfi.2015.11.002.

Berger, Allen N., and Gregory F. Udell. 1990. "Collateral, Loan Quality and Bank Risk." Journal of Monetary Economics 25 (1): 21-42. https://doi.org/10.1016/0304-3932(90) 90042-3.

Bernanke, Ben, and Mark Gertler. 1989. "Agency Costs, Net Worth, and Business Fluctuations." The American Economic Review 79 (1): 14-31, http://www.jstor.org/ stable/1804770.

Bernanke, Ben, Mark Gertler, and Simon Gilchrist. 1996. "The Financial Accelerator and the Flight to Quality." The Review of Economics and Statistics 78 (1): 1-15, http: //www.jstor.org/stable/2109844.

Bernanke, Ben S., and Mark Gertler. 1995. "Inside the Black Box: The Credit Channel of Monetary Policy Transmission." Journal of Economic Perspectives 9 (4): 27-48. 10.1257/jep.9.4.27.

Cloyne, James, Clodomiro Ferreira, Maren Froemel, and Paolo Surico. 2022. "Monetary Policy, Corporate Finance and Investment." Forthcoming, Journal of the European Economic Association.

Coimbra, Nuno, and Hélène Rey. 2017. "Financial Cycles with Heterogeneous Intermediaries." Working Paper 23245, National Bureau of Economic Research (NBER). 10.3386/w23245.

Darst, Matthew, Ehraz Refayet, and Alexandros Vardoulakis. 2020. "Banks, Non-Banks, and Lending Standards." Finance and Economics Discussion Series 2020-086: Washington: 
Board of Governors of the Federal Reserve System. https://doi.org/10.17016/FEDS.2020. 086.

Darst, R. Matthew, and Ehraz Refayet. 2018. "Credit Default Swaps in General Equilibrium: Endogenous Default and Credit-Spread Spillovers." Journal of Money, Credit and Banking 50 (8): 1901-1933. https://doi.org/10.1111/jmcb.12507.

Davis, Steven, John Haltiwanger, and Scott Schuh. 1996. "Small Business and Job Creation: Dissecting the Myth and Reassessing the Facts." Small Business Economics 8 (4): 297-315, https://link. springer. com/article/10.1007/BF00393278.

Dell'Ariccia, Giovanni, Luc Laeven, and Gustavo A. Suarez. 2017. "Bank Leverage and Monetary Policy's Risk-Taking Channel: Evidence from the United States." The Journal of Finance 72 (2): 613-654. 10.1111/jofi.12467.

Dinlersoz, Emin, Sebnem Kalemli-Ozcan, Henry Hyatt, and Veronika Penciakova. 2018. "Leverage over the Life Cycle and Implications for Firm Growth and Shock Responsiveness." Working Paper 25226, National Bureau of Economic Research (NBER). 10.3386/w25226.

Drechsel, Thomas. 2022. "Earnings-Based Borrowing Constraints and Macroeconomic Fluctuations." Forthcoming, American Economic Journal: Macroeconomics.

Eisfeldt, Andrea L., and Adriano A. Rampini. 2008. "Leasing, Ability to Repossess, and Debt Capacity." The Review of Financial Studies 22 (4): 1621-1657. 10.1093/rfs/hhn026.

Gertler, Mark, and Simon Gilchrist. 1994. "Monetary Policy, Business Cycles, and the Behavior of Small Manufacturing Firms." The Quarterly Journal of Economics 109 (2): 309-340. 10.2307/2118465.

Gertler, Mark, and Peter Karadi. 2015. "Monetary Policy Surprises, Credit Costs, and Economic Activity." American Economic Journal: Macroeconomics 7 (1): 44-76. 10.1257/ mac.20130329.

di Giovanni, Julian, Şebnem Kalemli-Özcan, Mehmet Fatih Ulu, and Yusuf Soner Baskaya. 2021. "International Spillovers and Local Credit Cycles." The Review of Economic Studies 89 (2): 733-773. 10.1093/restud/rdab044.

Gopinath, Gita, Sebnem Kalemli-Ozcan, Loukas Karabarbounis, and Carolina VillegasSanchez. 2017. "Capital Allocation and Productivity in South Europe." The Quarterly Journal of Economics 132 (4): 1915-1967. 10.1093/qje/qjx024. 
Ivashina, Victoria, Luc Laeven, and Enrique Moral-Benito. 2022. "Loan Types and the Bank Lending Channel." Journal of Monetary Economics 126 171-187. https://doi.org/10.1016/ j.jmoneco.2021.11.006.

Jeenas, Priit. 2019. "Firm Balance Sheet Liquidity, Monetary Policy Shocks, and Investment Dynamics." Working Paper, https://drive.google.com/file/d/ 1-Rx-odahU9gOBFS4bsYxrim-2-G1KEC5/view.

Jiménez, Gabriel, Steven Ongena, José-Luis Peydró, and Jesús Saurina. 2014. "Hazardous Times for Monetary Policy: What Do Twenty-Three Million Bank Loans Say about the Effects of Monetary Policy on Credit Risk-taking?" Econometrica 82 (2): 463-505, http://www. jstor.org/stable/24029266.

Kalemli-Ozcan, Sebnem. 2019. "U.S. Monetary Policy and International Risk Spillovers." Technical report, Proceedings from Jackson Hole Symposium, https://www . kansascityfed.org/Jackson\%20Hole/documents/6951/Ozcan_JH2019.pdf.

Kaplan, Greg, Benjamin Moll, and Giovanni L. Violante. 2018. "Monetary Policy According to HANK." American Economic Review 108 (3): 697-743. 10.1257/aer.20160042.

Kermani, Amir, and Yueran Ma. 2020. "Two Tales of Debt." Working Paper 27641, National Bureau of Economic Research. 10.3386/w27641.

Kiyotaki, Nobuhiro, and John Moore. 1997. "Credit Cycles." Journal of Political Economy 105 (2): 211-248, http://www.jstor.org/stable/10.1086/262072.

Kiyotaki, Nobuhiro, John Moore, and Shengxing Zhang. 2021. "Credit Horizons." Working Paper 28742, National Bureau of Economic Research (NBER). 10.3386/w28742.

Lian, Chen, and Yueran Ma. 2020. "Anatomy of Corporate Borrowing Constraints." The Quarterly Journal of Economics 136 (1): 229-291. 10.1093/qje/qjaa030.

Luck, Stephan, and Joao Santos. 2019. "The Value of Collateral in Loan Contracts." working paper, SSRN, http://dx.doi.org/10.2139/ssrn.3467316.

Miranda-Agrippino, Silvia, and Hélène Rey. 2020. "U.S. Monetary Policy and the Global Financial Cycle." The Review of Economic Studies 87 (6): 2754-2776. 10.1093/restud/ rdaa019.

Ottonello, Pablo, and Thomas Winberry. 2020. "Financial Heterogeneity and the Investment Channel of Monetary Policy." Econometrica 88 (6): 2473-2502. https://doi.org/10.3982/ ECTA15949. 
Paligorova, Teodora, and Joao A.C. Santos. 2017. "Monetary Policy and Bank Risk-taking: Evidence from the Corporate Loan Market." Journal of Financial Intermediation 3035 49. https://doi.org/10.1016/j.jfi.2016.11.003.

Rajan, Raghuram G. 2005. "Has Financial Development Made the World Riskier?" The Greenspan Era: Lessons for the Future.(Kansas City: Federal Reserve Bank of Kansas City, available at:, http://www.kc.frb.org/publicat/sympos/2005/pdf/Rajan2005.pdf.

Rauh, Joshua D., and Amir Sufi. 2010. "Capital Structure and Debt Structure." The Review of Financial Studies 23 (12): 4242-4280. 10.1093/rfs/hhq095.

Romer, Christina D., and David H. Romer. 2004. "A New Measure of Monetary Shocks: Derivation and Implications." American Economic Review 94 (4): 1055-1084. 10.1257/ 0002828042002651.

Stiglitz, Joseph E., and Andrew Weiss. 1981. "Credit Rationing in Markets with Imperfect Information." The American Economic Review 71 (3): 393-410, http://www.jstor.org/ stable/1802787.

Tenreyro, Silvana, and Gregory Thwaites. 2016. "Pushing on a String: US Monetary Policy Is Less Powerful in Recessions." American Economic Journal: Macroeconomics 8 (4): 43-74. 10.1257/mac.20150016.

Wong, Arlene. 2019. "Refinancing and The Transmission of Monetary Policy to Consumption." Working Paper. https://static1.squarespace.com/static/576576adbe659449f97e0d35/t/ 5ce1f9f23fdc1e00014f3d22/1558313459256/Paper_AERrevision_0519.pdf. 


\section{Online Appendix (For Online Publication Only)}

\section{A Variable Definitions}

\begin{tabular}{ll}
\hline Variable & Definition \\
\hline Bank leverage & It is calculated both as short-term debt as a fraction of total assets and as total liabilities as a fraction of total assets. \\
Firm leverage & It is calculated both as short-term debt as a fraction of total assets and as total liabilities as a fraction of total assets. \\
Collateral type & Real estate \\
& Fixed assets \\
& Cash and marketable securities \\
& Blanket lien and others \\
& Unsecured \\
& \\
Probability of future default & It is dummy equal to one if the firm defaults at any point in time in the future. \\
Charge-offs & It is calculated as the maximum cumulative net charge-offs by bank weighted by the bank's commitments. \\
Charge-offs & It is calculated as the total cumulative net charge-offs by firm. \\
Charge-offs & It is calculated as the average cumulative net charge-offs by loan. \\
\hline
\end{tabular}

\section{B Data Details}

\section{B.1 FR Y-14Q Schedule H.1}

The FR Y-14Q report collects detailed information on bank holding companies' (BHCs), savings and loan holding companies' (SLHCs), and U.S. intermediate holding companies' (IHCs) of foreign bank organizations (FBOs) on a quarterly basis. The data are collected as part of the Federal Reserve's Comprehensive Capital Analysis and Review (CCAR) for BHCs, SLHCs and IHCs with at least $\$ 50$ billion ( $\$ 100$ billion starting from 2019) in total assets. $^{23}$ The banks that submit FR Y-14Q data since 2012 comprise over 85 percent of the total assets in the U.S. banking sector.

For our study, we use the Wholesale Risk Schedule, or H.1. Schedule, which collects loan level data on corporate loans and leases together with corporates' balance sheets. The H.1 Schedule has two sections: (1) Loan and Obligor Description section, which collects information related to the firm and the loan itself; and (2) Obligor Financial Data section, which collects data related to the financial health (balance sheet and income statement) of the firm. Hence we also have time varying information on bank and firm balance sheets.

\footnotetext{
${ }^{23}$ The assessment is conducted annually and consists of two related programs: Comprehensive Capital Analysis and Review and Dodd-Frank Act stress testing (DFAST).
} 
Banks report details on corporate loans and leases that are either held-for-investment (HFI) or held-for-sale (HFS) in the loan book at each quarter end. Loans and leases with HFI designation are those that the bank has the "intent and ability to hold until the foreseeable future or until maturity or payoff." Loans and leases that are HFS are those that the bank intends or expects to sell at some indefinite date in the future. Both HFI and HFS loans and leases are categorically distinct from those that are reported as trading assets. Trading assets of banks are not reported on FR Y-14 Schedule H.1 and are instead reported on Schedule B (Securities Schedule). The vast majority of loans in the FR Y-14 data (on average 98 percent by dollar amount) are designated as HFI.

The population of loans is reported at the credit facility level (loan level) and is limited to commercial and industrial loans with a committed balance greater than or equal to $\$ 1$ million. ${ }^{24}$ Each facility is reported separately when borrowers have multiple facilities from the same bank. The facility level information includes total committed and utilized amounts, pricing and spread information, origination and maturity dates, and information on the value and type of underlying collateral. We use facility and loan interchangeably throughout the paper.

The total committed value of the loans reported on the H.1 Schedule as of 2019Q4 is nearly $\$ 3.3$ trillion. $^{25}$ To get a sense for what fraction of total U.S. C\&I lending our data comprise, we compare it to what is reported by the universe of BHCs, in the aggregate form, on the FR Y-9C (schedules HC-C and HC-L). BHCs commitments in the FR Y-9C total nearly $\$ 4.6$ trillion. Thus, our data from the FR Y-14Q accounts for nearly 70 percent of all C\&I equivalent lending in the U.S. ${ }^{26}$

The FR Y-14Q information on the financial health of the borrowers (firm balance sheet and income statement variables) is an invaluable source of information for private firms in the U.S. as this information does not exist anywhere else. ${ }^{27}$ The data also contains borrower

\footnotetext{
${ }^{24} \mathrm{~A}$ credit facility is defined as a credit extension to a legal entity under a specific credit agreement, basically a loan contract.

${ }^{25}$ We keep loans identified on the FR Y-9C as C\&I loans domiciled in the U.S. (item 4(a)), loans to finance agricultural production (item 3), loans secured by owner-occupied real estate domiciled in the U.S. (item $1(\mathrm{e})(1)$ ), and other leases (item 10(b)).

${ }^{26}$ The comparisons between FR Y-14Q and FR Y-9C are not one-to-one and are complicated by at least three factors: 1) HC-C only reports utilized exposures; 2) the committed exposures reported on HC-L are aggregated differently and include loans that are not necessarily U.S. C\&I loans. For example, HC-L reports total committed exposure for all C\&I loans (Y-9C item 4), which includes loans to foreign addresses (item 4(b) in addition to those those domiciled in the U.S (item 4(a)). In addition, the HC-L reports the total committed amount of loans secured by real-estate (item 1), which includes various types of loans secured by real estate in addition to loans secured by owner-occupied real estate domiciled in the U.S. (item 1(e)(1)). 3) FR Y-14Q data only includes loans over $\$ 1 \mathrm{mn}$. Therefore, FR Y-14Q comparisons of the total committed loans amounts to FR Y9-C represent lower bounds of the overall amount of C\&I lending done in the U.S.

${ }^{27} \mathrm{Few}$ commercial data providers, such as, Moody's ORBIS and D\&B provide some of this data but for a select set of private firms that volunteer the information. Other sources such as FED's small business finance
} 
identifiers such as tax identification numbers, CUSIPS, and company names and addresses. These firm identifiers allow us to match the data with other data sources to cross-check information and determine the relative importance of different sets of borrowers e.g. public versus private companies, SMEs versus large firms, and syndicated versus non-syndicated loans.

Bank Holding Companies subject to CCAR. The bank holding companies included in the sample are: beginning in Q3:2011 Ally Financial, Bank of America Corporation, BB\&T Corporation, Bank of New York Mellon Corporation, Citigroup Incorporated, Capital One Financial Corporation, Fifth Third Bancorp, Goldman Sachs Group Incorporated, JPMorgan Chase \& Co., Keycorp, Morgan Stanley, PNC Financial Services Group Incorporate, Regions Financial Corporation, Suntrust Banks Incorporated, State Street Corporation, U.S. Bancorp, Wells Fargo \& Company. Beginning in Q3:2012 Comerica Incorporated, Huntington Bancshares Incorporated, HSBC North America Holdings Incorporated, M\&T Bank Corporation, Northern Trust Corporation, RBC USA Holdco Corporation, Santander Holdings USA Incorporated, UnionBanCal Corporation (renamed to MUFG Americas Holding Corporation in Q3:2014), Zions Bancorporation. Beginning in Q2:2014 Discover Financial Services. Beginning in Q4:2014 BNP Paribas.

HFI, HFS, and Trading Assets. HFS loans and leases are also distinct from loans held on the trading book for market making purposes and subject to different different regulatory capital requirements. Specifically, loans and leases in the trading book are reported on a separate schedule (other than Schedule H1) and typically meet the following trading activities: a) regularly under-writing or dealing in securities; interest rate, foreign exchange rate, commodity, equity, and credit derivative contracts; other financial instruments; and other assets for resale, (b) acquiring or taking positions in such items principally for the purpose of selling in the near term or otherwise with the intent to resell in order to profit from short-term price movements, and (c) acquiring or taking positions in such items as an accommodation to customers or for other trading purposes.

Data Cleaning and Sample Construction. This section describes the intensive data cleaning process needed to use the FR Y14 data for our purposes.

survey and U.S. Census Bureau's QFR data sets are also for select set of firms and not representative of the U.S. economy. See Dinlersoz, Kalemli-Ozcan, Hyatt, and Penciakova (2018) that goes details of the selection problems in the financial data for private firms in the U.S. and how to use U.S. Census Bureau LBD data to correct for this selection. 
1. Remove from the raw loan-level data loans issued to "Individuals" and loans to foreign addresses.

2. Remove any loans to financial firms (NAICS 52); real estate REITS (NAICS 513); educational servies (NAICS 611); religious, grantmaking, and civil and professional organizations (NAICS 813); and private household (NAICS 814).

3. Drop all observations for which there is no financial data reported and when total firm assets are missing or equal to 0.

4. Drop all facilities where the total value of commitments is less than $\$ 1$ million (probable errors given reporting threshold).

5. To consistently identify firms across banks with missing or different tax ids, we first apply a name cleaning algorithm to make a consistent names for firms that are the same based on string matches, zipcode, and city. For example Firm A LLC, 20002 Washington D.C, Firm A Limited Liability Corporation 20002 Washington D.C., and Firm a LLC, 20002 Washington D.C. are all treated as the same firm, etc.

6. Once we have a clean and uniform set of firm names, we can fill in missing tax ids. For observations loans where firm tax id is missing, we fill in missing observations if the bank reports a consistent tax id through any portion of the loan; for multi-bank borrowers for which one bank does not report the tax id, we use a consistent tax id reported by other banks.

7. To ensure that firm income statement and balance sheet variables are reasonable and reported in consistent units, we apply a cleaning algorithm that searches for large reporting discrepancies within and across banks over time for the same firm. We set threshold for potential misreported to be a difference in a variable either by the same bank or across different banks of either $10^{3}, 10^{6}, 10^{9}$ since these are most common unit differences reported in the data. We also note that when there is miss reporting, all variables appear to be consistently miss reported in the same way, so financial ratios are correct.

Internal Consistency of Balance Sheet Information. We follow Gopinath, KalemliOzcan, Karabarbounis, and Villegas-Sanchez (2017) to check the sensibility of our cleaning procedure by comparing the sum of variables belonging to some aggregate of their respective category: 
1. The sum of tangible fixed assets, intangible fixed assets, and other fixed assets as a ratio of total fixed assets.

2. The sum of fixed assets and current assets as a ratio of total assets

3. The sum of long-term debt and other non-current liabilities as a ratio of total non-current liabilities

4. The sum of cash and securities, inventory, and accounts receivable as a ratio of current assets

5. The sum of current assets and tangible assets as a ratio of total assets

6. The sum of accounts payable, short-term debt, and current maturity long-term debt as a ratio of current liabilities

7. The sum of current liabilities, long-term debt and minority interest as a ratio of total liabilities

8. The sum of total liabilities, retained earnings, and capital expenditure as a ratio of total assets.

Information on credit facilities and reporting thresholds in FR Y-14. A credit facility is defined as any legally binding credit extension to a legal entity under a specific credit agreement. A credit facility may be secured or unsecured, term or revolving, drawn or undrawn (excluding informal advised lines). There is no materiality threshold for securities reporting at the individual obligor level. BHCs must report their securities holdings if the entire portfolio is greater than either $\$ 5$ billion or five percent of Tier 1 capital on average for the four quarters preceding the reporting quarter.

Note on Total Liabilities: Flow of Funds. Total non financial corporate liabilities reported by the Flow of Funds in the National Accounts of the U.S. (Table B.3, Series i.d. FL104190005.Q) is computed as

$$
\text { Liabilities }_{\text {total }}=\text { taxes }+ \text { debtsecurities }+ \text { loans }+ \text { miscellaneous }+ \text { FDI. }
$$

The following source the total liability components:

- Tax data come from Internal Revenue Service, Statement Of Income - This item is smallest line item in the total; 
- Debt securities are bond data is from Mergent Fixed Income Securities Database;

- Loan data are pulled from bank call reports - These data are all U.S. chartered bank depository institutions plus foreign bank offices in the U.S. These data also include credit unions;

- Miscellaneous is a catchall category and is the largest single component. This data is the sum of private pension fund contributions from the Department of Labor, and an unidentified category, which is the largest component of miscellaneous. The unidentified category is computed as a residual category from the IRS SOI and flow of founds:

$$
\text { unidentified }=\text { total }_{\text {assets }}-\text { equity }- \text { liabilities },
$$

where liabilities are the individual liability sub-components in the Flow of Funds;

- FDI comes from BEA 


\section{Robustness Appendix}

\section{C.1 Tables}

Table 21: Total Leverage: Public Firms

\begin{tabular}{lccc}
\hline & Quantity: $\log ($ Loan $)$ & Price: & $\log (\mathbf{1}+i)$ \\
& $(1)$ & & $(2)$ \\
\hline High Total Leverage Firm $\times$ MP Suprise $_{q}$ & $0.6014^{* *}$ & & -0.0006 \\
& $(0.2078)$ & & $(0.0042)$ \\
\hline Observations & 322055 & 213531 \\
Adjusted $R^{2}$ & 0.837 & 0.747 \\
Bank $\times$ Firm F.E. & Yes & & Yes \\
Bank $\times$ Quarter F.E. & Yes & & Yes \\
\hline
\end{tabular}

Note: ${ }^{+} p<0.1,{ }^{*} p<0.05,{ }^{* *} p<0.01,{ }^{* * *} p<0.001$. This table presents the results of OLS regressions for bank-firm pairs at a quarterly frequency for the public firms sample. The dependent variable in column (1) is the natural logarithm of the total committed loan amount for a bank-firm pair; the dependent variable in columns (2) is the natural logarithm of one plus the nominal interest rate weighted for loan shares for a given bank-firm pair. Total Firm Leverage is based on short-term and long-term debt and it is 1 when the firm is above the median total leverage of the sample and it is zero otherwise. Double-clustered standard errors by firm and time are reported in parentheses. 
Table 22: Pledged Collateral Within Sectors: Private Firms

\begin{tabular}{|c|c|c|c|c|c|c|}
\hline Sector & Real Estate & $\begin{array}{c}\text { Cash and Marketable } \\
\text { Securities }\end{array}$ & $\begin{array}{c}\text { Accounts Receivable } \\
\text { and Inventory }\end{array}$ & Fixed Assets & $\begin{array}{l}\text { Blanket Lien } \\
\text { and Other }\end{array}$ & Unsecured \\
\hline Accomodation and Food & 10.77 & 7.08 & 11.75 & 4.79 & 53.60 & 12.01 \\
\hline Agriculture & 4.45 & 1.06 & 37.53 & 8.60 & 37.03 & 11.33 \\
\hline Arts and Entertainment & 12.95 & 4.19 & 20.79 & 7.18 & 45.43 & 9.46 \\
\hline Construction & 6.71 & 3.73 & 24.35 & 12.76 & 33.83 & 18.63 \\
\hline Educational Services & 16.17 & 0.41 & 4.83 & 14.43 & 34.25 & 29.92 \\
\hline Healthcare & 29.07 & 3.35 & 18.40 & 6.01 & 33.39 & 9.78 \\
\hline Information & 2.70 & 3.68 & 19.51 & 4.19 & 34.14 & 35.78 \\
\hline Management & 11.31 & 14.24 & 11.56 & 4.57 & 26.86 & 31.47 \\
\hline Manufacturing & 4.67 & 1.70 & 33.33 & 7.45 & 32.97 & 19.89 \\
\hline Mining and Gas Extraction & 1.47 & 2.41 & 30.78 & 9.35 & 44.35 & 11.64 \\
\hline Other Services & 21.23 & 2.97 & 23.83 & 5.58 & 35.55 & 10.83 \\
\hline Professional, Science and Technology & 5.21 & 2.72 & 28.29 & 3.67 & 35.06 & 25.04 \\
\hline Public Administration & 0.00 & 1.67 & 36.40 & 0.64 & 33.55 & 27.75 \\
\hline Real Estate & 5.53 & 1.43 & 26.84 & 27.95 & 28.63 & 9.63 \\
\hline Retail and Trade & 9.16 & 2.53 & 61.17 & 3.17 & 17.08 & 6.88 \\
\hline Transportation and Warehousing & 5.64 & 1.32 & 18.38 & 29.01 & 29.13 & 16.52 \\
\hline Utilities & 1.08 & 4.83 & 6.30 & 5.56 & 27.45 & 54.79 \\
\hline Waste Management Administration & 3.68 & 2.59 & 30.30 & 6.69 & 44.53 & 12.22 \\
\hline Wholesale Trading & 4.39 & 1.43 & 43.57 & 4.26 & 32.29 & 14.06 \\
\hline Average & 8.22 & 3.33 & 25.68 & 8.73 & 34.69 & 19.35 \\
\hline
\end{tabular}


Table 23: Pledged Collateral Within Sectors: Public Firms

\begin{tabular}{|c|c|c|c|c|c|c|}
\hline Sector & Real Estate & $\begin{array}{c}\text { Cash and Marketable } \\
\text { Securities }\end{array}$ & $\begin{array}{l}\text { Accounts Receivable } \\
\text { and Inventory }\end{array}$ & Fixed Assets & $\begin{array}{l}\text { Blanket Lien } \\
\text { and Other }\end{array}$ & Unsecured \\
\hline Accomodation and Food & 3.69 & 6.05 & 8.16 & 1.71 & 23.64 & 56.74 \\
\hline Agriculture & 0.96 & 0.04 & 2.00 & 1.18 & 2.80 & 93.03 \\
\hline Arts and Entertainment & 0.70 & 4.97 & 35.13 & 2.13 & 52.30 & 4.77 \\
\hline Construction & 0.59 & 3.72 & 18.61 & 5.01 & 25.67 & 46.41 \\
\hline Educational Services & 0.00 & 0.00 & 3.97 & 0.00 & 0.00 & 96.03 \\
\hline Healthcare & 1.45 & 6.57 & 27.71 & 3.40 & 35.03 & 25.85 \\
\hline Information & 0.39 & 2.24 & 7.62 & 1.45 & 13.65 & 74.64 \\
\hline Management & 0.01 & 18.46 & 4.84 & 0.67 & 8.53 & 67.50 \\
\hline Manufacturing & 0.39 & 1.59 & 9.73 & 1.95 & 14.35 & 72.00 \\
\hline Mining and Gas Extraction & 0.32 & 1.14 & 13.63 & 2.59 & 23.97 & 58.36 \\
\hline Other Services & 0.56 & 3.58 & 9.64 & 3.59 & 19.08 & 63.56 \\
\hline Professional, Science and Technology & 0.67 & 2.51 & 19.15 & 1.79 & 26.51 & 49.38 \\
\hline Public Administration & 0.00 & 4.74 & 0.00 & 0.00 & 71.11 & 24.15 \\
\hline Real Estate & 1.37 & 1.47 & 16.75 & 18.93 & 20.84 & 40.63 \\
\hline Retail and Trade & 0.76 & 0.53 & 18.78 & 3.46 & 11.68 & 64.78 \\
\hline Transportation and Warehousing & 0.65 & 1.99 & 9.52 & 8.18 & 15.61 & 64.05 \\
\hline Utilities & 0.35 & 2.10 & 0.63 & 2.44 & 9.99 & 84.50 \\
\hline Waste Management Administration & 0.74 & 1.90 & 17.28 & 2.18 & 19.72 & 58.17 \\
\hline Wholesale Trading & 1.00 & 2.01 & 21.48 & 2.61 & 19.03 & 53.87 \\
\hline Average & 0.77 & 3.45 & 12.87 & 3.33 & 21.76 & 57.81 \\
\hline
\end{tabular}

Table 24: Fraction of Loan Commitments by Collateral Type and Decile of Assets

\begin{tabular}{lcccccccccc}
\hline & \multicolumn{1}{c}{ Decile based on Assets } \\
\cline { 2 - 11 } Category & 1 & 2 & 3 & 4 & 5 & 6 & 7 & 8 & 9 & 10 \\
\hline Real Estate & 44 & 18 & 11 & 8 & 7 & 5 & 4 & 2 & 1 & 0 \\
Cash and Marketable Securities & 2 & 3 & 3 & 2 & 2 & 2 & 2 & 3 & 3 & 1 \\
Accounts Receivable and Inventory & 12 & 26 & 40 & 45 & 48 & 45 & 40 & 34 & 24 & 09 \\
Fixed Assets excluding Real Estate & 6 & 9 & 8 & 8 & 8 & 8 & 8 & 6 & 5 & 3 \\
Blanket Lien and Other & 32 & 40 & 36 & 32 & 32 & 34 & 37 & 33 & 23 & 12 \\
Unsecured & 3 & 3 & 3 & 3 & 3 & 5 & 10 & 21 & 44 & 73 \\
\hline
\end{tabular}

Note: Decile based on Assets. Numbers are in percentage terms. 


\title{
C.2 Figures
}

Figure 21: Share of Bank Debt in Non-Financial Private Firms' Financing in FR Y-14

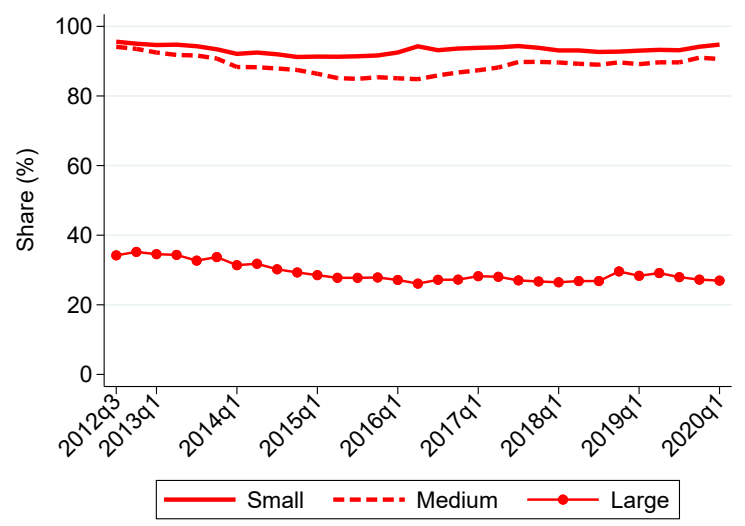

Note: The figures plot the median loan commitment as share of total balance sheet debt for various points in the asset-size distribution among private borrowers. Source: FR-Y14Q H.1

Figure 22: Collateral Types among SMEs

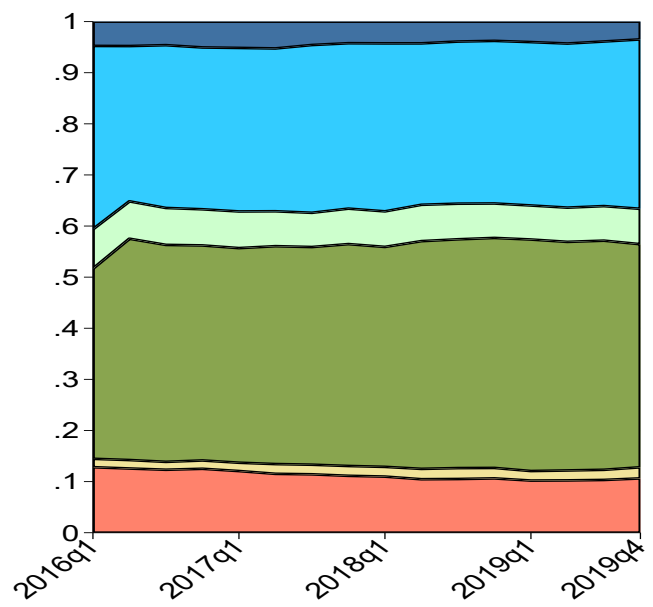

\author{
Unsecured \\ $\square$ Blanket Lien + Other \\ $\square$ Fixed Assets \\ $\square$ Accounts Receivable and Inventory \\ $\square$ Cash and Marketable Securities \\ $\square$ Real Estate
}

Note: The figure plots loan values secured by different collateral types over time for SME borrowers. SMEs are defined as firms with annual sales less than $\$ 50 \mathrm{mn}$. The different types of collateral are real estate collateral (salmon); cash and marketable securities (yellow); accounts receivable, inventory (green); fixed assets (mint); blanket liens and other (light blue); and unsecured (dark blue). Source: FR Y14-Q H.1. 
Figure 23: Collateral Type: Public vs. Private (Based on Number of Loans)

Small Private

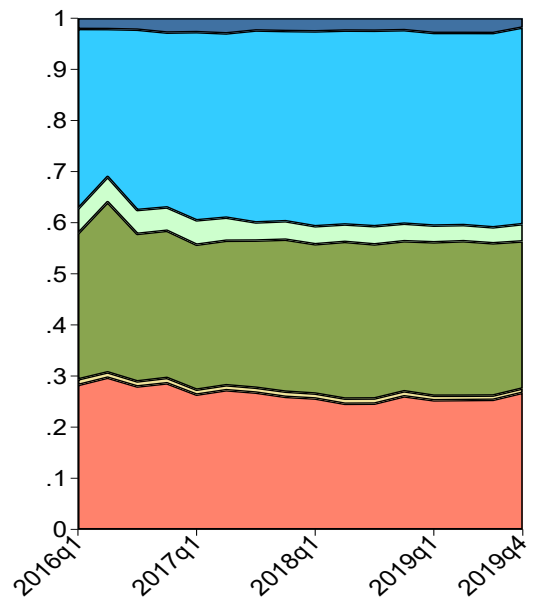

Small Public

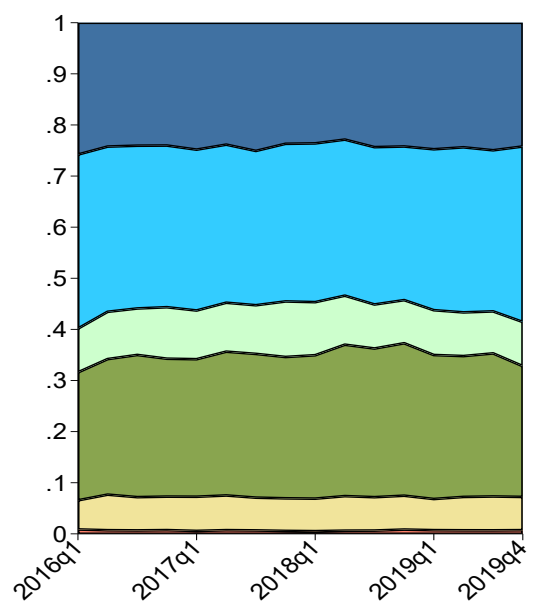

Medium Private

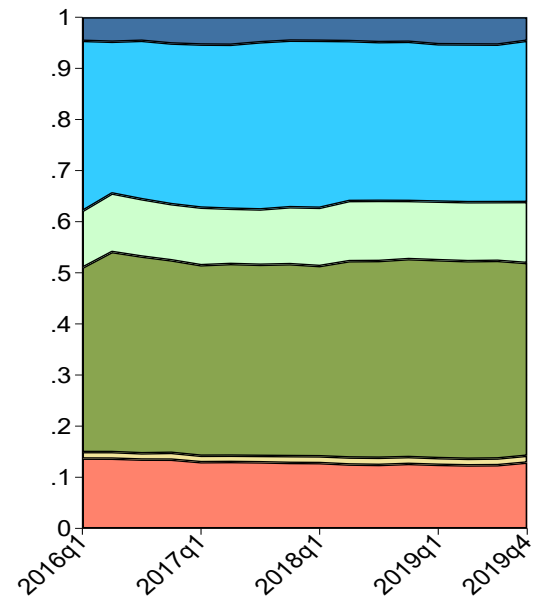

Medium Public

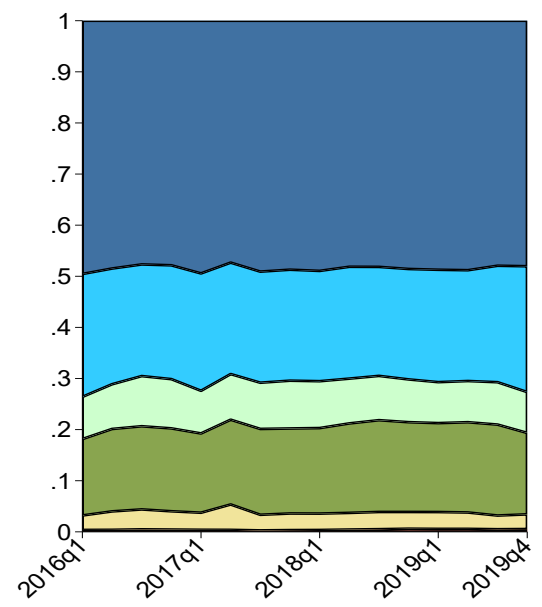

$\square$ Unsecured

$\square$ Blanket Lien + Other

$\square$ Fixed Assets

$\square$ Accounts Receivable and Inventory

$\square$ Cash and Marketable Securities

$\square$ Real Estate
Large Private

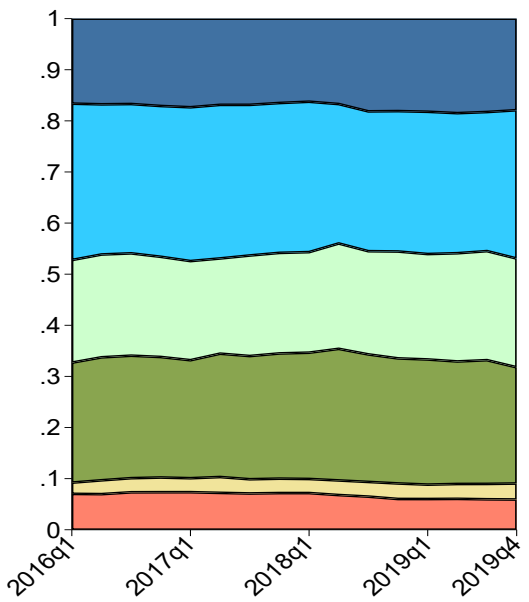

Large Public

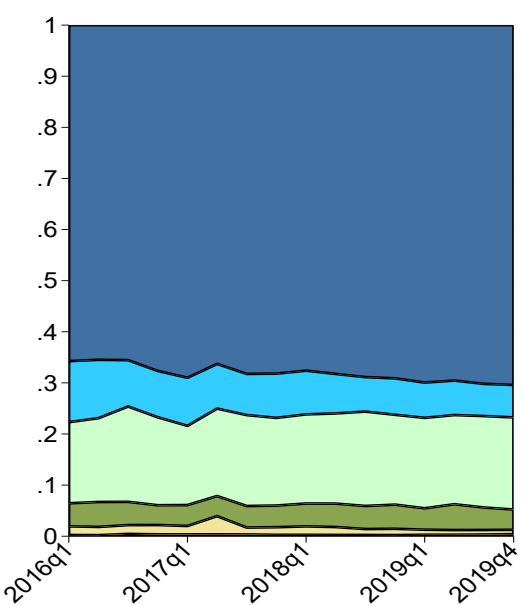

Note: The figure plots the proportion of loans secured by different collateral types over time. The different types of collateral are cash and marketable securities (in yellow); accounts receivable, inventory (in dark green); blanket liens (in light blue); fixed assets (in light green); real estate (in orange); and unsecured loans (in dark blue). The top three panels from left to right show the proportion of loans secured by the different collateral types and unsecured for private borrowers in the bottom quartile of assets (small), between the bottom and top quartile of assets (medium), and above the top quartile of assets (large). The bottom three panels present the same information for public borrowers. Source: FR Y14-Q H.1. 


\section{Figure 24: Loan shares: Credit Lines/Term loans and Floating/Fixed Rates}

Credit Line

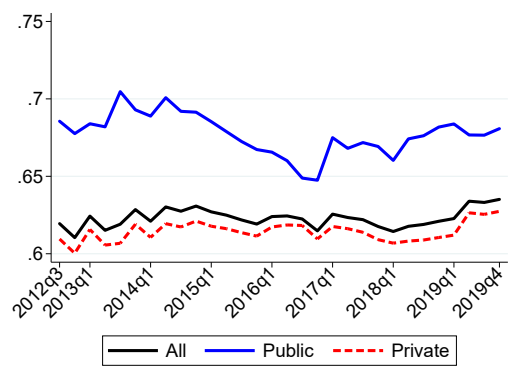

Term Loans

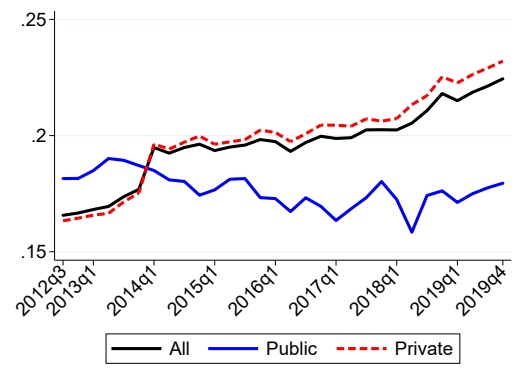

Float Rate

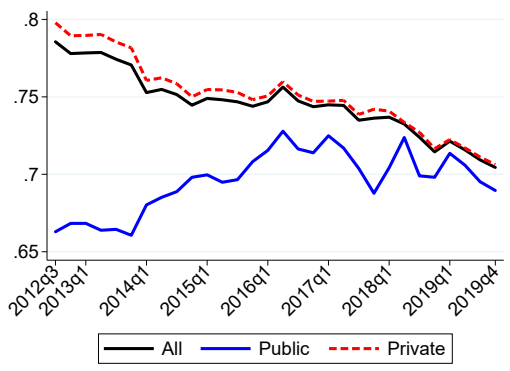

Note: The share of credit lines among all loan types in the left panel. The middle panel plots the term loans shares. The right panel plots the share of loans with floating interest rates. Source: FR Y-14Q H.1. Source: FR Y-14Q H.1. 